\title{
Literature review labour migration
}

Citation for published version (APA):

Cörvers, F., Reinold, J., Chakkar, S., Bolzonella, F., \& Ronda, V. (2021). Literature review labour migration. ROA. ROA Technical Reports No. 005ROA External Reports Vol. WODC rapport No. 3248 https://doi.org/10.26481/umarot.2021005

Document status and date:

Published: 30/08/2021

DOI:

10.26481/umarot.2021005

Document Version:

Publisher's PDF, also known as Version of record

\section{Please check the document version of this publication:}

- A submitted manuscript is the version of the article upon submission and before peer-review. There can be important differences between the submitted version and the official published version of record.

People interested in the research are advised to contact the author for the final version of the publication, or visit the DOI to the publisher's website.

- The final author version and the galley proof are versions of the publication after peer review.

- The final published version features the final layout of the paper including the volume, issue and page numbers.

Link to publication

\footnotetext{
General rights rights.

- You may freely distribute the URL identifying the publication in the public portal. please follow below link for the End User Agreement:

www.umlib.nl/taverne-license

Take down policy

If you believe that this document breaches copyright please contact us at:

repository@maastrichtuniversity.nl

providing details and we will investigate your claim.
}

Copyright and moral rights for the publications made accessible in the public portal are retained by the authors and/or other copyright owners and it is a condition of accessing publications that users recognise and abide by the legal requirements associated with these

- Users may download and print one copy of any publication from the public portal for the purpose of private study or research.

- You may not further distribute the material or use it for any profit-making activity or commercial gain

If the publication is distributed under the terms of Article $25 \mathrm{fa}$ of the Dutch Copyright Act, indicated by the "Taverne" license above, 


\section{Maastricht University}

\section{Literature review labour migration}

An exploratory study into the shortages of qualified personnel at the upper secondary vocational level and the possibilities and limitations of employing migrants

Frank Cörvers (ROA)

Julia Reinold (UNU-MERIT)

Saena Chakkar (ROA)

Francesco Bolzonella (ROA)

Vera Ronda (UNU-MERIT)

\section{ROA Technical Report}

ROA-TR-2021/5

Researchcentrum voor Onderwijs en Arbeidsmarkt | ROA Research Centre for Education and the Labour Market / ROA 


\title{
Literature review labour migration
}

An exploratory study into the shortages of qualified personnel at the upper secondary vocational level and the possibilities and limitations of employing migrants

\author{
Frank Cörvers (ROA) \\ Julia Reinold (UNU-MERIT) \\ Saena Chakkar (ROA) \\ Francesco Bolzonella (ROA) \\ Vera Ronda (UNU-MERIT)
}

ROA-TR-2021/5

June 2021

Research Centre for Education and the Labour Market

Maastricht University

P.O. Box 616, 6200 MD Maastricht, The Netherlands

$\mathrm{T}+31433883647 \mathrm{~F}+31433884914$

secretary-roa-sbe@maastrichtuniversity.nl

www.roa.nl

(c) WODC

ISSN: 2666-884X 


\section{Maastricht University $\quad$ ROA}

UNITED NATIONS

UNIVERSITY

\section{UNU-MERIT}

Maastricht University

Institute for Transnational and Euregional cross border cooperation and Mobility / ITEM

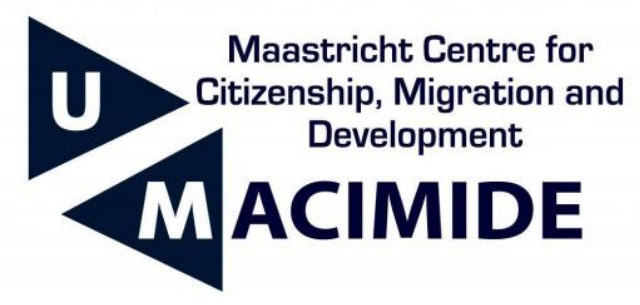

1) Maastricht University

Maastricht Graduate School of Governance

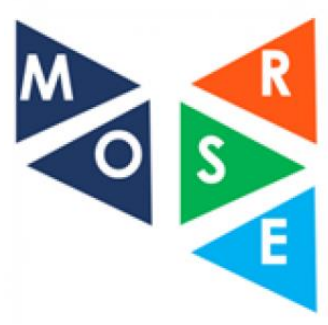




\section{Table of Contents}

Table of Contents 1

List of abbreviations 2

Acknowledgements $\quad 5$

Executive Summary 6

$\begin{array}{ll}\text { Samenvatting } & 14\end{array}$

1. Introduction 24

2. Methodology 28

3. Shortages and skill requirements in the middle segment of the Dutch labour market 31

3.1 Identification of focus sectors and most important skill shortages 31

3.2 Required background characteristics and skills for workers in the focus sectors 36

4. Priority supply from EEA+ countries and beyond 45

4.1 Labour shortages and oversupply in EEA+ countries 45

4.2 Supply of EEA+ nationals 46

4.3 Supply of TCNs from EEA+ countries $\quad 49$

4.4 Migration to the Netherlands 51

4.5 Why do the Dutch demand and foreign supply not match? 56

5. Migration as a solution to address shortages in the middle segment of the Dutch labour market

5.1 European Union Law on Migration $\quad 59$

5.2 Available Dutch migration policy tools $\quad 65$

5.3 The role of the assessment of foreign qualification, knowledge and skills 69

5.4 What can be learnt from other countries? 73

$5.5(\mathrm{Im})$ possibilities for labour migration policy $\quad 76$

6. Alternative solutions to staffing bottlenecks in the middle segment of the Dutch labour market $\quad 82$

6.1 National and firm strategies to tackle skills shortages 82

6.2 Strategies to tackle skills shortages in the three focus sectors 85

7. Conclusions and directions for further research 98

$\begin{array}{ll}\text { References } & 103\end{array}$

$\begin{array}{ll}\text { Annex 1: Search terms } & 128\end{array}$

Annex 2: Future technical and green skills in the Machine tool industry 129 


\section{List of abbreviations}

\begin{tabular}{|c|c|}
\hline$A C V Z$ & $\begin{array}{l}\text { Dutch Advisory Committee on Migration Affairs (Adviescommissie voor } \\
\text { Vreemdelingenzaken) }\end{array}$ \\
\hline AIS & Labour Market Information System (Arbeidsmarktinformatiesysteem) \\
\hline AKV-toets & $\begin{array}{l}\text { General knowledge and skills test (Algemene Kennis- en } \\
\text { Vaardighedentoets) }\end{array}$ \\
\hline Bl-toets & Professional test (beroepsinhoudelijke toetsing) \\
\hline $\mathrm{BIG}$ & $\begin{array}{l}\text { Professions in individual healthcare (Beroepen in de Individuele } \\
\text { Gezondheidszorg) }\end{array}$ \\
\hline BZEE & German Training Center for Renewable Energies \\
\hline CBS & Statistics Netherlands (Centraal Bureau voor de Statistiek) \\
\hline CBGV & Commission for Foreign Healthcare Graduates \\
\hline CEDEFOP & European Centre for the Development of Vocational Training \\
\hline $\mathrm{CMI}$ & Construction, manufacturing, and installation \\
\hline CSP & Concentrated Solar Power \\
\hline EASME & Executive Agency for Small and Medium-sized Enterprises \\
\hline ECLAC & $\begin{array}{l}\text { United Nations Economic Commission for Latin America and the } \\
\text { Caribbean }\end{array}$ \\
\hline EE & Energy efficiency \\
\hline EEM & Energy-efficient measures \\
\hline EEA & European Economic Area (EER, Europese Economische Ruimte) \\
\hline EEA+ & European Economic Area plus Switzerland \\
\hline EFTA & European Free Trade Association \\
\hline ESSA & European Steel Skills Agenda and Strategy \\
\hline EU & European Union \\
\hline EURES & European cooperation network of employment services \\
\hline FQR & Foreign Qualification Recognition \\
\hline GVVA & $\begin{array}{l}\text { Combined work and residence permit (gecombineerde vergunning tot } \\
\text { verblijf en arbeid) }\end{array}$ \\
\hline $\mathrm{HBO}$ & Higher vocational education \\
\hline $\mathrm{HCA}$ & Healthcare assistant \\
\hline
\end{tabular}




\begin{tabular}{|c|c|}
\hline $\mathrm{HR}$ & Human Resources \\
\hline HVAC & Heating, ventilation, and air conditioning \\
\hline IcDW & Credential Evaluation Information Centre \\
\hline ICT & Information and Communications Technology \\
\hline ILO & International Labour Organisation \\
\hline IOM & International Organisation for Migration \\
\hline ISCED & International Standard Classification of Education \\
\hline LTR & Long-term residents \\
\hline MBO & Intermediate vocational education \\
\hline MMC & Modern Methods of Construction \\
\hline MVV & Temporary residence permit (machtiging tot voorlopig verblijf) \\
\hline NACE & National Association of Colleges and Employers \\
\hline NLQF & Dutch framework for qualifications \\
\hline OECD & Organisation for Economic Co-operation and Development \\
\hline O\&M & Operations and maintenance \\
\hline OTA & Operation theatre assistants \\
\hline PBL & $\begin{array}{l}\text { Netherlands Environmental Assessment Agency (Planbureau voor de } \\
\text { Leefomgeving) }\end{array}$ \\
\hline PD & Portable Document \\
\hline PV & Solar Photovoltaic \\
\hline$R \& D$ & Research and development \\
\hline $\mathrm{RE}$ & Renewable Energy \\
\hline ROA & Research Centre for Education and the Labour Market \\
\hline SBB & Foundation for Cooperation on Vocational Education \\
\hline SMEs & Small and medium enterprises \\
\hline STEM & Science, technology, engineering, and mathematics \\
\hline TCN & Third-country national \\
\hline TFEU & Treaty of the Functioning of the European Union \\
\hline
\end{tabular}




\begin{tabular}{|c|c|}
\hline $\mathrm{TI}$ & Technical installation sector \\
\hline TPWind & European Wind Energy Technology Platform \\
\hline TVET & Technical and vocational education and training \\
\hline TWV & Work permit (Tewerkstellingsvergunning) \\
\hline UWV & $\begin{array}{l}\text { Netherlands Employee Insurance Agency, to implement employee } \\
\text { insurances and provide labour market and data services, providing } \\
\text { Public Employment Services (PES) for the Netherlands }\end{array}$ \\
\hline VET & Vocational Education and Training \\
\hline VPL & $\begin{array}{l}\text { Validation of Prior Learning (Erkenning van Verworven Competenties, } \\
\text { EVC) }\end{array}$ \\
\hline WODC & $\begin{array}{l}\text { Research and Documentation Centre (Wetenschappelijk Onderzoek- en } \\
\text { Documentatiecentrum) }\end{array}$ \\
\hline WRTP & Wisconsin Regional Training Partnership \\
\hline VET & Vocational Education and Training \\
\hline
\end{tabular}




\section{Acknowledgements}

The present study was carried out by ROA and UNU-MERIT on behalf of the WODC (Wetenschappelijk Onderzoek- en Documentatiecentrum, i.e. Research and Documentation Centre), the knowledge centre of the Dutch Ministry of Justice and Security. We thank the members of the Advisory board of this project for their support and useful suggestions:

- Dr. Frans Beijaard, senior project manager, Afdeling Extern Wetenschappelijke Betrekkingen (EWB), Wetenschappelijk Onderzoek- en Documentatiecentrum (WODC);

- $\quad$ Dr. Jan Cremers, senior researcher, Tilburg Law School, Tilburg University;

- Rik Rovers LLM, policy coordinator, migration policy department, Ministry of Justice and Security;

- Prof. dr. Helga de Valk (chair), Director of the Netherlands Interdisciplinary Demographic Institute (NIDI) and professor of Migration and the life course at the University of Groningen.

We also thank the experts in our network who provided us with recommendations for further reading (see Section 2 of this report for the expert list).

In the preparation of this report, we were grateful for the support of the various research institutes and networks to which the authors are affiliated:

- The Research Centre for Education and the Labour Market (ROA; www.roa.nl)

- The United Nations University - Maastricht Economic and Social Research Institute on Innovation and Technology (UNU-MERIT; https://www.merit.unu.edu/)

- The Institute for Transnational and Euregional cross border cooperation and Mobility (ITEM; https://www.maastrichtuniversity.nl/item)

- The Maastricht Centre for Citizenship, Migration and Development (MACIMIDE; https://macimide.maastrichtuniversity.nl)

- The Maastricht Graduate School of Governance (MGSoG; https://www.maastrichtuniversity.nl/research/maastricht-graduate-school-governance)

- The Maastricht Observatory on Resilient, Responsible \& Sustainable Enterprise and Economy (MORSE; https://www.maastrichtuniversity.nl/morse) 


\section{Executive Summary}

Attracting and retaining migrants can have many benefits for the host country and its economy, for example to mitigate skills shortages. Regulating immigration may prevent several negative consequences of a shrinking and ageing population. However, research and policy often focus on the highly skilled or so-called knowledge migrants (kennismigranten) as a source of human capital, which can increase innovation and a country's competitiveness. A group of labour migrants that receives significantly less attention from research and policy, are the mediumskilled migrant workers. Although it makes up a significant share of the migrant population, this group is rarely supported by specific migration policies.

Therefore, in this report we would like to answer the following central research question, as formulated by the WODC.

\section{Central research question:}

What is known in available literature about the opportunities and limitations of filling labour shortages through labour migration, especially in the middle segment of the labour market?

The methodology we used for collecting the relevant literature is based on, first, a systematic search for literature based on a predefined set of search terms. We also used the suggestions by the WODC and the Advisory board for this project. We next did a secondary search by the snowballing technique to identify additional literature from the results of the primary search. Additional information was searched to better understand the context about migration to the Netherlands and intra-EU migration, for example statistics and policy documents of websites of relevant Dutch and German government institutions. Finally, we consulted our network of experts.

This report first explores the labour shortages in the middle segment of the Dutch labour market, with a special focus on the metal, energy transition and healthcare sectors, and next discusses the skills requirements and background characteristics of workers per focus sector. The migration part of the report continues with discussing the priority supply in the EEA+ countries and to what extent this matches Dutch labour demand. Next the report addresses migration as a solution to address shortages in the middle segment of the Dutch labour market. In doing so, it reviews relevant European and Dutch legislation on migration as well as the recognition of qualifications. Furthermore, it discusses what can be learnt from Germany and some other countries. Apart from migration, the report also explores to what extent other possible solutions can contribute to solve the identified shortages in the middle segment of the Dutch labour market, in particular for the three focus sectors. Finally, the report concludes with how these solutions relate to the possible role of labour migration policy to tackle bottlenecks on the labour market, and discusses some directions for further research.

More specifically, the report addresses the following sub-questions, which were derived from the above central research question by the WODC. 
Sub-questions:

1. In which sectors of the middle segment of the Dutch labour market are there shortages of employees? Which sectors are included in the study, and why?

2. What are the desired characteristics of the sought-after workers (per sector), such as: demographics, professional education, expertise, skills and/or other?

3. Is there a sufficient priority supply for these workers in the EEA and/or outside the EEA? If so, which supply and where; why do the Dutch demand and the foreign supply not match?

4. Which instruments can play a role in bringing the Dutch demand and the foreign supply together? Where do the opportunities and limitations lie in this respect / possibilities and impossibilities for labour migration policy?

5. Have other possible solutions been mentioned for the identified shortages in the middle segment of the Dutch labour market? If so, which?

6. How do the opportunities and limitations/ possibilities and impossibilities of the instruments relate to each other, especially for the possible role of labour migration policy?

Where relevant in this report, we will also address the expected impact of the COVID-19 pandemic on the validity of the findings. The summaries of the answers to the sub-questions are given below.

Sub-question 1: In which sectors of the middle segment of the Dutch labour market are there shortages of employees? Which sectors are included in the study, and why?

Answer:

- Based on an analysis of the largest staffing bottlenecks for employers up to 2024, it can be concluded which sectors of industry would benefit most from a supportive migration policy aimed at the middle segment of the labour market. This middle segment comprises all persons who have obtained their diploma at the level of upper secondary vocational education, i.e. at mbo 4-level.

- The following three sectors face the largest labour market shortages at this education level: metal industry, energy transition (including construction and energy) and (health)care. These sectors are called the focus sectors throughout this report.

- There is quite some overlap between the metal and energy transition sectors (energy and construction) with respect to the most prominent shortage occupations and types of education in the middle segment of the three focus sectors. Within these sectors, the broad key occupations Maintenance and installation engineers, Electricians and electronics mechanics, Technicians in construction and nature are likely to face large staffing bottlenecks up to 2024. The same holds for the mbo 4-level types of education in these sectors: Mechanical engineering and metalworking, Electrical and installation engineering, Construction and infrastructure.

- Furthermore, within the broad shortage occupations of the metal and energy transition sectors, specific occupations can be distinguished for which employers now face large staffing bottlenecks. In the short run, this situation is likely to continue for these occupations.

- In contrast to the metal sector and the energy transition sector, in the healthcare sector nurses are the only key occupation in the middle segment of the labour market with 
large staffing bottlenecks. This occupation is related to the mbo 4-level education nursing and medical support. Nurses are more or less equally employed in the care and the welfare sector. Some specialisation is possible at the mbo 4-level, although for real specialisation further education at bachelor level is required.

Sub-question 2: What are the desired characteristics of the sought-after workers (per focus sector), such as: demographics, professional education, expertise, skills and/or other?

Answer:

- Working in specific technical or care occupations does require specific skills, but our literature review also reveals that more general social or interpersonal and culture or language skills are often as least as important. Migrant workers are clearly underrepresented in the healthcare sector, as well as in the construction sector.

- There are many specific occupations requiring much specialisation in the energy transition sector, which may explain that the required skills (numeracy and problemsolving) skills in the energy sector are above average, contrary to the required skills in the construction sector. Workers In the metal sector typically participate less than average in (long-term) training activities.

- There are many females working in part-time jobs in the healthcare sector, contrary to the metal and energy transition sectors. Young workers (up to 30 years old) are underrepresented in the metal and energy sectors of industry.

- Bear in mind that the above description of the background characteristics of workers and the skill requirements in the focus sectors are mostly not known exactly for employees at mbo 4-level, but largely apply to the average worker per focus sector.

- In addition, the metal sector and in particular the energy transition sector comprise a large number of sub-sectors. Within the metal sector we can distinguish, among other sub-sectors, the steel sector and the machine tool sector. Within the energy transition sector, the variety of subsectors is probably even greater, with, for example, the energy sectors wind, solar, hydropower, bio-energy and the construction sectors technical installation and sustainable construction (among others). Note also that not all economic activities within these sub-sectors are necessarily related to the energy transition.

Sub-question 3: Is there a sufficient priority supply for these workers in the EEA and/or outside the EEA? If so, which supply and where; why do the Dutch demand and the foreign supply not match?

Answer:

\section{Priority supply}

- Skills shortages requiring personal intervention (e.g. healthcare related) as well as technical (STEM: scientific, technological, engineering or mathematical expertise) skills shortages are widespread and severe in the EEA+ countries. Health professions figure more prominently than in previous years; nurses even rank first among occupations with a shortage.

- Although the evidence is scarce, there seems to be hardly any oversupply in the EEA+ countries for the shortage occupations in the Netherlands, including those related to the three focus sectors. It is probably very difficult to recruit from the priority 
supply. We can conclude that it may be necessary to attract workers from third countries to fill the vacancies for these occupations.

\section{Relevance of supply from TCNs}

- Due to the aging population in the EEA+ countries, the supply of potential workers should be sought for outside these areas.

- There is a potential supply in Africa, but this is a relatively 'short-term' solution.

- Facilitating more options for the free movement of current TCNs in EEA+ countries could have a positive impact on their labour demand and supply.

- Strengthening the labour market position of migrant women may also increase supply.

\section{Limitations to matching Dutch demand and foreign supply}

- Within the EEA+ countries, there is hardly any priority supply that matches demand in Dutch shortage occupations (see above).

- European and Dutch migration policies focus on the highly skilled, which is why migration of the medium-skilled is more difficult to realise, even if there is a supply outside the EEA+ countries and even if people are willing to migrate.

- Limited transferability of foreign degrees and qualifications may contribute to underemployment of many migrants in the Netherlands.

Sub-question 4: Which instruments can play a role in bringing the Dutch demand and the foreign supply together? Where do the opportunities and limitations lie in this respect / possibilities and impossibilities for labour migration policy?

Answer:

\section{Available instruments}

- There is no legal instrument available that targets the medium-skilled specifically.

- Medium-skilled migration is possible through various rather restrictive channels.

- The Netherlands has a fragmented migration policy landscape.

\section{Opportunities}

- Migration can be one of the most efficient ways to address skills shortages.

- Migration can lower unemployment in countries of origin and countries of previous residence, e.g. in the case of intra-EEA+ migration of TCNs.

- Migration can rejuvenate the Dutch workforce.

- Posting opens new ways of legal migration.

- Posted workers officially reside and work in one EEA+ country, but are sent to a second EEA+ country to provide a service for a temporary period of time. This can include the hiring out through a temporary work agency (uitzendbureau).

- The posting of TCN workers does not involve any migration requirements on parts of the country to which the worker is posted.

- Circular migration is a form of temporary migration in which an individual repeatedly moves back and forth between two or more countries, usually for the purpose of labour. Circular migration schemes can be seen as a flexible way to mitigate skills shortages and curb irregular migration.

- Circular migration is associated with benefits for migrants themselves, as well as their host and home countries, although these are subject to debate.

\section{Limitations}

- Migration cannot be the only solution to filling skills shortages. 
- Restrictiveness of available instruments and lengthy procedures make it difficult to respond to shortages.

- Migration is very much dependent on employers, who often prefer alternative solutions to recruiting migrants, e.g. due to remaining prejudices and stereotypes.

- The procedures for the recognition of foreign qualifications are expensive and lengthy.

- Employers can (ab)use posting to save labour costs.

- More specific information on the trends and dynamics of posted work to the Netherlands is scarce and we could not identify any literature that covers the posting of TCNs working in the three focus sectors.

\section{Possibilities}

- It could be possible to improve the free movement of TCNs through the expansion of the Single Permit Directive.

- There are possibilities to introduce a migration policy specifically aimed at the medium-skilled level, like the Skilled Workers Immigration Act in Germany.

- The relatively new Skilled Workers Immigration Act in Germany (in effect as of March 2020) establishes access to certain occupations for non-EEA+ migrants with intermediate qualifications, enables them to find work in Germany, facilitates skills development and shortens processing times.

- A standing committee could investigate labour demand and supply, and the opportunities for labour migrants to meet excess demand.

- Sectoral policies could be created to address labour market shortages.

- Mobility partnerships (including vocational training policies) could be created to expand transnational cooperation for the recruitment of medium-skilled workers.

- More liberal migration policies targeting all migrants disregarding their educational or skills level and occupation could be copied from Sweden; this could also prevent the creation of an even more fragmented labour migration landscape.

- Increasing the awareness of benefits of migration among employers and the general public could further help to increase the recruitment of medium-skilled workers.

- The phenomenon of posting does concern Eastern European workers as well as a large share of posted workers coming from Western EU Member States being posted to other Western EU Member States. TCNs with a valid work and residence permit in one EEA+ country can also be posted across the EEA+.

- Intra-EEA+ posting of TCN workers is on the increase and this mainly concerns lowand medium-skilled workers.

\section{Impossibilities}

- It is not sufficient to design migration policies to attract medium-skilled workers, it is also important to integrate them into Dutch society.

- Although there are some indications that the Skilled Workers Immigration Act has been successful in fostering a higher influx of skilled migrants to Germany, the recognition requirement could be a major hurdle.

- The Swedish system can be a good example for the Netherlands. It has proven to be effective, although there are still some shortcomings, such as the abuse of migrant workers.

Different procedures are in place for Foreign Qualification Recognition as an instrument to bring the Dutch demand and the foreign supply together in the three focus sectors

- The procedure for recognition of professional qualifications applies to those with a non-automatically recognised qualification obtained in a non-EEA+ country.

- Firstly, getting the qualifications recognised in healthcare occupations can be quite a lengthy process, especially for holders of degrees from outside the 
EEA+ countries. The recognition procedures turn out to be complex and often poorly understood by TCNs, making identifying recognition options, pathways and alternatives challenging.

- Secondly, there is a high dropout rate in the process.

- For the metal and energy transition sectors, there are no regulated occupations on mbo level-4 for which qualification recognition is mandatory. Relevant for migrants who want to work in unregulated occupations is foreign credential evaluation. This can give a good indication of the value of a foreign diploma in the Netherlands and can be used both for finding fitting employment and finding a suitable study.

- A last type of recognition is the so-called validation of prior learning (VPL, in Dutch Erkenning van Verworven Competenties, EVC). The value of the VPL highly depends on employers and educational institutes endorsing and accepting the VPL certificates. This policy instrument falls under the strategy of lifelong learning. VPL can be used for two routes:

- In the labour market route, prior learning outcomes of individuals are validated against sector or organisation standards.

- For the education route of VPL, applicants validate their formally/informally/non-formally acquired competences as a step to obtaining a formal qualification.

Sub-question 5: Have other possible solutions been mentioned for the identified shortages in the middle segment of the Dutch labour market? If so, which? Answer:

\section{General findings on bottleneck solutions}

- Strategies to cope with skills shortages and to overcome staffing bottlenecks require both comprehensive policy adjustments at the national level and targeted HR policies within firms.

- At the national level, various successful approaches have been taken to better match labour supply and demand in order to encourage people to study and work in specific areas with obvious shortages, such as STEM, ICT and R\&D.

- There is ample evidence that tailored approaches to human resource management and development have helped to marginalise the negative effects of skill shortages.

- The use of different recruitment channels (such as employment agencies and other intermediaries, cross-border postings) can also be helpful in filling vacancies.

- On the demand side: Compensation, recruitment parameters and job structuring are components of a skills gap strategy.

- On the supply side: Strategies aimed at offering new training courses or designing new training programmes, and strategies to reduce institutional barriers by introducing more efficient education, training and recruitment arrangements.

- It is important to give workers a T-shape set of necessary skills to move easily from one speciality to another.

- It should be noted that these strategies are usually not specific to the middle segment of the labour market, apart from measures that can be taken to improve the vocational training and education (VET) system and promote the recruitment of (VET) apprentices. 


\section{Findings for the three focus sectors to tackle staffing bottlenecks}

- Metal sector

- In-house training for a T-shaped skill set

- Advancing human resource strategies

- Tap into disadvantaged labour segments

- Intensify cooperation and staff exchange with education institutes

- Strengthen the capacity of Public-Private Partnerships

- Targeted training subsidies to small enterprises

- Following the trend of automatisation: Adapting to technological change

- Energy transition sector (examples from three subsectors)

- Wind energy industry

- Promotion of shorter and flexible vocational training courses

- Promotion of collaboration between industry and academics

- Encouraging more industry input into academic courses in the relevant discipline

- Harmonisation of VET in the European context

- A well-planned national education and training strategy

- Set up investment programmes together with other employers, such as dual education systems

- Transnational networks may allow the acceptance of qualifications issued by institutions abroad to facilitate international mobility

- Technical installation (TI) industry

- Recruitment of staff from outside the TI industry is seen as an opportunity for employers

- Development of an Associate Degree programme

- Sustainable construction industry

- Provision of tailored training programs

- Improvement of HR strategies to guarantee long-term employment prospects

- Use of tailored governmental subsidies

- Stronger public-private partnerships

- Healthcare sector

- Embracement of new technologies

- Creating a new mid-professional role

- Adequate rewards

- Transforming the hospital work environment

- Transform work processes, physical design, and hospital culture

General opportunities for sectoral policy interventions are based on a dual approach

- Within single firms: More attention to workforce planning and human resource development, together with improving the working conditions to not only retain existing staff but also attract new talent, even reaching segments that are closely related to the required field of work.

- Within the larger industry-wide or national context: More coordinated funding used strategically to support the establishment of new institutions, new programmes or multi-stakeholder initiatives. 
Sub-question 6: How do the opportunities and limitations/ possibilities and impossibilities of the instruments relate to each other, especially for the possible role of labour migration policy?

Answer:

- Although available data sources at European level are scarce, there seems to be hardly any oversupply in the EEA+ countries for the shortage occupations in the Netherlands, including those related to the three focus sectors. Therefore it is probably very difficult to recruit from the priority supply. We can conclude that it may be necessary to attract workers from third countries to fill the vacancies for these occupations.

- Although migration cannot be the only solution to filling skills shortages, migration can be one of the most efficient ways to address skills shortages.

- Medium-skilled migration from third countries is only possible through various rather restrictive channels.

- Migration is very much dependent on employers, who often prefer alternative solutions to recruiting migrants. This may be due to prejudices, stereotypes and lack of transparency on diplomas and competences of migrants, but also due to the lack of both general (social and language) skills as well as specific vocational skills. Furthermore, the procedures for the recognition of foreign qualifications are expensive and lengthy, which is in particular an obstacle for the healthcare sector.

- Alternative strategies to cope with skills shortages and to overcome staffing bottlenecks require both comprehensive policy adjustments at the national level and targeted HR policies within firms. Although they can be successful, it should be noted that all national strategies and HR policies require a lot of effort and huge investments.

- Employers may see labour migration as one of the tools to recruit people from abroad, and due to administrative barriers they often prefer to recruit workers from the Netherlands.

- Apart from the fact that firms could pay more attention to workforce planning and HR development in order to attract new talent, a more flexible migration policy, focused on the medium-skilled, could support firms in addressing labour market shortages. 


\section{Samenvatting}

Het aantrekken en behouden van migranten kan veel voordelen hebben voor het gastland en zijn economie, bijvoorbeeld om tekorten op de arbeidsmarkt op te vangen. Het reguleren van immigratie kan verschillende negatieve gevolgen van een krimpende en vergrijzende bevolking voorkomen. Onderzoek en beleid richten zich echter vaak op de hoogopgeleiden of zogenaamde kennismigranten als bron van menselijk kapitaal, hetgeen de innovatie en het concurrentievermogen van een land kan vergroten. Een groep arbeidsmigranten die aanzienlijk minder aandacht krijgt in onderzoek en beleid, zijn de middelbaar geschoolde arbeidsmigranten. Hoewel deze groep een aanzienlijk deel van de migrantenpopulatie uitmaakt, wordt zij zelden door specifiek migratiebeleid ondersteund.

Daarom willen wij in dit verslag een antwoord geven op de volgende centrale onderzoeksvraag, zoals die door het WODC is geformuleerd.

\section{Centrale onderzoeksvraag:}

Wat is er in beschikbare literatuur bekend over de kansen en beperkingen om in tekorten op de arbeidsmarkt te voorzien door middel van arbeidsmigratie, met name op het middensegment van de arbeidsmarkt?

De methodologie die wij hebben gebruikt voor het verzamelen van de relevante literatuur is gebaseerd op, ten eerste, een systematische zoektocht naar literatuur op basis van een vooraf vastgestelde reeks zoektermen. Daarbij hebben we ook gebruik gemaakt van de suggesties van het WODC en de Adviesraad voor dit project. Vervolgens hebben we een secundaire zoekactie uitgevoerd door middel van de sneeuwbaltechniek om aanvullende literatuur te identificeren op basis van de resultaten van de primaire zoekactie. Om de context over migratie naar Nederland en intra-EU migratie beter te begrijpen, werd aanvullende informatie gezocht, bijvoorbeeld statistieken en beleidsdocumenten van websites van relevante Nederlandse en Duitse overheidsinstellingen. Ten slotte hebben we ons netwerk van deskundigen geraadpleegd.

Dit rapport verkent eerst de arbeidstekorten op het middensegment van de Nederlandse arbeidsmarkt, met speciale aandacht voor de focussectoren metaal, energietransitie en gezondheidszorg, en bespreekt vervolgens de vaardigheidsvereisten en achtergrondkenmerken van werknemers per focussector. Het migratiedeel van het rapport vervolgt met een bespreking van het prioriteitsgenietend aanbod in de EER+ landen en in hoeverre dit aansluit bij het Nederlandse arbeidsvraag. Vervolgens gaat het rapport in op migratie als oplossing om tekorten in het middensegment van de Nederlandse arbeidsmarkt aan te pakken. Daarbij wordt gekeken naar relevante Europese en Nederlandse wetgeving op het gebied van migratie en de erkenning van kwalificaties. Verder wordt ingegaan op wat kan worden geleerd van Duitsland en enkele andere landen. Naast migratie wordt ook onderzocht in hoeverre andere oplossingsrichtingen kunnen voorzien in het oplossen van de geconstateerde tekorten op het middensegment van de Nederlandse arbeidsmarkt, in het bijzonder voor de drie focussectoren. Tot slot wordt ingegaan op de vraag hoe deze oplossingen zich verhouden tot de mogelijke rol van het arbeidsmigratiebeleid bij het 
aanpakken van knelpunten op de arbeidsmarkt, en worden enkele richtingen voor verder onderzoek besproken.

Meer specifiek gaat het rapport in op de volgende deelvragen, die door het WODC zijn afgeleid van de bovenstaande centrale onderzoeksvraag.

\section{Deelvragen:}

1. In welke sectoren van het middensegment van de Nederlandse arbeidsmarkt bestaan er tekorten aan werknemers? Hoe wordt hierbij het middensegment gedefinieerd? Welke sectoren worden in het onderzoek opgenomen, en waarom?

2. Wat zijn (per sector) de gewenste eigenschappen/ kenmerken van de gezochte werknemers, zoals: demografisch, vakopleidingen, expertises, vaardigheden en/of anderszins?

3. Bestaat er voor deze werknemers voldoende prioriteitgenietend aanbod in de EER en/of aanbod buiten de EER? Zo ja, welk aanbod en waar; waarom vinden de Nederlandse vraag en het buitenlandse aanbod elkaar niet?

4. Welke instrumenten kunnen een rol vervullen om de Nederlandse vraag en het buitenlandse aanbod bij elkaar te brengen? Waar liggen hierbij kansen en beperkingen/ mogelijkheden en onmogelijkheden voor het arbeidsmigratiebeleid?

5. Worden er andere mogelijke oplossingen genoemd voor de gesignaleerde tekorten in het middensegment van de Nederlandse arbeidsmarkt? Zo ja, welke?

6. Hoe verhouden de kansen en beperkingen/mogelijkheden en onmogelijkheden van de instrumenten zich tot elkaar, met name voor de mogelijke rol van het arbeidsmigratiebeleid?

Waar dat relevant is in dit verslag, zullen wij ook ingaan op het verwachte effect van de COVID19 pandemie op de geldigheid van de bevindingen. De samenvattingen van de antwoorden op de deelvragen volgen hieronder. 
Deelvraag 1: In welke sectoren van het middensegment van de Nederlandse arbeidsmarkt bestaan er tekorten aan werknemers? Hoe wordt hierbij het middensegment gedefinieerd? Welke sectoren worden in het onderzoek opgenomen, en waarom?

Antwoord:

- Op basis van een analyse van de grootste personele knelpunten voor werkgevers tot 2024 kan worden geconcludeerd welke bedrijfstakken het meest gebaat zouden zijn bij een ondersteunend migratiebeleid gericht op het middensegment van de arbeidsmarkt. Dit middensegment omvat alle personen die hun diploma hebben behaald op het hoogste niveau van het middelbaar beroepsonderwijs, dat wil zeggen op mbo 4-niveau.

- De volgende drie sectoren hebben op dit opleidingsniveau te maken met de grootste tekorten op de arbeidsmarkt: metaalindustrie, energietransitie (inclusief bouw en energie) en (gezondheids)zorg. Deze sectoren worden in dit rapport de focussectoren genoemd.

- $\quad$ Er is een behoorlijke overlap tussen de sectoren metaal en energietransitie (energie en bouw) met betrekking tot de meest prominente tekorten voor beroepen en opleidingstypen in het middensegment van de drie focussectoren. Binnen deze sectoren zullen de brede kernberoepen Onderhouds- en installatiemonteurs, Elektriciens en elektronica monteurs, en Technici in de bouw en natuur waarschijnlijk tot 2024 met grote knelpunten in de personeelsvoorziening te maken krijgen. Hetzelfde geldt voor de mbo 4-niveau opleidingstypen in deze sectoren: Werktuigbouwkunde en metaalbewerking, Elektro- en installatietechniek, Bouw en infrastructuur.

- Bovendien kunnen binnen de brede tekortberoepen van de sectoren metaal en energietransitie specifieke beroepen worden onderscheiden waarvoor werkgevers nu met grote personele knelpunten worden geconfronteerd. Op korte termijn zal deze situatie voor deze beroepen waarschijnlijk voortduren.

- In tegenstelling tot de metaalsector en de energietransitie sector is in de zorgsector het beroep van verpleegkundige het enige kernberoep in het middensegment van de arbeidsmarkt met grote knelpunten in de personeelsbezetting. Dit beroep is verwant aan de mbo 4-opleiding verpleegkundige en medisch ondersteuner. De werkzame verpleegkundigen zijn min of meer gelijk verdeeld over de sector zorg en de sector welzijn. Enige specialisatie voor verpleegkundigen is mogelijk op mbo 4niveau, maar voor echte specialisatie is een vervolgopleiding op bachelorniveau vereist. 
Deelvraag 2: Wat zijn (per sector) de gewenste eigenschappen/kenmerken van de gezochte werknemers, zoals: demografisch, vakopleidingen, expertises, vaardigheden en/of anderszins?

Antwoord:

- Werken in specifieke technische of zorgberoepen vereist weliswaar specifieke vaardigheden, maar uit ons literatuuronderzoek blijkt ook dat meer algemene sociale of intermenselijke vaardigheden en cultuur- of taalvaardigheden vaak minstens even belangrijk zijn. Arbeidsmigranten zijn duidelijk ondervertegenwoordigd in de zorgsector, evenals in de bouwsector.

- In de sector energietransitie zijn er veel specifieke beroepen die veel specialisatie vereisen, wat kan verklaren dat de vereiste vaardigheden (rekenvaardigheid en probleemoplossend vermogen) in de energiesector bovengemiddeld zijn, in tegenstelling tot de vereiste vaardigheden in de bouwsector. Werknemers in de metaalsector nemen doorgaans minder dan gemiddeld deel aan (langdurige) opleidingsactiviteiten.

- In de zorgsector werken veel vrouwen in deeltijdbanen, in tegenstelling tot de sectoren metaal en energietransitie. Jonge werknemers (tot 30 jaar) zijn ondervertegenwoordigd in de metaal- en energiesectoren van de industrie.

- Merk op dat de bovenstaande beschrijving van de achtergrondkenmerken van werknemers en de vaardigheidseisen in de focussectoren meestal niet exact bekend zijn voor werknemers op mbo 4-niveau, maar grotendeels gelden voor de gemiddelde werknemer per focussector.

- Bovendien omvat de metaalsector en met name de sector energietransitie een groot aantal subsectoren. Binnen de metaalsector kunnen we, naast andere subsectoren, de staalsector en de gereedschapsmachinesector onderscheiden. Binnen de energietransitie sector is de verscheidenheid aan subsectoren waarschijnlijk nog groter, met bijvoorbeeld de energiesectoren wind-, zonne-, waterkracht, bio-energie en de bouwsectoren technische installatie en duurzaam bouwen (onder andere). Let ook op dat niet alle economische activiteiten binnen deze deelsectoren noodzakelijkerwijs gerelateerd zijn aan de energietransitie.

Deelvraag 3: Bestaat er voor deze werknemers voldoende prioriteitgenietend aanbod in de EER+ landen en/of aanbod buiten de EER+ landen? Zo ja, welk aanbod en waar; waarom vinden de Nederlandse vraag en het buitenlandse aanbod elkaar niet?

Antwoord:

\section{Prioriteitgenietend aanbod}

- Tekorten aan vaardigheden die persoonlijk contact vereisen (bv. in de gezondheidszorg) en tekorten aan technische vaardigheden (STEM: scientific, technological, engineering or mathematical) zijn wijdverspreid en groot in de EER+ landen. Beroepen in de gezondheidszorg nemen een meer prominente plaats in dan in voorgaande jaren; verpleegkundigen staan zelfs op de eerste plaats van beroepen met een tekort.

- Hoewel er niet veel goede databronnen zijn, lijkt er in de EER+ landen nauwelijks overaanbod te zijn voor de tekortberoepen in Nederland, met inbegrip van de 
beroepen die verband houden met de drie focussectoren. Het is waarschijnlijk zeer moeilijk om te werven uit het beperkt beschikbare prioriteitsgenietend aanbod. We kunnen concluderen dat het nodig kan zijn om werknemers uit derde landen aan te trekken om de vacatures voor deze beroepen te vervullen.

\section{Relevantie van het aanbod uit van derdelanders}

- Vanwege de vergrijzing in de EER+ landen moet het aanbod van potentiële werknemers buiten deze gebieden worden gezocht.

- $E r$ is een potentieel aanbod in Afrika, maar dit is een relatief "korte termijn"oplossing.

- Het scheppen van meer mogelijkheden voor het vrije verkeer van derdelanders binnen het EER+ gebied zou een positief effect kunnen hebben op hun vraag naar en aanbod van arbeid.

- Versterking van de arbeidsmarktpositie van migrantenvrouwen kan ook het aanbod vergroten.

Beperkingen bij het matchen van de Nederlandse vraag en het buitenlandse aanbod

- Binnen de EER+ landen is er nauwelijks prioriteitsgenietend aanbod dat aansluit bij de vraag in Nederlandse tekortberoepen (zie hierboven).

- Het Europese en Nederlandse migratiebeleid is gericht op hoogopgeleiden, waardoor migratie van middelbaar opgeleiden moeilijker te realiseren is, ook al is er wel aanbod van buiten de EER+ landen en ook al zijn mensen bereid te migreren.

- De moeizame erkenning van buitenlandse diploma's en kwalificaties kan ertoe bijdragen dat veel migranten in Nederland niet of beperkt op banen terecht komen die passen bij hun vaardigheden.

Deelvraag 4: Welke instrumenten kunnen een rol vervullen om de Nederlandse vraag en het buitenlandse aanbod bij elkaar te brengen? Waar liggen hierbij kansen en beperkingen/ mogelijkheden en onmogelijkheden voor het arbeidsmigratiebeleid?

Antwoord:

\section{Beschikbare instrumenten}

- Er is geen wettelijk instrument dat specifiek gericht is op middelbaar opgeleiden (in het bijzonder op mbo 4-niveau).

- Migratie van middelbaar opgeleiden is mogelijk via verschillende, tamelijk restrictieve kanalen.

- Nederland heeft een gefragmenteerd migratiebeleid.

\section{Kansen}

- Migratie kan één van de meest efficiënte manieren zijn om tekorten aan vaardigheden aan te pakken.

- Migratie kan de werkloosheid in landen van herkomst en landen van eerder verblijf verlagen, bijvoorbeeld in het geval van intra-EER+ migratie van derdelanders.

- Migratie kan de Nederlandse beroepsbevolking verjongen.

- Detachering opent nieuwe mogelijkheden voor legale migratie.

- Gedetacheerde werknemers verblijven en werken officieel in een EER+ land, maar worden naar een tweede EER+ land gestuurd om daar tijdelijk een dienst te verlenen. Dit kan ook het uitlenen via een uitzendbureau omvatten.

- $\mathrm{Bij}$ de detachering van werknemers uit derde landen binnen de EER+ worden geen migratie-eisen gesteld door het land waarnaar de werknemer wordt uitgezonden.

- Circulaire migratie is een vorm van tijdelijke migratie waarbij een persoon herhaaldelijk heen en weer reist tussen twee of meer landen, gewoonlijk met het oog 
op werk. Regelingen voor circulaire migratie kunnen worden beschouwd als een flexibele manier om tekorten aan vaardigheden op te vangen en illegale migratie tegen te gaan.

- Circulaire migratie wordt geassocieerd met voordelen voor de migranten zelf en voor hun gast- en thuislanden, hoewel deze voordelen voor discussie vatbaar zijn.

\section{Beperkingen}

- Migratie kan niet de enige oplossing zijn om tekorten aan vaardigheden aan te vullen.

- Beperkt beschikbare instrumenten en langdurige procedures maken het moeilijk om tekorten op te vangen.

- Migratie is sterk afhankelijk van werkgevers, die vaak de voorkeur geven aan alternatieve oplossingen in plaats van migranten te werven, bijvoorbeeld vanwege vooroordelen en stereotypering.

- De procedures voor de erkenning van buitenlandse kwalificaties zijn duur en tijdrovend.

- Werkgevers kunnen detachering gebruiken (of zelfs misbruiken) om arbeidskosten te besparen.

- Meer specifieke informatie over de trends en dynamiek van detachering naar Nederland is schaars en we hebben geen literatuur kunnen vinden die ingaat op de detachering van TCN's die werkzaam zijn in de drie focussectoren.

\section{Mogelijkheden}

- Het vrije verkeer van derdelanders zou kunnen worden verbeterd door de richtlijn betreffende een gecombineerde vergunning uit te breiden.

- Er zijn mogelijkheden om een migratiebeleid in te voeren dat specifiek gericht is op het middelbaar geschoolde niveau (waaronder mbo 4-niveau), zoals de wet op de geschoolde immigratie in Duitsland (het "Fachkräfteeinwanderungsgesetz").

- De relatief nieuwe wet inzake immigratie van geschoolde werknemers in Duitsland ("Fachkräfteeinwanderungsgesetz", vanaf maart 2020 van kracht) biedt niet-EER+ migranten met intermediaire kwalificaties toegang tot bepaalde beroepen, stelt hen in staat werk te vinden in Duitsland, vergemakkelijkt de ontwikkeling van vaardigheden en verkort de doorlooptijden.

- Een permanent comité zou de vraag naar en het aanbod van arbeid kunnen onderzoeken, alsook de mogelijkheden voor arbeidsmigranten om aan de onvervulde arbeidsvraag te voldoen.

- Er zou sectoraal beleid kunnen worden ontwikkeld om tekorten op de arbeidsmarkt aan te pakken.

- Er zouden mobiliteitspartnerschappen (inclusief een programma's voor beroepsopleidingen) kunnen worden opgezet om de transnationale samenwerking voor de werving van middelbaar opgeleide werknemers uit te breiden.

- Een liberaler migratiebeleid, gericht op alle migranten ongeacht hun opleidings- of vaardigheidsniveau en beroep, zou kunnen worden overgenomen van Zweden; dit zou ook kunnen voorkomen dat er een nog gefragmenteerder arbeidsmigratiebeleid ontstaat.

- Werkgevers en het grote publiek bewuster maken van de voordelen van immigratie zou de werving van middelbaar geschoolde werknemers verder kunnen helpen bevorderen.

- Het fenomeen detachering betreft voor een belangrijk deel Oost-Europese werknemers; daarnaast is een groot deel van de gedetacheerde werknemers afkomstig uit West-Europese lidstaten die worden gedetacheerd naar andere WestEuropese lidstaten. Derdelanders met een geldige werk- en verblijfsvergunning in één EER+ land kunnen ook binnen andere EER+ landen worden gedetacheerd. 
- Binnen de EER+ worden steeds meer onderdanen van derde landen gedetacheerd en het gaat daarbij vooral om laag- en middelbaar geschoolde werknemers.

\section{Onmogelijkheden}

- Het is niet voldoende om een migratiebeleid uit te stippelen om middelbaar opgeleide werknemers aan te trekken, het is ook belangrijk om hen in de Nederlandse samenleving te integreren.

- Hoewel er aanwijzingen zijn dat de wet voor de immigratie van geschoolde werknemers ("Fachkräfteeinwanderungsgesetz") succesvol is geweest in het bevorderen van een grotere instroom van geschoolde migranten naar Duitsland, kan de erkenningsvereiste een groot obstakel zijn in Duitsland.

- Het Zweedse systeem kan een goed voorbeeld zijn voor Nederland. Het is effectief gebleken, hoewel er nog enkele tekortkomingen zijn, zoals het misbruik van werkzame migranten.

Er bestaan verschillende procedures voor de erkenning van buitenlandse kwalificaties als instrument om de Nederlandse vraag en het buitenlandse aanbod in de drie focus sectoren bij elkaar te brengen

- De procedure voor erkenning van beroepskwalificaties geldt voor mensen met een niet-automatisch erkende kwalificatie, behaald in een niet-EER+ land.

- Ten eerste kan het verkrijgen van erkenning van kwalificaties in beroepen in de gezondheidszorg een behoorlijk langdurig proces zijn, vooral voor houders van diploma's van buiten de EER+ landen. De erkenningsprocedures blijken ingewikkeld te zijn en worden door derdelanders vaak slecht begrepen, waardoor het een hele uitdaging is om de opties, de trajecten en de alternatieven te identificeren.

- Ten tweede is er een hoog uitvalpercentage in het proces.

- Voor de sectoren metaal en energietransitie zijn er geen gereglementeerde beroepen op mbo niveau-4 waarvoor diploma-erkenning verplicht is. Relevant voor migranten die in niet gereguleerde beroepen aan de slag willen, is de beoordeling van buitenlandse diploma's. Deze kan een goede indicatie geven van de waarde van een buitenlands diploma in Nederland en kan zowel gebruikt worden voor het vinden van passend werk als voor het vinden van een geschikte vervolgopleiding.

- Een laatste vorm van erkenning is de zogenaamde Erkenning van Verworven Competenties (EVC). De waarde van de EVC is sterk afhankelijk van de mate waarin werkgevers en onderwijsinstellingen de EVC-certificaten accepteren. Dit beleidsinstrument valt onder de strategie van een leven lang leren. EVC kan voor twee routes worden ingezet:

- Bij de arbeidsmarktroute worden eerdere leerresultaten van individuen gevalideerd aan de hand van de standaarden van de sector of organisatie.

- $\mathrm{Bij}$ de onderwijsroute van EVC krijgen aanvragers hun formeel/informeel/niet-formeel verworven competenties gevalideerd als een stap naar het behalen van een formele kwalificatie.

Deelvraag 5: Worden er in de literatuur andere mogelijke oplossingen genoemd voor de gesignaleerde tekorten in het middensegment van de Nederlandse arbeidsmarkt? Zo ja, welke?

Antwoord:

Algemene bevindingen inzake oplossingen voor personele knelpunten 
- Strategieën om tekorten aan vaardigheden aan te pakken en knelpunten in het personeelsbestand te verhelpen, vergen zowel brede beleidsaanpassingen op nationaal niveau als een gericht personeelsbeleid binnen de bedrijven.

- Op nationaal niveau zijn diverse succesvolle benaderingen gevolgd om vraag en aanbod op de arbeidsmarkt beter op elkaar af te stemmen en mensen aan te moedigen te studeren en te werken in specifieke gebieden met duidelijke tekorten, zoals STEM, ICT en R\&D.

- Er zijn voldoende aanwijzingen dat een op maat gesneden aanpak van HR management en ontwikkeling heeft bijgedragen tot het verlichten van de negatieve gevolgen van tekorten aan vaardigheden.

- Het gebruik van verschillende wervingskanalen (zoals uitzendbureaus en andere intermediaire organisaties, grensoverschrijdende detacheringen) kan ook nuttig zijn bij het vervullen van vacatures.

- Aan de vraagzijde: Compensatie, werving en taakstructurering zijn componenten van een strategie voor het tegengaan van een tekorten aan vaardigheden.

- Aan de aanbodzijde: Strategieën gericht op het aanbieden van nieuwe opleidingen of het ontwerpen van nieuwe opleidingsprogramma's, en strategieën om institutionele belemmeringen te verminderen door de invoering van betere regelingen voor onderwijs en werving.

- Het is belangrijk om werknemers een T-pakket van noodzakelijke vaardigheden te geven om gemakkelijk van het ene specialisme naar het andere over te stappen.

- Bovengenoemde strategieën zijn gewoonlijk niet specifiek voor het middensegment van de arbeidsmarkt, afgezien van de maatregelen die kunnen worden genomen om het stelsel van beroepsopleidingen te verbeteren en de werving van stagiaires te bevorderen.

\section{Bevindingen voor de drie focus sectoren om de knelpunten op personeelsgebied aan te pakken}

- Metaal sector

- Interne opleidingen voor de ontwikkeling van $\mathrm{T}$-vaardigheden

- HR strategieën bevorderen

- On(der)benut potentieel op de arbeidsmarkt aanboren

- Intensivering van de samenwerking en uitwisseling van personeel met onderwijsinstellingen

- Versterking van de capaciteit van publiek-private partnerschappen

- Gerichte opleidingssubsidies voor kleine ondernemingen

- De trend van de automatisering volgen: aanpassen aan technologische veranderingen

- Energietransitie sector (voorbeelden van drie subsectors)

$\circ$ Windenergie industrie

- Bevordering van korte en flexibele beroepsopleidingscursussen

- Bevordering van samenwerking tussen het bedrijfsleven en de academische wereld

- Bevordering van relevante kennis uit de industrie in academische opleidingen

- Harmonisatie van beroepsopleidingen in de Europese context

- Een goed geplande nationale onderwijs- en opleidingsstrategie

- Het opzetten van investeringsprogramma's samen met andere werkgevers, zoals duale onderwijssystemen

- Transnationale netwerken kunnen de acceptatie mogelijk maken van kwalificaties die zijn afgegeven door instellingen in het buitenland om internationale mobiliteit te vergemakkelijken

- Technische installatiebranche (TI) 
- Gezondheidszorg

- Werving van personeel van buiten de TI-industrie wordt gezien als een kans voor werkgevers

- Duurzame bouwsector

- Ontwikkeling van een programma voor Associate Degree

- Het aanbieden van op maat gemaakte opleidingsprogramma's

- Verbetering van HR-strategieën om werkgelegenheidsperspectieven op lange termijn te garanderen

- Gebruik van op maat gesneden overheidssubsidies

- Sterkere publiek-private partnerschappen

- Omarming van nieuwe technologieën

- Creëren van een nieuwe mid-professionele rol

- Passende beloning

- De werkomgeving van het ziekenhuis transformeren

- Werkprocessen, fysiek ontwerp en ziekenhuiscultuur transformeren

Generieke mogelijkheden voor sectorale beleidsmaatregelen zijn gebaseerd op een tweeledige aanpak

- Binnen afzonderlijke bedrijven: Meer aandacht voor de planning van het personeelsbestand en de ontwikkeling van de menselijke hulpbronnen, samen met de verbetering van de arbeidsomstandigheden om niet alleen het bestaande personeel te behouden maar ook nieuw talent aan te trekken, waarbij segmenten op de arbeidsmarkt worden aangeboord die nauw verband houden met het vereiste werkterrein.

- Binnen de bredere sectorale of nationale context: Meer gecoördineerde financiering die strategisch wordt gebruikt om de oprichting van nieuwe instellingen, nieuwe programma's of multi-stakeholder initiatieven te ondersteunen.

Deelvraag 6: Hoe verhouden de kansen en beperkingen/ mogelijkheden en onmogelijkheden van de instrumenten zich tot elkaar, met name voor de mogelijke rol van het arbeidsmigratiebeleid?

Antwoord:

- Hoewel er op Europese schaal weinig databronnen voorhanden zijn, lijkt er in de EER+ landen nauwelijks overaanbod te zijn voor de tekortberoepen in Nederland, ook niet voor de drie focus sectoren. Daarom is het waarschijnlijk erg moeilijk om te werven uit het prioriteitgenietend aanbod in de EER+. We kunnen concluderen dat het nodig kan zijn om werknemers uit derde landen aan te trekken om de vacatures voor de tekortberoepen te vervullen.

- Hoewel migratie niet de enige oplossing kan zijn om tekorten aan te vullen, kan migratie wel één van de meest efficiënte manieren zijn om vacatures in te vullen.

- Migratie van middelbaar opgeleiden uit derde landen is alleen mogelijk via verschillende restrictieve kanalen.

- Migratie is sterk afhankelijk van werkgevers, die vaak de voorkeur geven aan alternatieve oplossingen in plaats van migranten te werven. Dit kan te wijten zijn aan vooroordelen, stereotypen en een gebrek aan transparantie over diploma's en competenties van migranten, maar ook aan het gebrek aan zowel algemene (sociale en taal) vaardigheden als specifieke beroepsvaardigheden. Bovendien zijn de 
procedures voor de erkenning van buitenlandse kwalificaties duur en tijdrovend, wat met name voor de gezondheidszorgsector een belemmering vormt.

- Alternatieve strategieën om tekorten op te vangen en knelpunten te verhelpen, vereisen zowel brede beleidsaanpassingen op nationaal niveau als een gericht HRbeleid binnen de bedrijven. Hoewel zij succesvol kunnen zijn, moet worden opgemerkt dat nieuwe nationale strategieën en aanpassingen aan het HR-beleid veel inspanning en enorme investeringen vergen.

- Werkgevers kunnen arbeidsmigratie zien als één van de instrumenten om mensen uit het buitenland te werven. Vanwege de administratieve belemmeringen geven zij vaak de voorkeur aan werknemers uit Nederland.

- Afgezien van het feit dat bedrijven meer aandacht kunnen besteden aan personeelsplanning en HR-ontwikkeling om nieuw talent aan te trekken, kan een flexibeler migratiebeleid, gericht op middelbaar opgeleiden, bedrijven ondersteunen bij het aanpakken van tekorten op de arbeidsmarkt. 


\section{Introduction}

Attracting and retaining migrants can have many benefits for the host country and its economy, for example to mitigate skills shortages. A recent report by NIDI \& CBS (2021) shows that regulating immigration can be a useful tool in preventing several negative consequences of a shrinking and ageing population, such as an increase in the demand for healthcare and a simultaneous decrease in the working population. To mitigate these consequences, policy instruments that are complementary to increasing immigration flows should aim to encourage labour participation (in percentages and hours per week) of women, older people and migrants already living in the Netherlands.

Research and policy often focus on the highly skilled or so-called knowledge migrants (kennismigranten) as a source of human capital, which can increase innovation and a country's competitiveness. At the same time, low-skilled migration is often necessary to fill positions in the labour market that are less popular among the native population (Castles et al, 2014). In the case of the Netherlands, low-skilled migrants often come from other European countries like Poland and Romania, making use of their right to free movement (CBS, 2019a). A group of labour migrants that receives significantly less attention from research and policy, are the medium-skilled, who are rarely supported by specific migration policies, also in the Dutch case. Considering that this group of migrants makes up a significant, and depending on the context even the largest share of the migrant population (Fries-Tersch et al, 2021), this is rather surprising.

The above refers to the central research question of our commissioner WODC.

Central research question of the WODC:

What is known in available literature about the opportunities and limitations of filling labour shortages through labour migration, especially in the middle segment of the labour market?

The WODC has derived six sub-questions from the above central research question. These will be answered in the Sections 3 to 7 of this report. The sub-questions have been formulated as follows. 
Sub-questions of the WODC:

1. In which sectors of the middle segment of the Dutch labour market are there shortages of employees? Which sectors are included in the study, and why?

2. What are the desired characteristics of the sought-after workers (per sector), such as: demographics, professional education, expertise, skills and/or other?

3. Is there a sufficient priority supply for these workers in the EEA and/or outside the EEA? If so, which supply and where; why do the Dutch demand and the foreign supply not match?

4. Which instruments can play a role in bringing the Dutch demand and the foreign supply together? Where do the opportunities and limitations lie in this respect / possibilities and impossibilities for labour migration policy?

5. Have other possible solutions been mentioned for the identified shortages in the middle segment of the Dutch labour market? If so, which?

6. How do the opportunities and limitations/ possibilities and impossibilities of the instruments relate to each other, especially for the possible role of labour migration policy?

Where relevant in this report, we will also discuss the expected impact of the COVID-19 pandemic on the validity of the findings.

This study focuses on three sectors of industry, namely the metal sector of industry, the energy transition sector, and the healthcare sector. For these three sectors of industry we conduct a further in-depth analysis on staffing bottlenecks and on the opportunities to recruit migrants at the upper secondary vocational level of education. The selection of sectors is based on the expected staffing bottlenecks up to 2024 published by the Research Centre for Education and the Labour Market (Bakens et al., 2019) ${ }^{1}$, on the most figures for the largest staffing bottlenecks for occupations and hard-to-fill vacancies that employers expect according to the UWV (2020, 2021a), and on a recent report of the ACVZ (2021a, b) exploring the opportunities for asylum seekers to be employed in the healthcare sector. ${ }^{2}$ We will further justify the selection of these sectors of industry in Section 3.

For each sector, we distinguish between three migrant groups that could contribute to mitigating shortages of the Dutch labour market: (1) third-country nationals (TCNs), (2) TCNs residing within EEA+ countries, and (3) nationals from EEA+ countries/ intra-EU migrants. The latter two groups form the so-called 'priority supply'. Before recruiting TCNs from outside EEA+ countries, employers should show that they cannot find suitable employees from these groups. The distinction between the three groups is made because different legal frameworks apply with regard to their migration to the Netherlands. Citizens from EEA+ countries enjoy the right to free movement between the Member States without any further migration requirements, such as visas, work or residence permits. For TCNs residing in EEA+ countries and beyond,

1 See https://roa.nl/research/research-projects/project-onderwijs-arbeidsmarkt-poa for the ROA research on labour market forecasting.

2 Apart from the figures, our commissioner WODC had a strong preference for including the energy transition sector, as this is a promising new sector for further economic growth. 
the situation is different (see Section 5 for a more detailed overview). Throughout the report, we aim at using the same terminology when referring to the three migrant groups: TCNs, EEA+ nationals, and TCNs in EEA+ countries. Migration within the EEA+ countries is referred to as intra-EEA+ migration of EEA+ nationals or TCNs. Since the reviewed literature and other data sources may use other terms and definitions, it is possible that we sometimes use other terms as well.

\section{A note on terminology: migration versus mobility}

In EU legislation, EEA+ citizens and their families can move to, work and live in another EEA+ country. The EU refers to movements within the Union as mobility, and movements from non-EEA+ to EEA+ countries as migration, and vice versa, as mobility. Some scholars argue that the distinction between migration and mobility is made to identify TCNs as the other and to maintain the external borders of the Union (Rogoz \& Perchinig, 2019, p. 5; Amelina, 2017).

International organisations do not share the EU's approach of distinguishing between mobility and migration. EU Member States and EEA+ countries are seen as sovereign states in international law, and neither the Council of Europe nor the United Nations use the term mobility to refer to intra-EEA+ movements. Approaches by migration researchers differ. Rogoz and Perchinig (2019) argue that EU Member States and EEA+ countries are still separated by international borders even if border controls have been abolished and EEA+ citizens enjoy the freedom of movement. Therefore intra-EEA+ movements are seen as international migration (Rogoz \& Perchinig, 2019). Furthermore, intra-EEA+ movements involve many barriers that are similar to movements across EEA+ borders (see Section 4 of this report). For these reasons, this report uses the term intra-EEA+ migration instead of intra-EEA+ mobility.

Table 1: Key definitions in the study

\begin{tabular}{|l|l|}
\hline EEA+ countries & $\begin{array}{l}\text { Countries of the European Economic Area (EEA), which includes the 27 EU } \\
\text { member states, Norway, Iceland and Liechtenstein, plus Switzerland. }\end{array}$ \\
\hline $\begin{array}{l}\text { Middle segment }= \\
\text { medium-skilled } \\
\text { workers }\end{array}$ & $\begin{array}{l}\text { Workers with a three or four-year intermediate vocational education (mbo 4- } \\
\text { level in the Netherlands). According to the International Standard } \\
\text { Classification of Education (ISCED) of the UNESCO, this level equals upper } \\
\text { secondary vocational education (level completion at ISCED category 3, } \\
\text { subcategory 354) } \text {, which gives direct access to tertiary education (contrary }^{3} \\
\text { to mbo level-1/2/3 and lower ISCED levels). Note that our definition is rather } \\
\text { narrow. In general, both lower and upper secondary vocational and general } \\
\text { level completion may refer to the middle segment of medium-skilled workers. }\end{array}$ \\
\hline Labour migration & $\begin{array}{l}\text { For the purpose of this report, labour migration is defined as the international } \\
\text { movement of persons for the purpose of employment (adapted from IOM, } \\
\text { 2019). Three groups of migrants are distinguished in this study: } \\
\text { (1) Third-country nationals (TCNs) from outside the EEA+ countries. } \\
\text { (2) TCNs residing within the EEA+ countries. } \\
\text { (3) Foreign nationals from the EEA+ countries. } \\
\text { This distinction is made because depending on the migrants' nationality and } \\
\text { official country of residence, their legal rights to live and work in the } \\
\text { Netherlands differ. }\end{array}$ \\
\hline
\end{tabular}

3 international-standard-classification-of-education-isced-2011-en.pdf (unesco.org) 


\begin{tabular}{|l|l|}
\hline Priority supply & $\begin{array}{l}\text { Workers from EEA+ countries and TCNs residing within EEA+ countries are } \\
\text { given priority when recruiting for the Dutch labour market. TCNs from outside } \\
\text { the EEA+ countries can only receive a work permit (TWV) if the employer } \\
\text { has proven to the Netherlands Employee Insurance Agency (UWV) that it is } \\
\text { not possible to fill the respective vacancy with a worker from the priority } \\
\text { supply. }\end{array}$ \\
\hline Skill shortage & $\begin{array}{l}\text { Labour market condition where there is (near) full employment, and a } \\
\text { general difficulty in finding workers to fill vacancies (Boswell et al., 2004) or } \\
\text { when employers are unable to recruit staff with the required skills in the } \\
\text { accessible labour market and at the ongoing rate of pay (Brunello and } \\
\text { Wruuck, 2019). }\end{array}$ \\
\hline
\end{tabular}

The report is structured as follows. Section 2 explains the methodology we used for collecting the relevant literature. Section 3 first explores the labour shortages in the middle segment of the Dutch labour market, with a special focus on the metal, energy transition and healthcare sectors, and next discusses the skills requirements and background characteristics of workers per focus sector. Section 4 discusses the priority supply in the EEA+ countries and to what extent this can match Dutch labour supply. Section 5 examines migration as a solution to address shortages in the middle segment of the Dutch labour market. In doing so, it reviews relevant European and Dutch legislation on migration as well as the recognition of qualifications. Furthermore, it discusses what can be learnt from Germany and some other countries. Section 6 explores to what extent other possible solutions are possible to meet the identified shortages in the middle segment of the Dutch labour market, in particular for the three focus sectors. Section 7 concludes with how these solutions relate to the possible role of labour migration policy to tackle bottlenecks on the labour market. The section will also discuss some directions for further research. At the beginning of each section, we mention the most relevant sub-question(s) for the section. At the end of each section, we repeat the subquestion(s) and give the answers in a text box. 


\section{Methodology}

To identify the relevant literature for this study, several strategies were used. These are listed below.

1. A systematic search for literature based on a predefined set of search terms covering the topics 'Strategies to mitigate labour shortages', 'Migration as a strategy to mitigate labour shortages' and 'Related policy' was conducted. All search terms were used in combination with the focus sectors and occupations of this report. Search engines used for the search include Google Scholar, the Maastricht University Library and relevant journals publishing in related fields. The search was conducted in English and Dutch and limited to the first 50 results per search term identified by the different search engines. It excluded work that was published before 2016. The complete overview of all search terms used can be found in Annex 1.

2. The literature referred to in the kick-off memo of the WODC and the tender as well as readings recommended by the Advisory board were reviewed and databases of key actors (e.g. ACVZ, Het Kenniscentrum over Arbeidsmigranten) were explored to find additional literature.

3. After that we conducted a secondary search, including the following steps:

- We used the snowballing technique to identify additional literature from the results of the primary search.

- Additional information was searched to better understand the context about migration to the Netherlands and intra-EU migration (e.g. statistics).

- For policy documents websites of relevant Dutch and German government institutions were searched.

Finally, we consulted our network for references to relevant studies to be included in our literature review (see Table 2).

Table 2: Contact persons for literature references

\begin{tabular}{|c|c|}
\hline $\begin{array}{l}\text { Labour market shortages and } \\
\text { staffing bottlenecks }\end{array}$ & $\begin{array}{l}\text { - Jessie Bakens, ROA/Maastricht University } \\
\text { - Bart van Krimpen, Randstad } \\
\text { - Michel van Smoorenburg, UWV }\end{array}$ \\
\hline Work permits & - Michel van Smoorenburg, UWV \\
\hline Education and VET policies & $\begin{array}{l}\text { - Rianne Huiberts, SBB } \\
\text { - Rutger van der Ven, Ministry of Education, Culture and } \\
\quad \text { Science (OCW) }\end{array}$ \\
\hline $\begin{array}{l}\text { Foreign Qualification } \\
\text { Recognition and VPL (EVC) }\end{array}$ & $\begin{array}{l}\text { - Rianne Huiberts, SBB } \\
\text { - Lavinia Kortese, ITEM/Maastricht University } \\
\text { - Hildegard Schneider, ITEM/Maastricht University }\end{array}$ \\
\hline Migration policies & $\begin{array}{l}\text { - Sonja Avontuur, ACVZ } \\
\text { - Herbert Brücker, IAB/Berlin Institute for Empirical } \\
\text { Integration- and Migration Research (BIM) } \\
\text { - Katrin Marchand, UNU-MERIT/Maastricht University }\end{array}$ \\
\hline
\end{tabular}


- Christine Otten, ACVZ

- Melissa Siegel, UNU-MERIT/Maastricht University

All identified literature was checked for relevance based on title, abstract and a quick search for key terms such as 'medium-skilled migration' and the focus sectors and occupations, and excluded if it did not provide information contributing to answering any of the research questions. The identified literature was added to a systematic database of resources. All publications we identified are listed in the references section at the end of this report.

The following sources were regarded as especially relevant in understanding the role of medium-skilled migration in mitigating shortages in the middle segment of the Dutch labour market:

- ACVZ. (2021). Van asielzoeker naar zorgverlener. Arbeidsdeelname van asielmigranten in de zorgsector. Kenmerk 53 - 2021, mei, Den Haag.

- Advisory Committee on Migration Affairs (ACVZ). (2020). Legal Channels for Migrant Workers. An exploratory study. 73.

- Avontuur, S \& Otten, C. (2021). Migratie en de zorgsector. Cijfers over de arbeidsmarkt in de zorgsector en de arbeidsdeelname van migranten, Kenmerk 54 2021, mei, Den Haag.

- De Lange, T., \& Groenendijk, K. (2021). The EU's legal migration acquis: Patching up the patchwork. European Policy Centre Issue paper.

- De Lange, T., Oomes, N., Gons, N., \& Spanikova, V. (2019). Labour Migration and Labour Market Integration of Migrants in the Netherlands: Barriers and Opportunities. 62.

- Doukas, H., Siskos, E., Psarras, J., Malamatenios, C., Tournaki, S., \& Tsoutsos, T. (2016). Qualification roadmap empowering the Greek building sector workforce in the field of energy. Renewable and Sustainable Energy Reviews, 65, 992-1004. https://doi.org/10.1016/j.rser.2016.07.022

- European Commission. (2020a). Analysis of shortage and surplus occupations 2020. Directorate-General for Employment, Social Affairs and Inclusion. Brussels. https://op.europa.eu/en/publication-detail/-/publication/22189434-395d-11eb-b27b01aa75ed71a1/language-en

- European Commission. (2020b). Intra-EU Labour Mobility at a glance: Main findings of the 2019 Annual Report on intra-EU Labour Mobility. https://ec.europa.eu/social/main.jsp?catld=738\&langld=en\&publd=8242\&furtherPu $\underline{\mathrm{bs}=\mathrm{yes}}$

- Fries-Tersch, E., Jones, E., \& Siöland, M. (2021). Annual Report on Intra-EU Labour Mobility 2020.

https://ec.europa.eu/social/main.jsp?catld=738\&langld=en\&publd=8369

- Oomes, N., Dietz, T., \& Duvell, F. (2019). Dutch labour market shortages and potential labour supply from Africa and the Middle East: Is there a Match? SEO Amsterdam Economics. 
- Bakens, J., Bijlsma, I., Dijksman, S., Fouarge, D., \& de Lombaerde, G. (2019). De arbeidsmarkt naar opleiding en beroep tot 2024. ROA. ROA Reports No. 007 https://doi.org/10.26481/umarep.2019007

https://roa.nl/research/research-projects/project-onderwijs-arbeidsmarkt-poa

- UWV. (2021). Verwachtingen werkgevers voor 2021, Indicatie uit werkgeversenquête UWV 1 april 2021.

https://www.werk.nl/imagesdxa/verwachtingen werkgevers voor 2021 tcm95427707.pdf

- Weterings, A., Bakens, J., Ivanova, O., \& Fouarge, D. (2019). Frictie op de arbeidsmarkt door de energietransitie: Een modelverkenning. PBL \& ROA, 49.

https://www.pbl.nl/sites/default/files/downloads/pbl-2019-frictie-op-de-arbeidsmarktdoor-de-energietransitie-3438.pdf 


\section{Shortages and skill requirements in the middle segment of the Dutch labour market}

Having defined the middle segment as the mbo 4-level group of workers, we can further analyse this labour market segment. In this section, we aim to answer the first and second set of sub-questions: (1) In which sectors of the middle segment of the Dutch labour market are there shortages of employees? Which sectors are included in the study, and why?; (2) What are the desired characteristics of the sought-after workers (per sector), such as: demographics, professional education, expertise, skills and/or other? The answers are given successively in Sections 3.1 and 3.2 below.

\subsection{Identification of focus sectors and most important skill shortages}

\section{Identification of three focus sectors}

The identification of the focus sectors for the middle segment of the labour market is based on a general assessment of the most important skill shortages for this segment. To this end we use the ROA Labour Market Information System (ArbeidsmarktInformatieSysteem, AIS). ${ }^{4}$ Table 3 shows that there were 1,507,000 medium-skilled workers at the mbo 4-level of education employed in 2018-19 (mean), accounting for $17 \%$ of the entire working population (of about 8.9 million people). The sector with the largest share of mediumskilled workers (mbo 4-level) is agriculture, forestry and fishing, followed by welfare, construction, metal industry and energy. In terms of absolute numbers, only care and welfare (together: healthcare) have more than 100,000 mbo 4-level persons working in these sectors.

Table 3: Employment of medium-skilled at the mbo 4-level

\begin{tabular}{|l|r|r|}
\hline & \multicolumn{2}{|c|}{$\begin{array}{c}\text { Medium-skilled workers } \\
\text { (mbo 4-level) }\end{array}$} \\
\hline Sector of industry & $\%$ & $\begin{array}{r}\text { Absolute } \\
\text { number }\end{array}$ \\
\hline Agriculture, forestry and fishing & 28 & 4,500 \\
\hline Welfare & 24 & 180,500 \\
\hline Construction & 22 & 91,500 \\
\hline Wholesale & 21 & 86,500 \\
\hline Metal industry & 19 & 58,000 \\
\hline Energy & 19 & 14,500 \\
\hline Other services, households and extraterritorial organisations & 19 & 36,500 \\
\hline
\end{tabular}

4 See for the AIS: https://roa.nl/research/research-projects/project-onderwijs-arbeidsmarkt-poa. 


\begin{tabular}{|l|r|r|}
\hline Chemical industry & 18 & 23,000 \\
\hline Retail trade & 18 & 16,000 \\
\hline Other manufacturing & 17 & 44,500 \\
\hline Transport and storage & 17 & 70,000 \\
\hline Public administration and government services & 17 & 88,000 \\
\hline Total in the Netherlands & 17 & $1,507,000$ \\
\hline Food and beverage industry & 16 & 22.500 \\
\hline Financial services and real estate & 16 & 52,000 \\
\hline Care & 16 & 101,500 \\
\hline Renting and other business services & 15 & 73,000 \\
\hline Culture, sport and recreation & 14 & 27,000 \\
\hline Hospitality & 13 & 53,500 \\
\hline Information and communication & 13 & 39,500 \\
\hline Specialist business services & 13 & 86,500 \\
\hline Education & 8 & 48,000 \\
\hline
\end{tabular}

Source: ROA/AIS/LFS average 2018-2019

We also reveal for each sector the types of education (i.e. field) at the upper secondary vocational education level (mbo 4-level) with the largest shares and numbers of workers as well as the largest expected future staffing bottlenecks for employers. ${ }^{5}$ These education types are listed in Table 4.

Table 4: Most important mbo 4-level types of education with largest expected staffing bottlenecks up to 2024 per sector of industry

\begin{tabular}{|l|l|}
\hline Sector of industry & Type of education* \\
\hline Agriculture, Forestry and Fishing & Mbo 4 - agriculture and animal care \\
\hline Metal industry & Mbo 4 - mechanical engineering and metalworking \\
\hline Construction & Mbo 4 - electrical and installation engineering \\
\hline
\end{tabular}

5 See https://roa.nl/research/research-projects/project-onderwijs-arbeidsmarkt-poa and the accompanying publication De arbeidsmarkt naar opleiding en beroep tot 2024 for labour market shortages and background characteristics for more than 100 types of education and occupation groups (Bakens et al., 2019). See for the relatively minor impact of the COVID-19 crisis on the occupations with the highest vacancy rates Bakens et al. (2020). 


\begin{tabular}{|l|l|}
\hline Construction & Mbo 4 - construction and infrastructure \\
\hline Care & Mbo 4 - nursing and medical support \\
\hline
\end{tabular}

Source: ROA/AIS

Note: Only large or very large expected future staffing bottlenecks for types of education with a share of at least $5 \%$ in sectoral employment are shown; mind that the Agriculture, Forestry and Fishing sector has only a small number of medium-skilled workers with mbo 4-level Agriculture and animal care (see Table 3)

From Table 3 and Table 4 it can be concluded which sectors of industry would benefit most from a supportive migration policy aimed at the middle segment (mbo 4) of the labour market. First, we suppose that the sectors of industry listed in Table 4 will face the largest staffing bottlenecks up to 2024. Out of these sectors, agriculture, forestry and fishery has the smallest number of workers at the mbo 4-level (4,500 workers). Furthermore, if we suppose that the energy transition will largely take place in the construction (91,500 workers) and energy sector (14,500 workers), and apart from the agriculture, forestry and fishery sector, the following three sectors ${ }^{6}$ would benefit most from this policy: metal industry $(58,000$ workers), energy transition (91,500 workers in the construction sector and 14,500 workers in the energy sector) and healthcare (in particular care: 101.500 workers). ${ }^{7}$ Note that on the one hand the educational types for which employers face labour market shortages represent just a share of the total workforce of these sectors, on the other hand also employers of other sectors face similar shortages for workers with the same educational background.

\section{Most important shortage occupations and education types in the focus sectors}

We now discuss the most important shortage occupations and education types in the middle segment of the three focus sectors. The metal sector of industry suffers very much from the shortage of (mechanical) engineers (i.e. (Machine)monteurs in Dutch). In this occupation, many workers have completed the mbo level 4 Mechanical engineering and metalworking education (mbo 4 Werktuigbouwkunde en metaalbewerking). These workers are also needed for the energy transition. Therefore, Maintenance and installation engineers are in high demand. For these occupations, labour and asylum migrants from both within and outside the EEA+ countries may be an interesting potential group of workers. ${ }^{8}$

In addition to the regular installation and maintenance work in the metal and the construction sectors of industry, the energy transition is creating a need for installers of solar panels and heat pumps, ${ }^{9}$ for which often an Electrical and installation engineering education at mbo 4-level (mbo 4 Elektro- en installatietechniek) is required. The economic activities regarding the energy transition mainly take place in the construction, installation engineering (including e.g. heat pumps and solar panels) and energy sectors of industry. In these sectors we consider the Electricians and electronics mechanics (i.e. Elektriciens en

6 Note that the commissioner WODC requested us to focus on three sectors of industry, with the energy transition sector as one of the three.

7 The information below on types of education and occupation per focus sector is also based on the ROA ArbeidsmarktInformatieSystem (AIS) available at https://roa.nl/research/research-projects/project-onderwijsarbeidsmarkt-poa

8 See for example Eindhovens Dagblad (2018). Stedin wil asielzoekers opleiden tot monteur. augustus.

9 See Kansrijke beroepen, kies techniek (werk. nl). 
elektronicamonteurs in Dutch) as the most important shortage occupation. In this occupation many workers have completed the mbo 4-level Electrical and installation engineering education (mbo 4 Elektro- en installatietechniek). In addition, also the occupation Technicians in construction and nature (Technici bouw en natuur) ${ }^{10}$ is strongly represented in the construction and energy sectors. To work in this occupation many workers have completed mbo 4-level Construction and infrastructure (mbo 4 Bouw en infra) as well as the above mentioned mbo 4-level Mechanical engineering and metalworking and mbo 4-level Electrical and installation engineering educations.

The healthcare sector has large staffing bottlenecks for Nurses (Verpleegkundigen mbo). This occupation has a strong 1-to-1 tie to the mbo 4-level Nursing and medical support education (mbo 4 Verpleegkunde en medische ondersteuning). The healthcare sector is particularly interesting since there is automatic recognition of diplomas for some occupations (in particular in healthcare), but only for diplomas of EEA+ countries. The recognition procedures for diplomas differ per sector or occupation and differ for diplomas from either EEA+ countries or third countries. For occupations in the middle labour market segment, including those in the healthcare sector, the so-called VPL-procedure (Validation of Prior Learning, EVC in Dutch: Erkenning van Verworven Competenties) applies, which refers to the recognition of competencies acquired previously without the requirement of a diploma attached to it. This is, among other issues, part of the ongoing research of the Dutch Advisory Committee on Migration Affairs (Adviescommissie voor Vreemdelingenzaken, ACVZ) to explore the possibilities and limitations of the deployment of asylum seekers and asylum holders (asielzoekers en statushouders in Dutch) in the healthcare sector.

In Table 5 we summarize the types of education and occupation with the largest labour market shortages per focus sector. The broad occupations (occupational groups) and the types of education have been retrieved from the ROA/AIS database.

Table 5: Broad occupations and types of education with largest expected staffing bottlenecks up to 2024 , middle segment of the labour market per focus sector

\begin{tabular}{|l|}
\hline Metal industry \\
- Middle segment occupation: (Mechanical) engineers \\
- Mbo 4-level education: Mechanical engineering and metalworking \\
Energy transition (energy and construction sectors) \\
- Middle segment occupations: Maintenance and installation engineers, Electricians and \\
electronics mechanics, Technicians in construction and nature \\
- Mbo 4-level education: Mechanical engineering and metalworking, Electrical and installation \\
engineering, Construction and infrastructure \\
Healthcare sector \\
- Middle segment occupations: Nurses
\end{tabular}

10 Note that for this occupation there are also many workers who have a bachelor in higher vocational technical education or an education in forest management. 
- Mbo 4-level education: Nursing and medical support

Source: ROA/AIS

\section{Most important specific occupations in the focus sectors}

Apart from the above information in the ROA/AIS database, we below show more detailed UWV information on occupations with the best current job opportunities for a job and the latest largest staffing bottlenecks for occupations that are expected in the short term by employers UWV $(2020,2021 a) .{ }^{11}$ The occupations listed below give a more detailed picture of the occupational background of the personnel that is most needed per focus sector. Both the broad and the specific occupations per focus sector will be used to reveal information on labour market shortages and migration from the studies in our literature review.

Table 6: Specific occupations with largest current or short-term expected labour market shortages per focus sector

Metal industry (derived from manufacturing industry)

- Technical craftsmen:

- Mechanics of installations/mechatronics (installation, faults, service)

- (CNC) machinists/operators

- Welders, metalworkers

- Mechanics of assembly

- Foremen, project leaders, shift leaders

- Work planners/calculators

- Engineers industry: ict, electro, materials, systems

Energy transition (derived from construction and installation sector)

- Mechanics (installation, malfunction, service, maintenance):

- Plumbers (gas, water)

- Electricians (including solar panels)

- Electricity network technicians

- Telecommunications systems mechanics, fibre optics mechanics

- Gas, water, plumbing and heating mechanics (incl. heat pumps)

- Electricians, electrical installation technicians (incl. solar panels)

- Installers of air treatment, ventilation and refrigeration technology

- Electrotechnical service technicians

- Planners of interior construction companies

- Engineering contractors for civil engineering

- Site surveyors and civil engineering staff

- Draftsmen, work preparers, calculators civil engineering

- Surveyors, project leaders land surveying

- Main construction and installation contractors

- Work planners, construction calculators

- Construction inspectors / advisers

Care sector

- Nurses general

- Nurses specialised

Source: UWV (2020, 2021a)

11 This is the most recent information available from UWV, taking into account the influence of COVID-19. 


\subsection{Required background characteristics and skills for workers in the focus sectors}

The skills required in the focus sectors can be of a very different nature. Employers usually seek a mix of skills, including cognitive ability and manual dexterity as well as social and personal skills (Green, 2020). This mix of skills is preferred given the need to balance the act of ensuring the continuation of 'business as usual' operations through practical skills while also looking ahead to the (behavioural) skills needed for business development and success in the longer term. An approximation of the required skills can be derived from the tasks that are bundled in an occupation. Particularly in the middle segment of the labour market, young people in vocational education and training (VET) may graduate in a field suitable for specific occupations. When they get tenured, they are likely to further develop their professional expertise on-the-job and by participating in short and long training courses (lifelong learning/developing).

In the previous subsection we have depicted the most important shortage occupations with the required educational background for the focus sectors. In this subsection we first reveal the most important other background characteristics and skills of workers. We then discuss the skill requirements per focus sector, with special attention to migrant workers.

\section{Background characteristics of workers in the focus sectors}

Below we discuss the desired characteristics of the wanted workers in terms of gender, age, non-western migrant background and part-time work. We specifically report the most salient outcomes for these characteristics in Table 7. We find that the metal industry and energy transition sectors of industry are male dominated, with low shares of young, migrant (non-western) and part-time workers. On the contrary, in the care sector many females are working part-time and do not have a migrant (non-western) background. Note that we use averages of all workers per focus sector to derive conclusions about the medium-skilled workers (mbo 4-level) in each sector.

Table 7: Background characteristics of workers other than skills in focus sectors

\begin{tabular}{|c|}
\hline $\begin{array}{l}\text { Metal industry } \\
\text { - very low share of female workers }(13 \%) \\
\text { - low share of young workers (17\%) } \\
\text { - very low share of part-time workers }(18 \%)\end{array}$ \\
\hline $\begin{array}{l}\text { Energy sector (energy transition) } \\
\text { - low share of female workers }(21 \%) \\
\text { - very low share of young workers }(13 \%) \\
\text { - low share of part-time workers }(22 \%)\end{array}$ \\
\hline $\begin{array}{l}\text { Construction sector (energy transition) } \\
\text { - very low share of female workers }(9 \%) \\
\text { - very low share of non-western migrant workers }(7 \%) \\
\text { - very low share of part-time workers }(17 \%)\end{array}$ \\
\hline $\begin{array}{l}\text { Care sector } \\
\text { - very high share of female workers }(77 \%) \\
\text { - low share of non-western migrant workers }(8 \%) \\
\text { - high share of part-time workers }(65 \%)\end{array}$ \\
\hline
\end{tabular}


Source: ROA/AIS

Note: The typology of low and high shares is based on a comparison with 20 other sectors of industry. The averages for the Netherlands are $47 \%, 26 \%, 11 \%, 49 \%$ for, respectively, female workers, young workers (up to 30 years old), non-western migrant workers (everyone with at least one parent born abroad, and whose origin is a non-Western country), part-time workers (working 35 hours or less per week)

\section{Example of sub-sector within energy transition sector: Technical installation sector}

The technical installation sector $(\mathrm{TI})$ is a transversal sector spanning across several domains of energy-transition industries. Mechanical technicians constitute most of the occupational employment in the installation sector. However, given that the labour market for mechanical technicians is larger than just the technical installation sector, mechanical technicians can work in related sectors as well. The TI sector is almost exclusively filled by men (98\%), with an average age of 41 years old in 2018 and an expected increase for the future years (Vermeulen et al., 2018). The group of workers over 55 is the largest.

\section{Training activities and skills of workers in the focus sectors}

Table 8 gives an impression of the relevance of training activities and the average workers' skills in the focus sectors. We evaluate the participation in short- and long-term training courses against other sectors of industry, as well as numeracy and language skills and the problemsolving ability in digital environments. The picture is rather mixed. The construction sector and to a lesser extent the metal sector stand out in low training needs and skill requirements for workers, contrary to the energy and the care sector sector. Again, note that we use averages of all workers per focus sector to derive conclusions about the mediumskilled workers at the mbo 4 level in each sector.

Table 8: Formal training activities and skills of workers in the focus sectors

Metal industry

- low participation in long-term training courses (8\%)

Energy sector (energy transition)

- high numeracy skills

- high problem-solving ability in digital environments

Construction sector (energy transition)

- low participation in short-term training courses (4\%)

- very low participation in long-term training courses (7\%)

- very low computer use

- low language skills

- low problem-solving ability in digital environments

Care sector

- high participation in short-term training courses (8\%)

- high computer use at work

Source: ROA/AIS

Note: The typology of low and high shares is based on a comparison with 20 other sectors of industry. The different skills in the Netherlands are therefore referred to as average. Workers' participation rates in short-term ( $<6$ months) and long-term ( $\geqq 6$ months) training courses in the Netherlands are $6 \%$ and $17 \%$, respectively 


\section{Skills requirements: Metal sector}

For technicians and metalworkers, CEDEFOP (2016) highlights four key skills, namely problem-solving, teamwork, lifelong learning and communication. Broader skills include cross-functional thinking, curiosity, and adaptability. Digitalisation is accelerating the changing composition of employment across jobs in manufacturing, particularly affecting middle-skilled jobs, such as maintenance and installation engineers, mechanical engineers, and metalworking. This occurs because digitalisation leads to increased automatisation of routine work which is concentrated in the middle of the skills distribution (European Commission, 2019).

\section{Example 1 of sub-sector within metal sector: Steel sector}

For the European Commission a study has been carried out to explore the skills needs of the steel sector (EASME, 2019). The study is based on a survey among industry experts, targeted workers in the steel industry and HR managers. Specialised manual profiles (e.g. steel shop operators, maintenance operators, rolling and casting operators, etc.) need solid knowledge of metallurgical and industrial processes relevant to steelmaking. Also new advanced technology skills on Key Enabling Technologies (nano- and biotechnology, photonics, materials) and green skills are important for the steel sector. More general skills requirements involve digital, language and team-building skills. Digital skills translate in the ability to use computers beyond company-specific software. Steel shop operators increasingly work remotely with respect to production lines and interactions need to be managed through digital remote access. The required digital skills go from the minimum knowledge of Microsoft Office and SAP, to software for production planning and scheduling, logistics and project management, to more specialised digital skills pertaining advanced practices such as 3D design and modelling (EASME, 2019).

Minimum Dutch language skills are becoming paramount to work in the metal sector with new machines, due to safety measures. It is necessary for technicians to be able to understand and interpret data computerised from a machine. Team building skills respond to the increasing diversity of the workforce, and the more subtle challenge of an ageing workforce not being adequately replaced by enough new hires. Given so, mentoring schemes need to be set in place to retain the knowledge and experience built and to pass it on to new hires. Team building skills ensure that teamwork functions better, especially in increasingly flexible working conditions where technical functions become more integrated among each other (EASME, 2019).

\section{Example 2 of sub-sector within metal sector: Machine tool industry}

The machine tool industry is one of the most central sub-sectors of the metal sector, constituting the backbone of every single metal manufacturing operation. It relates to all pillars of modern manufacturing. For this reason, it is worth exploring in depth this sub-category. Akyazi et al. (2020) developed a methodology to illustrate the present and near-future skill requirements for the machine tool sector professional profiles. The database with skills and competencies was based on the integration of data from multiple sources. The overall 
data served to identify the general and specific skills needed by the machine tool industry workforce in the future. In Annex 2 the general and specific skills are shown for the technical and green future skills in the machine tool Industry.

\section{Skills requirements: Energy transition sector}

The transformation needed from the energy sector to reduce the threat of climate change is enormous (Jacobsson \& Karltorp, 2012). When it comes to energy transition, the Netherlands is a leading European example in some areas. For example, in terms of embracing sustainability, the large R\&D-investments in smart wind energy projects combined with geographical configurations allow to benefit from growth in wind farm installations. Moreover, the number of solar panels has increased year-on-year since 2012, with a strong increase by over $40 \%$ since 2018 (CBS, 2019b). Ultimately, the advancements in sustainable construction are reflected also within the above average score of the Netherlands within the EU28 Eco-innovation index of 2019 (Saes \& van der Veen, 2019). The timely formation of specialised human capital is therefore of great importance in various ways. The Renewable Energy (RE) and energy transition sectors include different sub-sectors that are shown in Table 9.

Table 9: Specific occupations per sub-sector of Energy transition sector (not exclusively middle-segment occupations)

\begin{tabular}{|l|l|}
\hline Sub-sector of Energy transition sector & Occupations at all levels within sub-sector \\
\hline Wind energy & $\begin{array}{l}\text { Project developers; service technicians; data } \\
\text { analysts; electrical, computer, mechanical and } \\
\text { construction engineers }\end{array}$ \\
\hline Solar energy & $\begin{array}{l}\text { Photovoltaic and solar thermal system installers } \\
\text { and maintainers; building inspectors }\end{array}$ \\
\hline Hydropower & $\begin{array}{l}\text { Electrical and operations and maintenance } \\
\text { engineers; technicians; tradespersons; } \\
\text { sustainability specialists }\end{array}$ \\
\hline Bioenergy & $\begin{array}{l}\text { R\&D and design engineers; service technicians; } \\
\text { trainers }\end{array}$ \\
\hline
\end{tabular}

Source: ILO \& European Commission (2011)

Before delving into the specificities of three selected sub-sectors, there is a set of competencies that are transversally requested within the general energy transition sectors. The first broad set of skills needed in industry embracing sustainable development are known as 'green' skills or 'low carbon' skills (Jagger et al., 2012). These new skills are needed to face the uprising challenges of the energy transition sectors. Interviews with industry experts have revealed that a total of eight elements identify green skills. These are: waste skills, design skills, planning, procurement, and material skills, energy and water skills, communication skills, management skills, leadership and teamwork skills, problemsolving and critical thinking skills (Zubir et al., 2021). Energy skills were classified second by importance in the ranking of green skills. Green skills are transversally applicable and recurrent across renewable energy sectors. 
Table 10: Ranking of green skills most in demand by the energy transition sector

\begin{tabular}{|l|c|}
\hline Design skills & 1 \\
\hline Energy skills & 2 \\
\hline Client skills & 3 \\
\hline Leadership and management skills & 4 \\
\hline Community skills & 5 \\
\hline Construction skills & 6 \\
\hline Town and country planning skills & 7 \\
\hline Waste skills & 8 \\
\hline Procurement skills & 9 \\
\hline Landscape and environment skills & 10 \\
\hline Building management skills & 11 \\
\hline Financial skills & 12 \\
\hline Transport infrastructure skills & 13 \\
\hline
\end{tabular}

Source: Zubir et al. (2021)

Example 1 of sub-sector within energy transition sector: Sustainable construction industry

Bevan et al. (2020) identified a set of skills needed to adopt energy efficient improvements in buildings by local authority's energy teams. These are skills in energy management, communication, project management, basic IT and technical skills. Another study to assess the type of skills required in energy efficiency building construction was conducted in several Asian countries (Aliagha et al., 2014). Energy efficiency skills in this study that presumably require only vocational training at the medium-skill level refer to the competence to measure efficiency of heating and cooling units, the ability of solar photovoltaic panel design and installation, the competence to use energy efficiency diagnostic tools, and the skills in energy efficiency maintenance.

\section{Example 2 of sub-sector within energy transition sector: Wind industry ${ }^{12}$}

Professionals in the renewable energy sector, such as the wind energy industry, are expected to possess specific technical skills. More broadly, they also need sector spanning competencies such as social and environmental awareness (Malamatenios, 2016), and a solid grasp of sustainability concepts (Davidson et al., 2010), besides more general skills such as problem-solving and entrepreneurial skills (Lucas et al., 2018). A survey from the European Wind Energy Technology Platform (TPWind) has found that "problem solving aptitude" is among the most important skill for employers, followed by technical academic credentials, technical expertise, commercial experience and, ultimately, the understanding of R\&D processes (Fitch-Roy et al., 2013).

According to several interviews conducted by Jacobsson and Karltorp (2012) with experts and professors in engineering, the main bottleneck in the wind industry is a shortage of electrical engineers. The two main categories of skills demanded in the wind energy industry can be simply categorised into two dimensions: 'Deep' and 'Integrated' competencies. Deep

12 A literature review on wind and solar energy technologies has shown that skill shortages in these specific technical sectors are consequence of a multitude of factors, mostly stemming from scarcity of required practical hands-on training and poor problem-solving skills that are not sufficiently tackled in higher education contexts (Lucas et al., 2018). Note also that many sources in this subsection are rather old (pre-2016). Nevertheless, we think they are still useful. 
competencies refer to engineers with specific added-value competences within a given discipline, which translates into the need for mechanical engineering, electrical engineering, engineering physics, software and civil engineering. Integrated competencies combine several knowledge fields in a novel way which are normally taught separately. Engineering degrees are the most requested to fill skill shortages in the wind industry.

In the wind industry, apart from engineers, specialised turbine technicians are also needed (Malmatenios, 2016). This finding corroborates the need for mbo level-4 graduates and elucidates the type of specific skills required from them that are exclusive given their intermediate level of technical skills. The mbo level-4 workers are needed in roles that display less task complexity compared to engineering graduates, namely in operation and maintenance (O\&M) functions. O\&M employment requirements entail manufacturing, fabrication, construction, site development, installation, besides explicit operations and maintenance.

According to Cameron and van der Zwaan (2015), the competencies most requested for mbo level-4 workers in the wind and solar energy technology industry concern the domain of project management, where technical knowledge is prerequisite in so far it fulfils the objective of guaranteeing continuation of operations, maintenance and general business management tasks within larger more technical projects.

\section{Skills requirements: healthcare sector}

A recent report by Avontuur and Otten (2021) provides many figures on (asylum) migration and the healthcare sector in the Netherlands. This shows that there are shortages in the labour market for many sub-sectors and professions in the healthcare sector. This large sector falls apart into care (hospitals, mental healthcare, general practitioners) and welfare sectors (domestic care, care for the disabled, youth care, social work) in which different key occupations can be found. The largest shortages in the short and long term are expected for healthcare assistants (HCA) at the various levels below mbo 4-level (verzorgende mbo 3, helpende zorg \& welzijn mbo 2, zorghulp mbo 1), nurses (verpleegkundigen mbo 4 ), and specialised nurses and midwives at bachelor level (verlos- en verpleegkunde hbo 6). For the nurses in the middle segment of the labour market as defined in Section 3.1 of this report (verpleegkundige mbo 4), the shortages amount to 11,700 in 2022 and are expected to increase to 14,500 in $2030 .{ }^{13}$ Nurses can be employed in the care as well as the welfare sector and those with an mbo 4-level qualification are more or less equally divided between the two sectors. ${ }^{14}$ Nurses at bachelor level (hbo verpleegkunde) are more specialised than nurses at the mbo 4-level, but some specialisation is also possible for nurses with an mbo-4 level qualification (e.g. surgery assistants). ${ }^{15}$

Nursing professionals are the occupation with the highest reported shortages across European countries (European Commission, 2020a). A way to overcome these shortages is

13 These shortages are based on a scenario that only partially takes into account the COVID-19 crisis. For example, the second and third waves of contamination in 2020 and 2021 are not taken into account.

14 Information retrieved from https://roa.nl/research/research-projects/project-onderwijs-arbeidsmarkt-poa.

15 See for example https://www.olvg.nl/opleiding-tot-operatieassistent. 
to encourage the staffing of HCSa, also referred to more simply as Nursing Assistant, which constitutes a profession that is becoming increasingly important and is often deployed to take over tasks from nurses and support medical staff in providing care (Schäfer et al., 2016). The main duties and core tasks of HCA consist of monitoring and measuring patients' vital signs, providing non-medical care and supporting other health professionals, while applying safety, quality and hygiene techniques (Schäfer et al., 2016). There is also a widely reported and severe shortage of HCAs in the European context and other major developed countries (European Commission, 2020), which may be exacerbated by the recent COVID-19 pandemic and health crisis.

The most cited skill for nurses and HCAs is the Dutch language and basic understanding of Dutch work culture. V\&VN, the largest professional association for nurses in the Netherlands, reported that language barriers constitute not only problems of appropriate work integration, but also a danger for quality of patient care: patients need to be able to communicate to the caregiver and vice versa; furthermore, language barriers also limit the ability of nurses and HCAs to question the professional opinion of doctors if necessary, which is a prerequisite for ensuring the best possible patient care (de Veer et al., 2004; Kodoth \& Jacob, 2013). This may be an explanation for the low employment share of migrants and workers with a migrant background in the healthcare sector, in particular among nurses (ACVZ, 2021). More than 15\% of the workforce in the healthcare sector have a migrant background (including second generation), against almost $25 \%$ of all workers in the Netherlands. Only $6 \%$ of the nurses are born outside the Netherlands, which is much lower than in most other developed countries (ACVZ, 2021).

\section{Skills requirements: General considerations for migrants}

In general, social, culture and language skills seem to be very important for migrants to get a job and to stay in the host country. Oomes et al. (2019) emphasise the importance of Dutch language and culture skills for migrants that would like to work in healthcare occupations, and the lower importance of these skills in ICT and technical occupations, especially if they master the English language. Australian employers value interpersonal competencies (i.e., strong teamwork and people management skills, and personality and values) alongside hard skills (i.e., recognised qualifications, unique specialisation, and unique industry experience) when assessing skilled migrants for recruitment (Wright \& Constantin, 2021).

Ette et al., (2016) show that in particular language skills are among the best predictors of migrants' intention to permanently settle in the new country. The study accounted for permanent settlement intentions of Germany's most recent labour migrants from nonEuropean countries on the basis of new administrative data. Three main factors explained their chances of permanent settlement intentions: language skills, the family context and the legal framework (mind that economic reasons were considered of lesser importance). It stands out that among these factors, also the ability for newcomers to further enhance their (language) skills was a valid reason to the decision of pursuing permanent residency, providing empirical evidence for the positive effects of investments in language courses. Geurts \& Lubbers (2017) analyse with Dutch data the impact of the intention to settle on language proficiency and not 
the other way around as in the previous study. They investigate the impact of a change in migrants' intention to stay at two points in time during their first years in the Netherlands. The empirical results are mixed. While they find that "not having a permanent intention to stay will impact investments regarding language proficiency negatively" (p. 1056), they also find some evidence that a change from a temporary or permanent residence intention to a circular migration intention can improve Dutch language proficiency.

Sub-question 1: In which sectors of the middle segment of the Dutch labour market are there shortages of employees? Which sectors are included in the study, and why?

Answer:

- Based on an analysis of the largest staffing bottlenecks for employers up to 2024, it can be concluded which sectors of industry would benefit most from a supportive migration policy aimed at the middle segment of the labour market. This middle segment comprises all persons who have obtained their diploma at the level of upper secondary vocational education, i.e. at mbo 4-level.

- The following three sectors face the largest labour market shortages at this education level: metal industry, energy transition (including construction and energy) and (health)care. These sectors are called the focus sectors throughout this report.

- There is quite some overlap between the metal and energy transition sectors (energy and construction) with respect to the most prominent shortage occupations and types of education in the middle segment of the three focus sectors. Within these sectors, the broad key occupations Maintenance and installation engineers, Electricians and electronics mechanics, Technicians in construction and nature are likely to face large staffing bottlenecks up to 2024. The same holds for the mbo 4level types of education in these sectors: Mechanical engineering and metalworking, Electrical and installation engineering, Construction and infrastructure.

- Furthermore, within the broad shortage occupations of the metal and energy transition sectors, specific occupations can be distinguished for which employers now face large staffing bottlenecks. In the short run, this situation is likely to continue for these occupations.

- In contrast to the metal sector and the energy transition sector, in the healthcare sector nurses are the only key occupation in the middle segment of the labour market with large staffing bottlenecks. This occupation is related to the mbo 4-level education nursing and medical support. Nurses are more or less equally employed in the care and the welfare sector. Some specialisation is possible at the mbo 4level, although for real specialisation further education at bachelor level is required.

Sub-question 2: What are the desired characteristics of the sought-after workers (per focus sector), such as: demographics, professional education, expertise, skills and/or other?

Answer:

- Working in specific technical or care occupations does require specific skills, but our literature review also reveals that more general social or interpersonal and culture or language skills are often as least as important. Migrant workers are clearly underrepresented in the healthcare sector, as well as in the construction sector. 
- There are many specific occupations requiring much specialisation in the energy transition sector, which may explain that the required skills (numeracy and problem-solving) skills in the energy sector are above average, contrary to the required skills in the construction sector. Workers In the metal sector typically participate less than average in (long-term) training activities.

- There are many females working in part-time jobs in the healthcare sector, contrary to the metal and energy transition sectors. Young workers (up to 30 years old) are underrepresented in the metal and energy sectors of industry.

- Bear in mind that the above description of the background characteristics of workers and the skill requirements in the focus sectors are mostly not known exactly for employees at mbo 4-level, but largely apply to the average worker per focus sector.

- In addition, the metal sector and in particular the energy transition sector comprise a large number of sub-sectors. Within the metal sector we can distinguish, among other sub-sectors, the steel sector and the machine tool sector. Within the energy transition sector, the variety of subsectors is probably even greater, with, for example, the energy sectors wind, solar, hydropower, bio-energy and the construction sectors technical installation and sustainable construction (among others). Note also that not all economic activities within these sub-sectors are necessarily related to the energy transition. 


\section{Priority supply from EEA+ countries and beyond}

Having identified that the middle segment of the Dutch labour market experiences shortages in the healthcare, metal and energy transition sectors and having explained desired characteristics of the sought-after workers, this section examines potential sources of international labour. Moreover, it focuses specifically on EEA+ countries as nationals from these countries should be prioritised to fill Dutch vacancies. We furthermore summarise characteristics of migrants in the Netherlands who originate from different parts of the world. In doing so, we aim to answer the third set of sub-questions: Is there a sufficient priority supply for medium-skilled workers in the focus sectors in the EEA and/or outside the EEA? If so, which supply and where? Why do the Dutch demand and the foreign supply not match? In Section 4.1 we discuss labour shortages and oversupply in EEA+ countries. In Section 4.2 and Section 4.3 we further discuss the potential supply of EU nationals and TCNs, respectively. In Section 4.4 we look at the limitations to match Dutch demand and foreign supply.

\subsection{Labour shortages and oversupply in EEA+ countries}

The European Commission (2020a) provides an overview of the deficits and surpluses in the various EEA+ countries (plus the United Kingdom) ${ }^{16}$ based on analyses of data submitted by the national coordinating offices (NCO's) of the European Employment Service (EURES) and supplementary sources such as the European Labour Force Survey. ${ }^{17}$ Due to the COVID-19 pandemic, the number of vacancies registered with Public Employment Services (PES) fell drastically in the first half of 2020 compared to the same period in 2019. The decline in vacancies affected all major skill groups, strongest in hospitality and least in health. Skills shortages requiring personal intervention (e.g. healthcare related) as well as technical (STEM: scientific, technological, engineering or mathematical expertise) skills shortages were widespread and severe. Shortages of specific software occupations were identified in 20 of the 30 countries/regions covered in this report. Healthcare occupations including doctors and nurses - figured more prominently than in previous years. Nurses were even ranked first, and the occupation of HCAs appeared for the first time as an occupation with a shortage. In contrast, clerical, unskilled and some graduate occupations (requiring routine tasks or general expertise in a branch of the humanities, e.g. journalist or sociologists) had an excess supply. Thirteen widespread shortage occupations had matching opportunities between countries in Europe. In the third quarter of 2020, there has been a significant recovery in vacancies, especially in the healthcare sector. ${ }^{18}$

The European Commission (2020) concludes that "in thirteen of the most widely reported shortage occupations, there is a surplus of qualified workers in mainly one or two other countries/regions - thus creating a (limited number of) cross-border matching possibilities" (p.6). Based on the above source (and the previous editions of this source) it thus appears that

16 Austria, France and Iceland are missing. In the case of Belgium, three Belgian regions participated (the Flemish, Brussels-capital and Walloon Region).

17 The NCO's have used various sources of information used to assess the labour market imbalances, e.g. administrative and survey data from the Public Employment Services (PES), third party surveys and national occupational forecasts.

18 This means that the report does not take into account the effects on the labour market of the later waves of the COVID-19 pandemic. 
for occupations that are consistently classified by most countries/regions as shortage occupations, the possibilities to solve these shortages with cross-border mobility are limited. Therefore, the European Commission concludes that there are only a few possibilities for cross-border matching of shortage and surplus occupations. Opportunities for crossborder mobility in shortage occupations are only considered if there are at least three countries with a surplus for these occupations. Such possibilities for cross-border mobility occur only for cooks, waiters, bricklayers and cleaners. ${ }^{19}$ Table 11 shows that for the Netherlands there are only a few EEA+ countries with matching possibilities for the shortage occupations in the Netherlands. ${ }^{20}$ Since there seems to be hardly any oversupply in the EEA+ countries for the shortage occupations in the Netherlands, including those related to the three focus sectors of this report, it is probably very difficult to recruit from the priority supply. ${ }^{21}$ We can conclude that it may be necessary to attract workers from third countries to fill the vacancies for these occupations.

Table 11: Potential cross-border matching of shortage and surplus occupations in the EEA+ countries (plus UK), ranked by most widespread shortage occupations that are relevant to the Netherlands

\begin{tabular}{|l|l|l|}
\hline $\begin{array}{l}\text { Ranking of shortage } \\
\text { occupations (out of 13) } \\
\text { across Europe ánd the } \\
\text { Netherlands }\end{array}$ & \multicolumn{2}{|c|}{ Countries/regions with: } \\
\cline { 2 - 3 } 6. Electricians & Shortages & Surpluses \\
\hline $\begin{array}{l}\text { 7. Agricultural / industrial } \\
\text { mechanics }\end{array}$ & $\begin{array}{l}\text { Belgium-Wallonia, Belgium-Flanders, } \\
\text { Germany, Denmark, Finland, Estonia, Latvia, } \\
\text { Netherlands, Norway, Portugal, Slovenia }\end{array}$ & $\begin{array}{l}\text { Belgium-Wallonia, Belgium-Flanders, Belgium- } \\
\text { Brussels Germany, Estonia, Netherlands, } \\
\text { Norway, Portugal, Sweden, Slowania }\end{array}$ \\
\hline 8. Civil engineers & $\begin{array}{l}\text { Belgium-Wallonia, Belgium-Flanders, } \\
\text { Switzerland, Germany, Ireland, Netherlands, } \\
\text { Norway, Sweden, Slowania, United Kingdom }\end{array}$ & Portugal \\
\hline 10. Healthcare professionals & $\begin{array}{l}\text { Denmark, Estonia, Spain, Finald, Luxembourg, } \\
\text { Netherlands, Norway, Romania, Slowania }\end{array}$ & Lithuania \\
\hline
\end{tabular}

Source: EC (2020), selected occupations

\subsection{Supply of EEA+ nationals}

Within the EU, workers from EEA+ countries enjoy the right to free movement. This implies that in principle there are no legal obstacles for workers at the upper secondary vocational level to enter the Dutch labour market. Nevertheless, intra-European labour migration is still relatively low (Dittrich \& Spath, 2016). Scholars and policy-makers are increasingly interested

19 Remarkably, some occupations in the hospitality sector (such as cook and waiter) were classified as shortage occupations despite the pandemic.

20 Note that the shortage occupations listed for the Netherlands (Electricians, Agricultural / industrial mechanics, Civil engineers, Healthcare professionals) are not exclusively limited to the medium-skilled workers and differ from the terminology used in the previous section.

21 See Sub-section 3.1 of this report for a more extensive list of shortage occupations in the metal sector, the energy transition sector and the healthcare sector of the Netherlands. 
in understanding why this is the case and the body of literature on intra-European migration is increasing. Nevertheless, medium-skilled migration in general and in the three focus sectors specifically, is hardly covered by the available literature.

\section{Trends and flows}

The European Commission's Annual Reports on Intra-EU Labour Mobility (written by FriesTersch et al., 2017, 2018, 2019, 2020, 2021) provide a good overview of the general trends regarding intra-EEA+ migration. These reports were compiled using Eurostat data. According to Fries-Tersch et al. (2021), the number of EEA+ citizens of working age residing in different $E E A+$ countries was around 13 million in 2019 , showing an increase of $1.2 \%$ in comparison to 2018. However, when looking only at the EU-27 countries (excluding the United Kingdom after Brexit) there is an increase of 3.2\% compared to 2018 (Fries-Tersch et al., 2021). The main countries of destination for intra-EEA+ migrants in 2019 were Germany and the UK (see figure below). The Netherlands hosts 447,000 movers in the country (Fries-Tersch et al., 2021).

Figure 1: Stocks of EU-28 movers in individual countries, in absolute numbers $(1,000 \mathrm{~s})$ and as a percentage of the total working-age population in the country, 2019

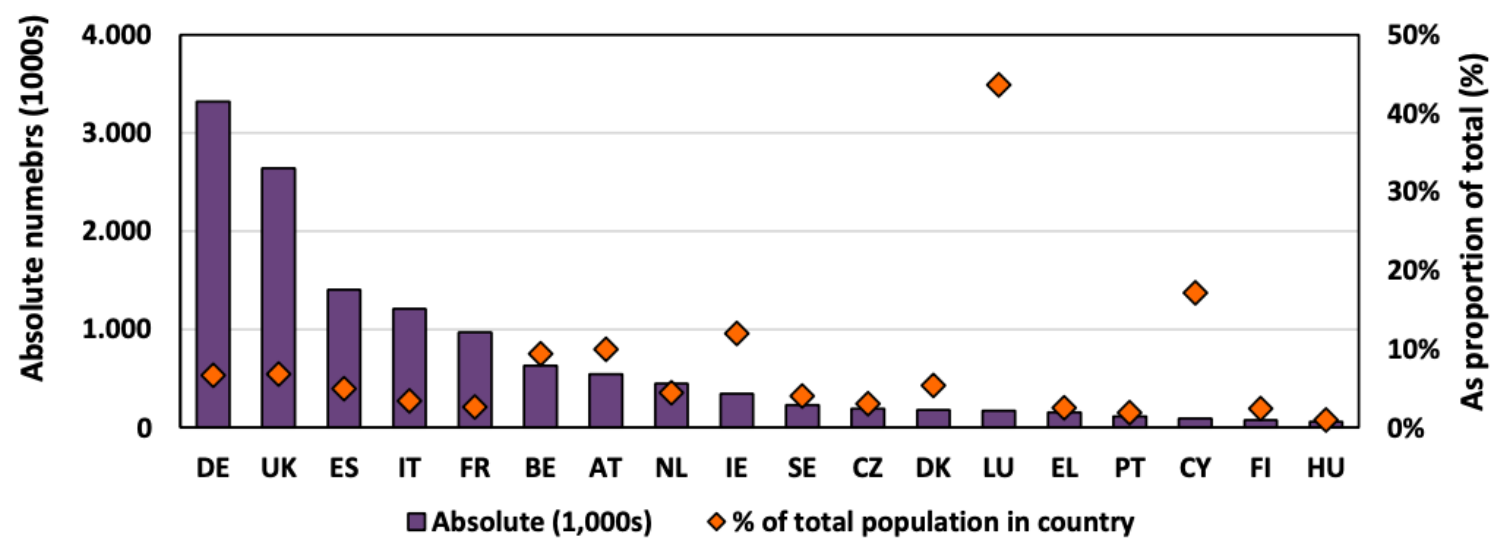

PROVISIONAL DATA: FRANCE. ESTIMATED NUMBERS: IRELAND. THE LEFT Y-AXIS DISPLAYS THE SCALE FOR ABSOLUTE NUMBERS OF MOVERS IN 1 000S;THE RIGHT Y-AXIS THE MOVERS AS A PERCENTAGE OF THE TOTAL WORKING-AGE POPULATION IN THE COUNTRY.

TO IMPROVE READABILITY THE FOLLOWING COUNTRIES, WITH STOCKS OF LESS THAN 50 000, ARE OMITTED FROM THE GRAPH: BULGARIA, CROATIA, ESTONIA, LATVIA, LITHUANIA, MALTA, POLAND, ROMANIA, SLOVAKIA AND SLOVENIA,

SOURCE: EUROSTAT DATA ON POPULATION BY CITIZENSHIP AND AGE GROUP [MIGR_POP1CTZ] (EXTRACTED MAY 2020), MILIEU CALCULATIONS.

Source: Friesch-Tersch et al., 2021 (Eurostat data)

The European Commission's Intra-EU Labour Mobility reports from previous years identify the same countries as the main destination countries for intra-EEA+ migrants (Fries-Tersch et al., 2017, 2018, 2020). Romania, Poland, Italy, Portugal, and Bulgaria are the top 5 sending countries (European Commission, 2020b; Fries-Tersch et al., 2019, 2020). Marchand, Fajth and Siegel (2019) give a detailed overview of data sources to understand intra-EEA+ migration and identify remaining gaps. They conclude that "intra-EU migration seems to receive less attention in European statistics than immigration from outside the EU" (Marchand et al., 2019, p.94). 
According to an OECD policy brief on Germany (2018), the supply of medium- and lowskilled workers from the EU is likely to decrease in the long term, due to the EEA's shrinking working-age population. The aging of the working-age population is a trend that is seen in many economies, but is especially concerning in Central and Eastern European countries (Kasnauskiene \& Michnevic, 2017, p. 95; Thalassinos et al., 2019). The shortages that this decrease will create in the longer term can be mitigated by "well-managed labour migration" from third countries (OECD, 2018, p. 1). Mortera-Martinez and Oppenheim (2018) suggest that Europe will be in need of labour migrants in the future to "supplement its aging labour force" (p. 2). Research by Marx and Schouteten (2020) shows that the aging population is also an issue for the Netherlands, and that labour migration could be a part of the solution to rejuvenate the Dutch workforce (see also Het Kenniscentrum Arbeidsmigranten, 2021).

Other factors also play a role in the future of intra-EEA+ mobility. According to Fries-Tersch et al. (2021), the withdrawal of the UK from the EU will impact intra-EU migration. Although migration from EU-27 countries has already steadily been declining since the vote for Brexit in 2016, this will decrease even further after Brexit. However, the number of new movers to the UK and vice versa depends on the migration rules in both the UK and the EU Member states. Additionally, the report mentions the COVID-19 pandemic as a barrier to intra-EEA+ mobility. Apart from the immediate effect of the pandemic on mobility, FriesTersch et al. (2021, p. 74) mention that the "longer-term economic hardship faced by many industries" will negatively influence intra-EEA+ migration.

\section{Characteristics of intra-EU migrants}

According to the European Commission's Annual Report on Intra-EU Labour Mobility 2020 (Fries-Tersch et al., 2021), the EU-27 countries' foreign population consisted of 25,262,000 persons in 2020, of which $41 \%$ were EU-28 nationals, $58.3 \%$ TCNs, and $0.6 \%$ EFTA nationals. The authors state that working-age individuals have a much higher share among EU-28 movers (73\%) than the overall population (58\%). Particularly people aged 65 and older do not make up a big share of the migrant population. The most significant difference is seen in the younger working-age groups: "the proportion of 20-34-year-olds among EU-28 movers is much higher than among nationals" (Fries-Tersch et al., 2021, p. 32).

Furthermore, although the share of highly skilled migrants (typically seen as those with tertiary education) has increased significantly from $32 \%$ in 2011 to $36 \%$ in 2019 , medium-skilled migrants (who usually work in jobs that require vocational education and training, but not at the tertiary level) make up the largest part of the total intra-EEA+ migrants, but the share has decreased from $42 \%$ to $41 \%$. Finally, the share of low-skilled migrants (usually working in jobs that do not require qualifications) has decreased from $26 \%$ to $22 \%$ (FriesTersch et al., 2021). Marchand et al (2019) find that background information on migrants like data on education, skills and occupation are often lacking and recommend including items on these matters in EU-wide surveys that are implemented more regularly. The literature review did not identify literature on the three focus sectors specifically. 


\section{Drivers}

Benton and Petrovic (2013, p. 12), state that "opportunity differentials are at the heart of most migration". Where potential gains (e.g. increased earnings, career development opportunities) are weighed against potential costs (e.g. separation from family, adapting to a new environment) people are also influenced by external factors. Since intra-EU mobility has been made easy by the lack of visa requirements and work permits, the barriers are lower, and more people are inclined to migrate. According to the authors, the choice of destination is shaped by various social and economic factors. The paper distinguishes between four main drivers of intra-EEA+ migration: employment, education, family, and retirement (Benton and Petrovic, 2013). A study by Dubow et al. (2019) researching the determinants of intra-EEA+ migration of both EEA+ and TCN migrants shows a similar distinction. The paper states that common drivers of intra-EEA+ migration include the purpose of employment or studies, family and love reasons, lifestyle reasons, and other reasons. Possible other reasons for migration include access to social security, other economic factors and opportunities, political dissatisfaction and social tensions in the country of origin, a return to the roots or securing permanent residence (Dubow et al., 2019). According to the authors, it is important to note that mobility decisions are "typically based on multiple motivations, there is rarely a single "determinant" of an individual's intra-EEA+ mobility decision" (p. 107). Vargas-Silva (2019) furthermore explains that intra-EEA+ migration is more flexible, for example with regard to remigration and return. Intra-EEA+ migration is therefore often less strategic or more 'openended' than immigration into EEA+ countries from third countries, since it is relatively easy to travel back and forth between home and host country.

The return plans of EEA+ migrants are more open-ended compared to those of non-EEA+ migrants. In a context of freedom of movement, where recurring migrations are easy, there is less weight put into strategic thinking on issues related to the length of stay and the likelihood of return. EEA+ migrants therefore do not plan their migration trajectories in much detail. These factors are major strategic decisions for non-EEA+ migrants, particularly undocumented ones, given the legal and practical difficulties of subsequent migration.

\subsection{Supply of TCNs from EEA+ countries}

This section includes information on the intra-EEA+ mobility from TCNs. Similar to the previous sub-section, the literature search did not identify many sources covering medium-skilled migration in general and in the three focus sectors specifically.

\section{Origin}

The Intra-EU Labour Mobility report by Friesch-Tersch et al. (2021) also includes information on the labour migration of TCNs in the EEA+ countries. The majority of TCN migrants within the EEA+ are from non-EU countries in Europe (31\% in 2016), the second largest group of migrants that have moved from North Africa and Near- and Middle East (28\%), followed by migrants from Sub-Saharan Africa, East and South Asia and Latin America (all between 10\% and $16 \%)$. 


\section{Trends}

As for the intra-EEA+ mobility of TCNs, according to Dello lacono et al. (2021, p. 31), "there has been a gradual increase in the mobility of TCN migrants within the EU, both in relative and absolute terms". According to the report, the share of intra-EU TCN migrants in relation to the total of TCN migrants in the EEA+ grew from $0.03 \%$ to $0.26 \%$ between 1996 and 2016, which means that there has been an overall increase in the intra-EEA+ mobility of TCN migrants (Dello lacono et al., 2021). A new, increasing trend is the intra-EEA+ posting of TCN workers (Lens et al, 2021). According to Dello lacono et al. (2020), most TCN migrants' intra-EEA+ mobility occurs between neighbouring countries. For example, most TCNs in Belgium previously resided in the Netherlands (28\%) and France (21\%). According to the ACVZ (2019), TCN residence permits in the Netherlands consist mostly of family reunification $(30 \%)$, asylum (27\%), study (18\%) and work (17\%) permits.

\section{Skills}

The Atlas of Migration (2021) includes statistics on the educational attainment of TCNs in 2019, both in the EEA+ as a whole and in the Netherlands. These can be seen in the figure below. The figure reveals that the share of highly skilled TCNs in the Netherlands is almost 13 percentage points larger than on average in the EU, whereas the shares of low-skilled and medium-skilled TCNs are below average in the Dutch population ( 8 and 5 percentage points, respectively)

Figure 2: Educational attainment of TCNs in the EU \& NL, in percentages of 25-64 years old population, 2019

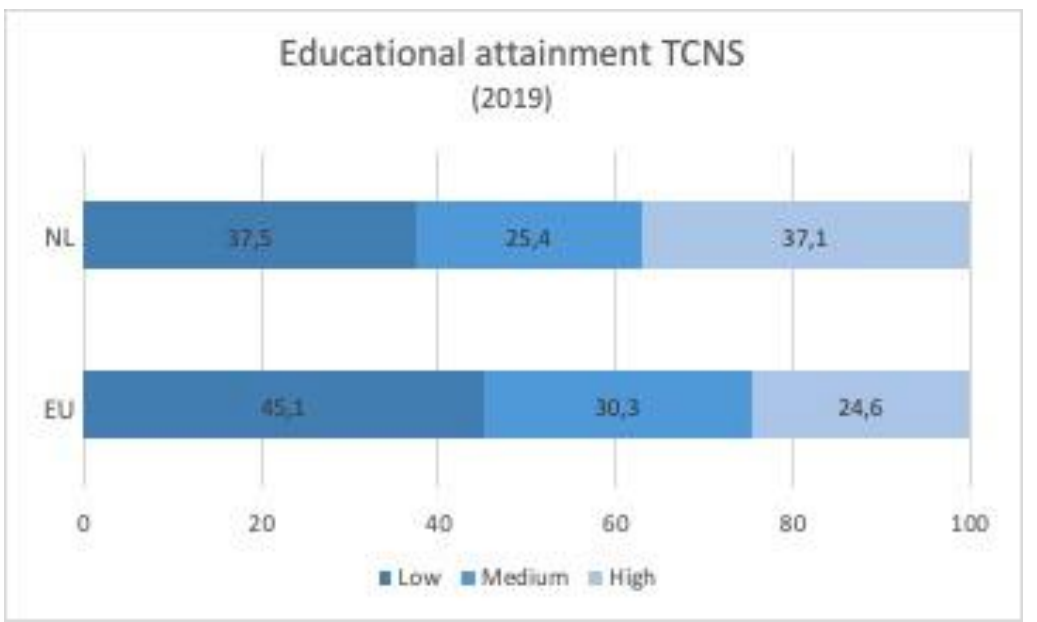

Source: Atlas of Migration, 2021 (Eurostat data)

Individuals from third countries residing in other EEA+ countries, for example Germany, are at a higher risk to be unemployed even if they are medium-, or high-skilled (Mayer \& Clemens, 2021). This suggests that facilitating the movement of TCNs within EEA+countries could result in a better match of demand and supply (De Lange \& Groenendijk, 2021). Mapping the intra-EEA+ mobility of TCNs can be difficult since the previous country of residence is rarely included in statistics (Marchand et al, 2019). 


\subsection{Migration to the Netherlands}

\section{Supply from EEA+ countries}

In the Netherlands in 2017, the total number of jobs filled by a foreign worker was 838,000 (CBS, 2019a). About half of the labour migrant population in the Netherlands comes from other European countries (SZW, 2021). According to the most recent statistics available via the Statistics Netherlands (CBS), foreign-born workers most often came from Poland (34.5\%), Germany (26.0\%) and Romania (7.5\%) in 2019 (CBS, 2020). These three groups account for half of all EU-born migrants in the Netherlands (see Table 12 below).

Table 12: Jobs filled in the Netherlands by foreign-born workers from the top-10 EU countries, 2019

\begin{tabular}{|c|c|c|c|}
\hline Country & $\begin{array}{r}\text { Absolute } \\
\text { numbers } \\
(x 1,000)\end{array}$ & Percentage & $\begin{array}{l}\text { Percentage } \\
\text { cumulative }\end{array}$ \\
\hline 1. Poland & 199.6 & $34.5 \%$ & $34.5 \%$ \\
\hline 2. Germany & 43.5 & $26.0 \%$ & $42.0 \%$ \\
\hline 3. Romania & 43.0 & $7.5 \%$ & $49.4 \%$ \\
\hline 4. Belgium & 28.5 & $7.4 \%$ & $54.3 \%$ \\
\hline 5. United Kingdom ${ }^{22}$ & 23.2 & $4.9 \%$ & $58.3 \%$ \\
\hline 6. Bulgaria & 20.8 & $4.0 \%$ & $61.9 \%$ \\
\hline 7. Italy & 19.1 & $3.6 \%$ & $65.2 \%$ \\
\hline 8. Spain & 14.3 & $3.3 \%$ & $67.7 \%$ \\
\hline 9. France & 12.9 & $2.5 \%$ & $69.9 \%$ \\
\hline 10. Portugal & 12.3 & $2.2 \%$ & $72.0 \%$ \\
\hline 11. Other EU countries & 161.2 & $28.0 \%$ & $100.0 \%$ \\
\hline $\begin{array}{l}\text { Total employment of foreign-born } \\
\text { workers }\end{array}$ & 578.4 & $100.0 \%$ & \\
\hline
\end{tabular}

Source: CBS (2019)

The share of low- and medium-skilled migrants has decreased in the Netherlands between 2011 and 2019 with 8 percentage points for the low-skilled and 5 percentage points for the medium-skilled, whereas the share of highly skilled migrants has increased with around 14 percentage points (Fries-Tersch et al., 2021). A recent research project by Het Kenniscentrum Arbeidsmigranten (2021) on the housing, work and living conditions of labour migrants in the Netherlands identifies economic and work-related factors to be among the most important reasons for intra-EEA+ migration to the 
Netherlands. Labour migrants often work below their educational level in the Netherlands, which is especially true for Eastern European migrants (ibid.). This phenomenon is known as underemployment, over-qualification or brain waste leading to the "misallocation of [already] scarce human capital" (Galgóczi, Leschke \& Watt, 2016, p.8). When focusing on the three focus sectors in the Netherlands, Heyma et al. (2008) states that around $11 \%$ of the long-term migrants from Central and Eastern Europe (CEE) staying in the Netherlands were employed in the healthcare sector; for the electricity and water sector this share is around $1 \%$. The report does not mention CEE migrants working in other fields in the energy (transition) sector, nor any migrants working in the metal sector. About $9 \%$ of the long-term migrants were employed in the manufacturing industry of the Netherlands, which includes the metal sector of industry. Temporary migrants work most often for temporary work agencies (48\%) and in the agricultural sector (23\%). According to Heyma et al. (2018) 371 thousand labour migrants from CEE countries were working in the Netherlands in $2016,49 \%$ of them as temporary workers. Almost one in twenty jobs in the Netherlands in 2016 was held by a labour migrant from Central or Eastern Europe. These labour migrants are mainly active in the south and west of the Netherlands and particularly in agriculture and horticulture, business services, logistics, wholesale trade, the food industry and the metal industry.

\section{Supply from third countries}

In 2017, $15.0 \%$ of all migrant workers in the Netherlands came from North or South America, 14\% from Asia, 10.7\% from Africa and 10.1\% from other European countries that are not members of the EEA+ countries (CBS, 2019a). With regard to the supply from third countries, we have identified sources covering Northern Africa, the Middle East, Asia and the Pacific and Latin America and the Caribbean. Again, the literature search did not identify many sources covering medium-skilled migration in general and in the three focus sectors specifically.

Figure 3: Foreign workers' jobs in the Netherlands by origin, percentage of total foreign workers' jobs, 2017

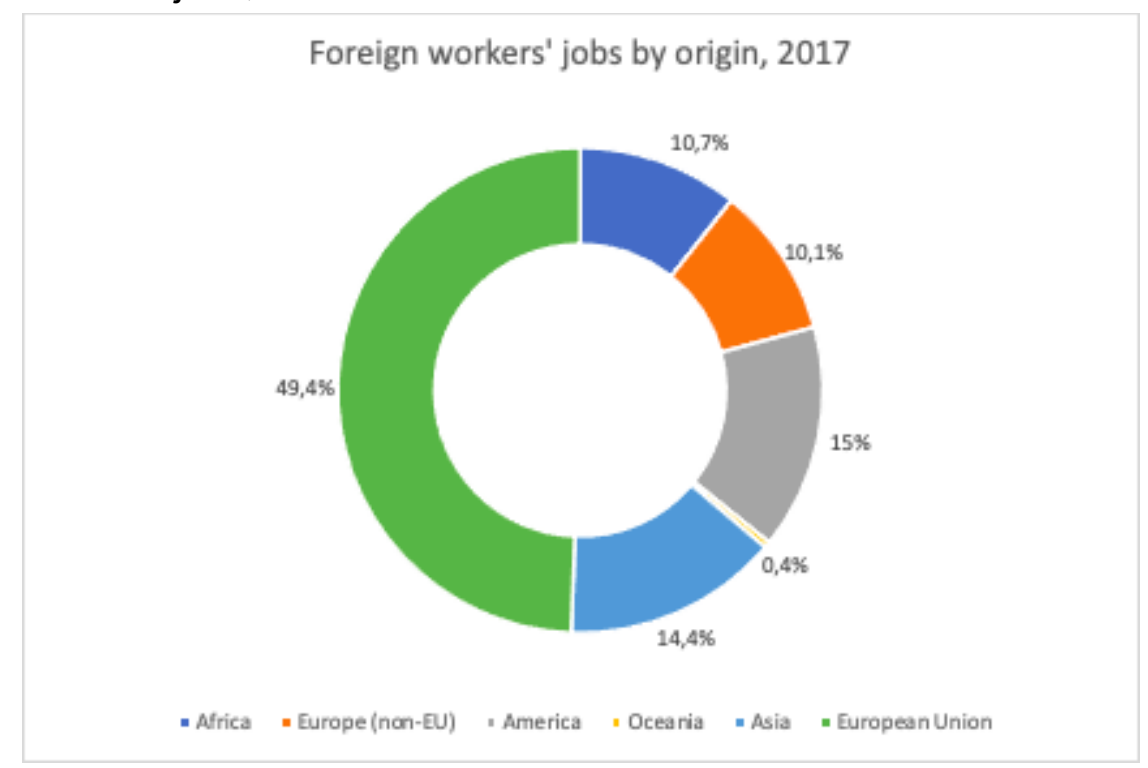

Source: CBS (2019) 
Research by Oomes et al. (2019) suggest that there is a strong potential from Northern Africa and the Middle East to fill skills shortages on the European and Dutch labour market, especially when it comes to medium and higher vocational professions including in the focus sectors of this report (i.e. engineering and health). It is expected that individuals from Africa and the Middle East will be interested in working abroad due to high unemployment especially among younger generations, women and tertiary educated individuals. In addition, demographic trends in African countries are opposite to those of Europe. While the European population is aging and shrinking, the African population is growing and getting younger, translating into a growing potential labour pool. Case studies on Tunisia, Jordan and Nigeria suggest that there are many individuals specialising in engineering and health related fields, but acknowledge that the quality of education might not always be up to European or Dutch standards (Oomes et al., 2019).

Although the study by Oomes et al. (2019) states that a growing African population will create a potential labour pool, other research suggests that this is only true to a certain extent. According to Ezeh et al. (2020), the population growth all over the world will slow down due to higher educational attainment and increasing access to contraception. This could mean that this potential labour pool is only a 'short-term' solution, as the report states that the global population will be at its peak in 2064, and will start declining after.

Khoudja (2018) finds that Moroccan (and Turkish) migrants are more likely to experience underemployment, arguably because of the limited transferability of foreign qualifications to the Netherlands. In comparison to Dutch degrees, foreign degrees are associated with lower labour market outcomes especially for migrant women (ibid.). Research on Germany shows a similar picture. Migrants are more likely to be unemployed or receive lower salaries compared to natives. TCNs are most disadvantaged compared to EEA+ and German nationals, even if they obtained higher or vocational education (Mayer \& Clemens, 2021). In addition, there is a significant difference between migrant men and women. Migrant women from third countries are "more likely to be over-qualified for their job and less likely to be in employment" (European Commission, 2018). This also includes refugee women (Liebig \& Tronstad, 2018). Similarly, intra-EEA+ migrant women also have lower employment outcomes than their male counterparts (Fries-Tersch, 2021). Mayer and Clemens (2021) recommend strengthening the labour market position of migrant women, for example by approaching them directly through information campaigns and by increasing the compatibility of work and family life. Some examples of efforts to help migrant women integrate in the labour market can be found below. 


\section{Labour market integration of migrant women: Good practices}

In Germany, there are two notable projects that focus on integrating migrant women into the labour market. First, the programme "Stark im Beruf" (strong at work) pushes for better labour market opportunities for mothers with a migration background (Stark im Beruf, n.d.). Secondly, the project "Starke Unternehmerinnen für starke Frauen: Eine Initiative für geflüchtete Frauen" (Strong entrepreneurs for strong women: An initiative for refugee women) offers refugee women support to integrate in the German labour market through "vocational and linguistic introductory coaching, support in the vocational orientation and development process, practical testing through a company internship, and individual support from a mentor" (GIZ, 2018, translated by the authors).

Similarly, Malta's Migrant Women Association aims to enable migrant women to integrate in the society of their host country. They do so by supporting women when they first arrive in their host country, offering professional or personal advice, and participating in joint projects and initiatives with other NGOs and organisations (Migrant Women Association Malta, n.d.).

Finally, She Matters Recruitment is an enterprise that aims at recruiting female migrants to work in the Netherlands. They specialise in engineering, architecture, business services and IT professionals. The company offers migrant women a programme in which they become familiar with things such as the Dutch business culture, intercultural communication, interview skills and more, and works to place them in employment once they have finished the programme (She Matters, n.d.).

\section{Asia and the Pacific}

According to the ILO (n.d.), labour migration is the most important reason for mobility in the Asia-Pacific region. The ILO states that 'labour migration occurs primarily under temporary migration regimes and for elementary occupations and medium-skilled work'. However, the region is also responsible for a large share of highly skilled migrants (mainly from China, India, and the Philippines). Oftentimes, migrants from Asia and the Pacific migrate to the Arab States (mostly South-East and South Asia) or to Australia and New Zealand (mostly seasonal workers).

When looking at Europe, the OECD (2016) states migration from Asia has been "a major component of overall migration to OECD countries over the past 10 years" (p.5). Since 2006, as many as 1.5 million Asian citizens migrate from their country of origin to an OECD country each year. In the report's top 15 OECD destination countries for Asian citizens (based on 2013 data from the OECD International Migration Database), the Netherlands ranks at number 12 with 17,000 migrants from the region. Asian migrants in the Netherlands are primarily from the People's Republic of China (28\%), India (26\%), Indonesia (8\%) and Japan (8\%). Finally, the report concludes that OECD countries attract many Asian students, many of whom stay in these countries, and are usually well-educated (OECD, 2016). 
In total, $15.0 \%$ of all migrant workers in the Netherlands come from North or South America, disregarding their educational/ skill level. According to a report by ECLAC and ILO (2017), the annual number of migrants from Latin America to Europe climbed from 5.6\% to $8 \%$ between 1990 and 2000. However, when many countries in Latin America had improved economic conditions and labour markets in the 2000s, the direction of migration flows reversed, and the number of migrants within Latin America grew with "an annual rate of $2.3 \%$ during that decade" (ECLAC \& ILO, 2017, p. 13). The report concludes that intraregional migration in Latin America has become more important, while migration to the United States and Europe has slowed down.

Khoudja (2018) finds that, on average, Antillean and Surinamese migrants in the Netherlands have higher educational levels and work in higher skilled jobs than Moroccan and Turkish migrants. However, they have lower levels of education and work in lower skilled jobs than the Dutch majority.

The literature review did not identify any other sources on the supply of migrants from Latin America and the Caribbean. Additionally, no sources on possible supply from North America could be identified either.

Migrant workers in the Dutch healthcare sector

According to a recent report on asylum migrants working in healthcare by the ACVZ (2021), the share of healthcare workers with a migration background in $\mathbf{2 0 1 9}$ was relatively low at $16 \%$. It is important to note that whenever the report mentions people with a migration background, it includes second generation migrants and people with one parent who was born outside the Netherlands. Table 13 shows the share of healthcare workers with a migration background per sub-sector in the healthcare industry. The data do not show any differences in educational level. The report also mentions that only $17.1 \%$ of doctors and $6.2 \%$ of nurses in the Netherlands were not born in the country (ACVZ, 2021). CBS data shows that $9 \%$ of all migrant workers were employed in the sector 'human health and social work activities' in 2017, but does not allow for a more detailed breakdown by occupation or educational or skill level (CBS, 2019a). 
Table 13: Share of employees with a migration background per healthcare sub-sector, 20152016

\begin{tabular}{|l|r|}
\hline Sub-sector in healthcare & Migration background \\
\hline Social work & $25 \%$ \\
\hline Youth care & $20 \%$ \\
\hline University medical centres & $20 \%$ \\
\hline Other healthcare & $19 \%$ \\
\hline Nursing, care and home care & $17 \%$ \\
\hline Mental healthcare & $16 \%$ \\
\hline General practitioners and healthcare centres & $15 \%$ \\
\hline Hospitals and other urgent care & $14 \%$ \\
\hline Disability care & $11 \%$ \\
\hline
\end{tabular}

Source: ACVZ (2021) based on OECD data

Refugees and asylum seekers

Syrian refugees in Europe tend to be more educated compared to Syrian refugees living in African or Middle Eastern countries and could also help to fill skills shortages at the upper secondary vocational level of the Dutch labour market (Oomes et al, 2019). However, a recent report by the ACVZ (2021) shows that even though there are large shortages in the Dutch healthcare sector, the Netherlands does not seem to employ many healthcare workers with a migration background. Even during the ongoing COVID-19 crisis, asylum seekers barely get the chance to work in healthcare in the Netherlands. The reason for this is that there are many restrictive migration laws that prevent asylum seekers from working, as well as the fact that their diplomas are not recognised very often (ACVZ, 2021).

\subsection{Why do the Dutch demand and foreign supply not match?}

The literature review has identified several factors that can make it difficult to match the Dutch demand with foreign supply, both from EEA+ countries and beyond. These can be divided into four groups:

- Structural barriers to migration (Dittrich \& Spath, 2016);

- Underutilisation of human capital (I.e.underemployment and misallocation (Het Kenniscentrum Arbeidsmigranten, 2021; Khoudja, 2018; Galgóczi, Leschke \& Watt, 2016) and problems with the recognition of qualifications including healthcare qualifications comparable to mbo4 level (CBGV, 2019);

- Unfavourable migration policies;

- Cultural, social and language barriers (Dittrich \& Spath, 2016; ACVZ, 2019; Dubow, Roeder, Marchand \& Siegel, 2019). 
While information on medium-skilled migration in the three focus sectors is scarce, we assume that the identified barriers equally apply to migrant groups of different education levels. Table 14 below lists several barriers to matching the Dutch demand and foreign supply. Most barriers concern intra-EEA+ migration of both EEA+ nationals and TCNs as well as migration of TCNs coming from outside EEA+ countries.

Table 14: Barriers to matching Dutch demand and foreign supply

\begin{tabular}{|c|c|}
\hline \multirow{5}{*}{ Structural } & Limited portability of pensions and social security \\
\hline & Lack of a structural European employment agency (uptake of EURES is limited in the entire EU) \\
\hline & Difficulties navigating the labour market \\
\hline & Lack of housing opportunities/expensive housing \\
\hline & Difficulties navigating the tax and social security systems \\
\hline \multirow{4}{*}{$\begin{array}{l}\text { Under- } \\
\text { utilisation }\end{array}$} & Recognition of foreign qualifications \\
\hline & Many migrant women do not work \\
\hline & Many migrants work below their educational level (underemployment) \\
\hline & Underutilisation of refugees and asylum seekers in the Netherlands \\
\hline \multirow[t]{4}{*}{ Policies } & Restrictive migration policies for medium-skilled workers \\
\hline & Limited free movement for non-EEA+ citizens \\
\hline & Recognition of qualifications \\
\hline & Absence of training or retraining facilities \\
\hline \multirow{3}{*}{$\begin{array}{l}\text { Cultural, } \\
\text { social and } \\
\text { language }\end{array}$} & Cultural barriers \\
\hline & Language barriers \\
\hline & Barriers to the creation of social networks \\
\hline
\end{tabular}


Sub-question 3: Is there a sufficient priority supply for these workers in the EEA and/or outside the EEA? If so, which supply and where; why do the Dutch demand and the foreign supply not match?

Answer:

\section{Priority supply}

- Skills shortages requiring personal intervention (e.g. healthcare related) as well as technical (STEM: scientific, technological, engineering or mathematical expertise) skills shortages are widespread and severe in the EEA+ countries. Health professions figure more prominently than in previous years; nurses even rank first among occupations with a shortage.

- Although the evidence is scarce, there seems to be hardly any oversupply in the EEA+ countries for the shortage occupations in the Netherlands, including those related to the three focus sectors, it is probably very difficult to recruit from the priority supply. We can conclude that it may be necessary to attract workers from third countries to fill the vacancies for these occupations.

\section{Relevance of supply from TCNs}

- Due to the aging population in the EEA+ countries, the supply of potential workers should be sought for outside these areas.

- There is a potential supply in Africa, but this is a relatively 'short-term' solution.

- Facilitating more options for the free movement of current TCNs in EEA+ countries could have a positive impact on their labour demand and supply.

- Strengthening the labour market position of migrant women may also increase supply.

\section{Limitations to matching Dutch demand and foreign supply}

- Within the EEA+ countries, there is hardly any priority supply that matches demand in Dutch shortage occupations (see above).

- European and Dutch migration policies focus on the highly skilled, which is why migration of the medium-skilled is more difficult to realise, even if there is a supply outside the EEA+ countries and even if people are willing to migrate.

- Limited transferability of foreign degrees and qualifications may contribute to underemployment of many migrants in the Netherlands. 


\section{Migration as a solution to address shortages in the middle segment of the Dutch labour market}

This section looks at existing European and Dutch migration policy tools that can play a role in bringing the Dutch demand and foreign supply together. It discusses opportunities and limitations of these instruments and the (im)possibilities for labour migration. In doing so, it will distinguish between two groups of migrants: 1) nationals from EEA+ countries, and 2) TCNs already residing inside as well as outside EEA+ countries. Again, the existing literature hardly covers medium-skilled migration in general and information on the three focus sectors specifically is very difficult to find. This section furthermore discusses the role of the assessment of foreign qualifications as this is often a prerequisite to fully benefit from medium-skilled labour migration. Finally, this section provides insights into what can be learnt from existing instruments in other countries, especially Germany. The questions related to this section refer to sub-question 4 of the introductory section of this report: Which instruments can play a role in bringing the Dutch demand and the foreign supply together? Where do the opportunities and limitations lie in this respect / possibilities and impossibilities for labour migration policy?

\subsection{European Union Law on Migration ${ }^{23}$}

\section{EU Directives on the entry of migrants}

To understand Dutch migration policy, EU law is vital (Kroes \& van Oort, 2020). The EU has the competence to define "the rights of [TCNSs] residing legally in a Member State, including the conditions governing freedom of movement and of residence in other Member States" (Art. 79(2)(b) TFEU). However, this does not "affect the right of Member States to determine volumes of admission of [TCNs] coming from third countries to their territory in order to seek work" (Art. 79(5) TFEU).

Nationals from EEA+ countries enjoy the right to free movement. Hence, there are in principle no legal barriers for medium-skilled workers to migrate within the EEA+ countries. The matter is more complicated for TCNs already residing in EEA+ countries and those coming from third countries. Table 15 below provides an overview of the seven Directives constituting the current EU legal migration acquis. Besides these, Member States can introduce more favourable rules and parallel national legislation ${ }^{24}$ (De Lange \& Groenendijk, 2021; Goldner Lang, 2018). Medium-skilled migration is not covered by any of these Directives specifically (De Lange \& Groenendijk, 2021). This is due to EU migration policy being geared towards attracting high-skilled, 'desirable' TCNs and limiting the entry of other groups of migrants, such as lowand medium-skilled migrants (Goldner Lang, 2018).

23 The agreement signed by the EEA+ countries enabling them to participate in the EU Internal Market covers "the free movement of goods, services, capital and persons, as well as competition and state aid rules and certain areas of cooperation such as consumer protection, environment, public health and education" (EFTA, n.d.). For this reason, EU law usually also applies to EEA+ countries. See also: https://eealaw.efta.int

24 The Dutch migration scheme for knowledge workers (kennismigranten) is an example of a parallel scheme to the EU Blue Card Directive. This has as a result that the Blue Card Directive is hardly used for highly skilled migration to the Netherlands, as the conditions of the knowledge workers scheme is more favourable. 
Table 15: EU Directives on the entry of migrants

\begin{tabular}{|l|l|l|}
\hline Directive & $\begin{array}{l}\text { Adopted } \\
\text { in }\end{array}$ & Brief description \\
\hline $\begin{array}{l}\text { Family Reunification } \\
\text { Directive 2003/86/EC }\end{array}$ & 2003 & $\begin{array}{l}\text { Sets rules for family reunification of non-EU nationals } \\
\text { and gives them equal access to the labour market } \\
\text { (De Lange et al., 2019) }\end{array}$ \\
\hline $\begin{array}{l}\text { Long- } \\
\text { Term Residents Directive } \\
2003 / 109 / E C\end{array}$ & 2003 & $\begin{array}{l}\text { "Sets criteria for obtaining a residence permit after } \\
\text { five years of lawful residence" (De Lange et al., 2019, } \\
\text { p. 4). Also includes rules for intra-EU mobility of these } \\
\text { residents. }\end{array}$ \\
\hline $\begin{array}{l}\text { Students and } \\
\text { Researchers Directive } \\
2016 / 801\end{array}$ & 2016 & $\begin{array}{l}\text { Researchers can work as teachers as long as their } \\
\text { main occupation is research. Students have to be } \\
\text { able to work 15 hours a week. }\end{array}$ \\
\hline $\begin{array}{l}\text { Blue Card Directive } \\
\text { Single Permit Directive }\end{array}$ & 2009 & $\begin{array}{l}\text { Admission of highly qualified workers } \\
\text { "It facilitates the procedure for TCNs to work and } \\
\text { reside in a member state through a 'single permit', } \\
\text { which is a combined work and residence permit. The } \\
\text { second main objective is to ensure equal treatment } \\
\text { between working TCNs [...] and member state } \\
\text { nationals" (De Lange \& Groenendijk, 2021, p.14). }\end{array}$ \\
\hline $\begin{array}{l}\text { Seasonal Workers } \\
\text { Directive 2014/36/EU }\end{array}$ & 2014 & $\begin{array}{l}\text { Entry conditions for temporary workers who migrate } \\
\text { for seasonal jobs }\end{array}$ \\
\hline $\begin{array}{l}\text { Intra-company } \\
\text { transferees 2014/66/EU }\end{array}$ & 2014 & $\begin{array}{l}\text { "Regulates admission in the event of intra-group } \\
\text { transfers of managers, specialists, or interns" (De } \\
\text { Lange et al, 2019, p. 5) }\end{array}$ \\
\hline
\end{tabular}

De Lange and Groenendijk (2021) discuss the flaws of the current EU legislation on migration and critically discuss the 2020 New Pact on Migration and Asylum in light of these. In particular, they criticise the limitations of intra-EEA+ migration of TCNs already residing in one of the EU Member States. For the purpose of this report, the Directives regarding Long-Term Residents (LTR) and Single Permits are especially relevant. The LTR Directive aims to align the rights of TCNs to those of EU nationals, including the right to free movement between the Member States. At the same time, the Directive allows for parallel national regulations, which are more frequently used and do not include the right for TCNs to move to another EEA+ country. In $2019,70 \%$ of long-term residents from third countries had acquired this status through a parallel national scheme. In Germany and Belgium, even 97\% have acquired longterm residency through national schemes instead of the EU Directives (De Lange \& Groenendijk, 2021). This suggests that the restricted rights to long-term residency can be a barrier to intra-EEA+ migration of TCNs and therefore impede filling skills shortages in the middle segment of the Dutch labour market. This is especially worrying because the first step for Dutch employers to recruit internationally is often to recruit workers residing in Belgium and (to a lesser extent) Germany (Reinold, forthcoming). Dello lacono et al. (2021) also confirm that most intra-EEA+ migration of TCNs occurs between neighbouring countries. The New Pact on Migration and Asylum aims to strengthen the rights of long-term residents from third countries, including the right to live and work in other EEA+ countries (De Lange \& 
Groenendijk, 2021). De Lange and Groenendijk (2021) welcome an amendment of the LTR Directive since "allowing TCNs with several years of lawful residence in a member state to respond to the demand for workers elsewhere in the EEA+ would be advantageous for the member states concerned and TCN workers alike" (p.20). It could reduce unemployment within the EEA+ countries and reduce the need to recruit individuals from outside EEA+ countries. This applies to low-, medium-, as well as high-skilled workers. De Lange and Groenendijk (2021) recommend that after lawfully residing in one Member State for three years, TCNs should be allowed to migrate to a second Member State for employment, based on their residence permit from the first Member State. After expiration of the permit, they should be allowed to choose if they would like to reside in the first or second member state. In the case of the former, the time spent elsewhere should not be discounted from the time migrants have to spend in the first Member State to be able to naturalise.

Furthermore, the Single Permit Directive is relevant in the context of this report, although it is very rarely issued in the Netherlands and the issuance of the temporary residence permit (mvv) falls outside the scope of the single permit (De Lange \& Groenendijk, 2021; ACVZ, 2019). The Directive provides "a single application procedure as well as a common set of rights for TCN workers legally residing in a Member State" (Goldner Lang, 2018, p. 9). It does not give TCNs the right to access the labour market, but it allows the host Member State's law to determine the access of TCNs to its labour market. At the moment, the Directive does not explicitly cover medium-skilled migrants. The New Pact on Migration and Asylum aims to change this in response to expected skills shortages in the middle segment of the labour market including in manufacturing, construction and healthcare (De Lange \& Groenendijk, 2021). This could also be realised through the introduction of a 'light' Blue Card targeting medium-skilled TCNs (De Lange \& Groenendijk, 2021).

Changes in the EU landscape of migration policy could also influence Dutch migration policies, even though at the moment the Netherlands are more known for their "national practice to deflect from the application of EU migration law and to prioritise national migration schemes" (De Lange \& Groenendijk, 2021, pp.14f.).

\section{Free movement of services: the intra-EU posting of (TCN) workers}

The literature review did not yield much information about the posting of workers (from third countries) to the Netherlands. Since we know from conversations with experts and practitioners that the posting of workers can be an issue, we conducted an additional search on the matter to gather more information. Again, the search (conducted in English and Dutch) did not lead to many results. The identified literature mainly discusses the general legal framework, advantages and disadvantages of posted work (Arnholtz \& Andersen, 2018; Cremers, 2016; Kall et al., 2020; Mussche \& Lens, 2019; Novitz \& Andrijasevic, 2020). More specific information on the trends and dynamics of posted work to the Netherlands is scarce and we could not identify any literature that covers the posting of TCNs working in the three focus sectors. 
Posted workers officially reside and work in one EEA+ country, but are sent to a second EEA+ country to provide a service for a temporary period of time. This can include the hiring out through a temporary work agency (uitzendbureau). Posting is based on the EEA's free movement of services and defined in Directive 96/71/EC concerning the posting of workers. In 2014, Directive 2014/67/UE on the enforcement of the Posting of Workers Directive was introduced to address fraudulent practices and the exploitation of posted workers. It is important to emphasise that posting "was meant neither to provide a regulatory framework for cross-border temporary work agencies nor to fuel the creation of a new type of recruitment" (Cremers, 2016, p.156). Rather, it was established to provide a legal framework governing the conditions of (sub-)contractors providing temporary services in another EU Member State. Nevertheless, the posting of workers is often treated as a cheap way of recruiting labour from abroad (Cremers, 2016).

Common assumptions hold that only EEA+ nationals can become posted and that it concerns mostly Eastern European workers being posted to Western EU Member States. The phenomenon is, however, more diverse and a large share of posted workers also come from Western EU Member States. TCNs with a valid work and residence permit in one EEA+ country can also be posted across the EEA+. With the 1994 Vander Elst case and subsequent case law, the European Court of Justice "essentially created a parallel system of mobility for TCN labour migrants for whom the gates of Europe would otherwise remain locked to a great extent" (Lens, Mussche \& Marx, 2021, p.5). The posting of TCN workers does not involve any migration requirements on parts of the country to which the worker is posted. Furthermore, the posted workers remain subject to the social security system of the country from which they are posted (De Wispelaere, De Smedt \& Pacolet, 2020). The Portable Document (PD) A1 proves that a posted worker already pays social security contributions in another EU Member State and therefore does not have to pay again in the country he or she is posted to.

The analysis of these documents can provide indications of the magnitude, characteristics and impact of intra-EEA+ posting. In $2018,0.8 \%$ of total EEA+ employment was carried out by individuals with a PD A1 issued. Since 2011 an upward trend regarding the number of PD A1 issued was observed. It can be distinguished between three groups: "1) employed persons who are employed by an employer which normally carries out its activities in a Member State and who are posted by that employer to another Member State to perform work on its behalf (Article 12(1) of the Basic Regulation [Regulation (EC) No 883/2004]), 2) persons who normally pursue an activity as a self-employed person in a Member State who go to pursue a similar activity in another Member State (Article 12(2) of the Basic Regulation); and 3) persons who pursue an activity as an employed/self-employed person in two or more Member States (Article 13 of the Basic Regulation)" (De Wispelaere et al, 2020, p. 8). Most PDs A1 were issued under Article 12 and of these $36 \%$ were issued in Poland and Germany and in the construction sector. Services are mostly provided in Germany, France, Belgium, the Netherlands, Austria and Switzerland. Poland is also the most important country issuing PDs A1 according to Article 13 of the Basic Regulation (see figure below), which mostly concerns truck drivers (De Wispelaere et al, 2020). 
Figure 3: Total number of PDs A1 issued per EEA+ country, 2018

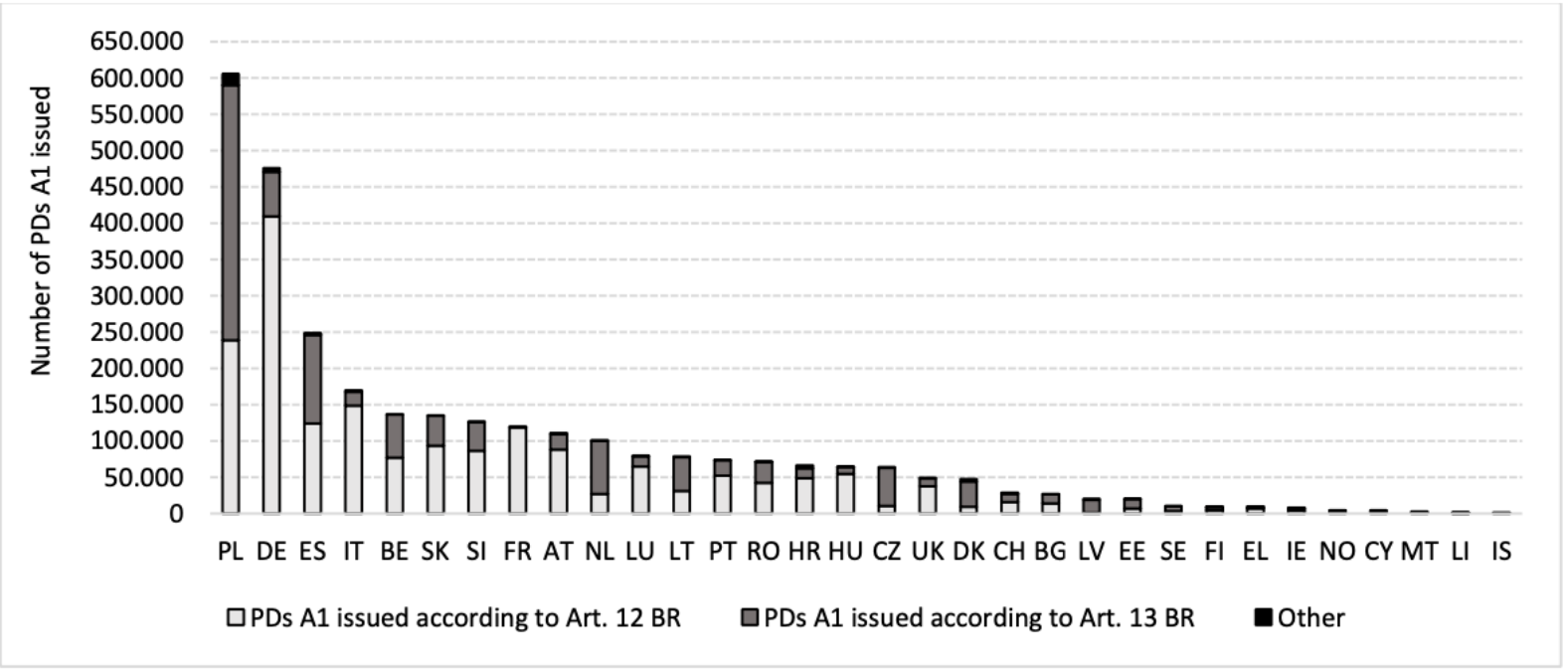

Source Administrative data PD A1 Questionnaire 2019

Source: De Wispelaere et al. (2020), p.10

Since migration policies of many EEA+ countries favour the highly skilled and aim to restrict the migration of less skilled groups, the posting of TCN workers is described as a "hole in the wall of fortress Europe" and could potentially become a "mobility channel on equal footing with 'traditional' TCN labour migration"(Lens et al, 2021, p.2). Lens et al (2021) call the intra-EEA+ posting of TCN labour migrants "a new and understudied phenomenon" (p.2) and claim that their study is the first quantitative assessment of this new phenomenon. Analysing online registrations of posted workers to Belgium between 2008 and 2019, Lens et al (2021) conclude that the intra-EEA+ posting of TCN workers is on the increase and that it mainly concerns low- and medium-skilled workers. Between 2008 and 2019 the total number of posted workers more than doubled. The most important posting sector in Belgium is Construction (31\% of all posted workers in 2019), logistics and metal and pipe fitting (10\% each), and maintenance of electrical machinery (5\%). While posted TCNs with around 200 different citizenships were identified, the top 6 of all posted TCNs between 2008 and 2019 in Belgium were citizens of Ukraine, Bosnia and Herzegovina, Turkey, Brazil, Kosovo and Serbia. Most Ukrainians were posted from Poland, workers from the Western Balkans from Slovenia, Turkish nationals from Germany or the Netherlands, and Brazilians from Portugal (Lens et al, 2021). The posting of workers comes with several advantages and disadvantages.

\section{Advantages of posting workers}

- Posting opens new ways of legal migration (Mussche \& Lens, 2019), which

- can help address skills and labour shortages more efficiently;

- can be more feasible than traditional migration channels for TCNs (Danaj et al, 2020); and

- can increase mobility rights of TCN workers, whose rights to intra-EU migration are otherwise rather restricted (de Lange \& Della Torre, 2017; Mussche \& Lens, 2019).

- The duration of a posting is limited to 12 (or sometimes 18) months, after which the workers are "entitled to 'all the applicable terms and conditions of employment' on a free 
movement basis and not just the core protections in Article 3 (of the Posted Worker Directive)" (Novitz \& Andrijasevic, 2020, p. 13).

\section{Disadvantages of posting workers}

- Posted workers are

$\circ$ at higher risk of exploitation and the risk is the highest for posted intraEU TCN workers (Lens et al, 2021, p.2);

$\circ$ in a legally more uncertain situation in terms of employment and migration status (Novitz \& Andrijasevic, 2020);

- dependent on their employers;

- more easily trapped in irregular employment without access to social security and/or healthcare (Kall et al, 2020);

- often not aware of their rights or scared to stand in for them (Kall et al., 2020; Cillo, 2020); this can be exacerbated if in sending countries there is limited trust in trade unions, which are consequently not reached out to for support (Kall et al, 2020).

- Trade unions cannot "negotiate wages as traditionally done" (Arnholtz \& Anderson, 2018, p. 397).

- Employers can (ab)use posting to save labour costs (e.g. wage dumping, poor working conditions, longer (unpaid) working hours, unreasonable deductions for accommodation and transport, etc.) (Lens et al, 2021; Arnholtz \& Andersen, 2018; Novitz \& Andrijasevic, 2020; Cremers, 2018, p. 4;), which "causes pressures on local labour markets" (Lens et al, 2021, p.4).

- Fraudulent practices are difficult to detect and prosecute due to fragmented regulations and blurred legal boundaries (Cremers \& Dekker, 2018).

\section{Revisions to the Posted Workers Directive}

The European Commission's proposal to revise the PWD aimed at "ensuring the smooth functioning of the single market and stopping unfair competition on wage costs and working conditions" (Houwerzijl \& Schrauwen, 2018, p. 99). Revisions were adopted in 2018 and implemented in 2020.

Houwerzijl \& Schrauwen (2018) state that the revision of the Directive, in combination with the Posting of Workers Enforcement Directive, could have a slight positive impact on the rights of posted workers. Novitz \& Andrijasvic (2020) conclude that the revision includes positive changes: steps have been taken to "alter the duration of posting (12 to 18 months, afterwards workers are entitled to all terms and conditions of employment), regulate the extensive involvement of temporary work agencies (TWAs) and respond to issues relating to accommodation and other terms of hire" (p. 1338). States also have the option to implement new regulations aimed at equal treatment. However, Novitz and Andrijasevic (2020) criticize that more needs to be done to address issues such as the lack of trade union access and difficulties concerning the way posted workers are hired, since employment and immigration status can sometimes be uncertain for the workers. 


\subsection{Available Dutch migration policy tools}

\section{Relevant migration schemes for medium-skilled workers from third countries}

Dutch migration policies, similar to those at the EU level, focus on attracting high-skilled migrants, who are perceived as more valuable for the economy than the low-or medium-skilled migrants (ACVZ, 2019). "The middle segment of the labour market is [...] not supported by a labour migration policy adapted to it" (ACVZ, 2019, p. 66; translation from Dutch by the authors).

EEA+ nationals have the right to free movement and can therefore move to the Netherlands for employment without having to apply for a visa, work or residence permit. Migrating to the Netherlands from outside EEA+ countries is more complex. Labour migration from third countries is usually employer-led or demand-driven (De Lange et al, 2019), which means that the employer is responsible for applying for the migrant's visa, work and residence permit. To hire these TCNs, employers should report their vacancies to the UWV first to check that it is impossible to hire someone from the so-called 'priority supply' that lives in the Netherlands or in another EEA+ country. The Netherlands mainly focuses on the attraction and retention of highly skilled workers, but their policy is very restrictive when it comes to medium- and lowskilled workers (EMN, 2015). Currently, there is no scheme in place that is specifically designed for the medium-skilled. There is (limited) room for this group of migrants to migrate to the Netherlands through other schemes that are open to migrants with various skill levels. The most important channels open for medium-skilled migration to work in the focus sectors of this study are summarised in Table 16 below.

Table 16: Relevant migration schemes for medium-skilled workers from third countries in the focus sectors

\begin{tabular}{|l|l|l|l|}
\hline $\begin{array}{l}\text { Migration } \\
\text { scheme }\end{array}$ & Description & Conditions/ requirements & $\begin{array}{l}\text { Application } \\
\text { procedure }\end{array}$ \\
\hline $\begin{array}{l}\text { Regular labour } \\
\text { migration }\end{array}$ & $\begin{array}{l}\text { Migration for the } \\
\text { purpose of work, } \\
\text { excluding seasonal } \\
\text { labour or work } \\
\text { experience. }\end{array}$ & $\begin{array}{l}\text { 1.Employment contract with company in } \\
\text { NL (recognition as sponsor not } \\
\text { mandatory) } \\
2 . \text { Migrant worker must earn the } \\
\text { minimum wage }\end{array}$ & $\begin{array}{l}\text {-Employer-led: Single } \\
\text { Permit25, i.e. } \\
\text { combined residence } \\
\text { and work permit } \\
\text { (gvva }{ }^{26} \text { ) } \\
- \text { Costs for application: } \\
\text { EUR 320 }\end{array}$ \\
\hline $\begin{array}{l}\text { Intra-corporate } \\
\text { transfer (Directive } \\
2014 / 66 / E U)\end{array}$ & $\begin{array}{l}\text { Employee of a } \\
\text { company established } \\
\text { outside of the EEA+ } \\
\text { is transferred to a }\end{array}$ & $\begin{array}{l}\text { 1.Employee resides in a country } \\
\text { outside the EEA+/ within the EEA+ on } \\
\text { the basis of an intra-corporate transfer } \\
\text { at the time of application }\end{array}$ & $\begin{array}{l}\text {-Employer-led, } \\
\text { possibility for worker } \\
\text { to apply as well: } \\
\text { Single Permit (gvva) }\end{array}$ \\
\hline
\end{tabular}

25 "Directive 2011/98/EU of the European Parliament and of the Council of 13 December 2011 on a single application procedure for a single permit for third-country nationals to reside and work in the territory of a Member State and on a common set of rights for third-country workers legally residing in a Member State" https://eur-lex.europa.eu/legal-content/EN/ALL/?uri=CELEX\%3A32011L0098.

26 The gvva (gecombineerde vergunning voor verblijf en arbeid) is intended for a foreign employee that stays for 90 days or longer. This permit is applied for at the Immigration and Naturalisation Service (Immigratie- en Naturalisatiedienst, IND).

27 Additional costs apply for the migrant's family members and for collecting the required documents, having them translated, etc. 


\begin{tabular}{|c|c|c|c|}
\hline & $\begin{array}{l}\text { branch in the } \\
\text { Netherlands }\end{array}$ & $\begin{array}{l}\text { 2.Employee will work in NL as } \\
\text { manager, specialist or trainee } \\
\text { 3.Employee is transferred within the } \\
\text { same company } \\
\text { 4.Employee has been working for the } \\
\text { company for at least } 3 \text { months } \\
5 . \text { Employee has a valid work contract } \\
\text { with the company/an assignment letter } \\
\text { from the employer } \\
\text { 6. Employee has the right qualifications } \\
\& \text { experience } \\
\text { 7.If employee practises a regulated } \\
\text { profession (doctor, architect), they must } \\
\text { prove they are entitled to practise the } \\
\text { profession } \\
8 . T e r m s ~ \& \text { conditions of employment } \\
\text { comply with the law } \\
\text { 9.Salary is in line with the market } \\
\text { 10.Establishment in NL was not created } \\
\text { to make transfers to NL easier } \\
11 \text {.Employee has not been transferred } \\
\text { to NL in the } 6 \text { months preceding } \\
\text { application } \\
12 \text {.Employer must not have been fined } \\
\text { in the } 5 \text { years prior to application }\end{array}$ & $\begin{array}{l}\text {-Costs for application: } \\
\text { EUR } 320\end{array}$ \\
\hline $\begin{array}{l}\text { Intra-company } \\
\text { transfer (other } \\
\text { than Directive } \\
2014 / 66 / E U \text { ) }\end{array}$ & $\begin{array}{l}\text { Migration to work in } \\
\text { NL as a trainee, } \\
\text { company } \\
\text { representative or } \\
\text { specialist in an intra- } \\
\text { company transfer }\end{array}$ & $\begin{array}{l}\text { 1. The organisation of your employer is } \\
\text { entered in the commercial register of } \\
\text { the Chamber of Commerce (if required) }\end{array}$ & $\begin{array}{l}\text {-Employer-led: Single } \\
\text { Permit (gvva) } \\
\text {-Cost for application: } \\
\text { EUR } 320\end{array}$ \\
\hline $\begin{array}{l}\text { International } \\
\text { trade regulation }\end{array}$ & $\begin{array}{l}\text { Worker at a foreign } \\
\text { company moves to } \\
\mathrm{NL} \text { in the context of a } \\
\text { project/joint venture }\end{array}$ & $\begin{array}{l}\text { 1.Employee is temporarily working in } \\
\text { NL within the scope of a project in the } \\
\text { context of the International Trade } \\
\text { Regulation approved by the UWV } \\
\text { 2. Employer has notified the UWV that } \\
\text { an employee is coming to NL to work }\end{array}$ & $\begin{array}{l}\text {-Employee/company } \\
\text { applies for residence } \\
\text { permit (no work } \\
\text { permit (TWV) } \\
\text { necessary } \\
\text {-Costs for application: } \\
\text { EUR } 320\end{array}$ \\
\hline $\begin{array}{l}\text { Supply of goods } \\
\text { by a foreign } \\
\text { company }\end{array}$ & $\begin{array}{l}\text { Migration to work in } \\
\text { paid employment in } \\
\text { NL for the assembly } \\
\text { and repair of } \\
\text { equipment delivered } \\
\text { by foreign companies }\end{array}$ & $\begin{array}{l}\text { 1.Employee must earn a sufficient } \\
\text { income } \\
2 . \text { Organisation is entered in the } \\
\text { commercial register of the Chamber of } \\
\text { Commerce (if required) }\end{array}$ & $\begin{array}{l}\text {-Employee/employer } \\
\text { applies for Single } \\
\text { Permit (gvva) } \\
\text {-Costs for application: } \\
\text { EUR } 320\end{array}$ \\
\hline $\begin{array}{l}\text { Secondary or } \\
\text { vocational } \\
\text { education in the } \\
\text { Netherlands }\end{array}$ & $\begin{array}{l}\text { Migration to attend } \\
\text { secondary or } \\
\text { vocational education } \\
\text { in NL }\end{array}$ & $\begin{array}{l}\text { 1.NL is the most appropriate country for } \\
\text { education, permit is not granted if } \\
\text { similar education is available in the } \\
\text { country of origin. Additionally, meet at } \\
\text { least } 2 \text { of the following conditions: } \\
\text {-Applicant is a national Suriname, } \\
\text { Indonesia or South Africa } \\
\text { - The applicant has family ties with a } \\
\text { Dutch national or permanent resident } \\
\text {-Dutch language skills } \\
\text { 2.Education makes a positive } \\
\text { contribution to the development of } \\
\text { origin country, depending on the } \\
\text { development level \& study } \\
\text { 3.Provisional proof of registration at an } \\
\text { educational institution } \\
4 . \text { Independent sufficient \& sustainable } \\
\text { income }\end{array}$ & $\begin{array}{l}\text {-Student applies for a } \\
\text { residence permit, } \\
\text { educational institution } \\
\text { provides list of } \\
\text { necessary documents } \\
\text {-Costs for application: } \\
\text { EUR } 192\end{array}$ \\
\hline
\end{tabular}

28 The employer applies for a work permit (tewerkstellingsvergunning, TWV) with UWV, which examines among other things if there is no employee with the Dutch, EU/EEA or Swiss nationality that is qualified for the job. 


\section{Circular migration schemes}

Circular migration is a form of temporary migration in which an individual repeatedly moves back and forth between two or more countries (IOM, 2019), usually for the purpose of labour (Rahim, Rayp \& Ruyssen, 2021; IOM, 2019). It is associated with benefits for migrants themselves, as well as their host and home countries, although these are subject to debate. Among other things, circular migration schemes are seen as a flexible way to mitigate skills shortages and curb irregular migration (Rahim et al, 2021, p.6). One can distinguish between spontaneously occurring de facto circular migration and managed government-led circular migration schemes. The interest in the latter as an alternative to long-term immigration policy is rising especially where anti-immigrant rhetoric is a concern (Rahim et al, 2021). Rahim et al (2021) reviewed selected circular migration schemes including for the medium-skilled. They find that circular migration schemes more often target less educated migrants and focus especially on sectors that are seasonal in nature (e.g. agriculture, tourism, construction). They are often regulated through bilateral agreements between the migrants' home and host countries, which define the employment conditions (e.g. sector, duration, etc.).

\section{Example 1: Blue Birds Circular Migration Pilot Project}

This project was implemented between 2010 and 2011 in the Netherlands as a tool for development cooperation and to address shortages in the Dutch labour market through circular migration from third countries, especially Indonesia and South Africa. Based on a sector analysis, the metal industry, food industry, agribusiness and logistics were chosen as focus sectors with significant labour shortages. The target group were migrants with vocational training. For their recruitment, no labour market test was necessary and they could stay in the Netherlands for up to two years. Rahim et al (2021) identified this programme as a "notable example of an unsuccessful scheme caused by having too many objectives and the lack of specific focus" (p.11f) in terms of objectives, countries, and sectors. The involvement of various stakeholders made implementation difficult and employers were unwilling to get involved due to lack of clarity and flexibility. After 15 months, only eight of the envisaged 160 participants were recruited (Rahim et al, 2021; Siegel \& van der Vorst, 2012). For a full evaluation of the project as well as recommendations for future circular migration projects, see Siegel and van der Vorst (2012). The report also includes a summary of the history of circular migration in the Netherlands and examples of circular migration schemes from other countries.

\section{Example 2: MATCH}

The project MATCH implemented by the International Organization for Migration (IOM) between 2020 and 2023 focuses on addressing labour market shortages in Italy, Belgium, Luxembourg, and the Netherlands through circular migration. The project facilitates approximately 210 migrants from Nigeria and Senegal to work for one to two years in sectors where labour market shortages were established (e.g. ICT, technology, digitalisation and healthcare). Migrants who participate in MATCH can upscale their skills, increase their employability and contribute to knowledge transfer and capacity building in their country of origin. To recruit migrants, employers can send vacancies to $\mathrm{MATCH}$, which then starts a selection process in Nigeria and Senegal. IOM and local partners conduct a pre-screening of candidates to ensure that they meet the employer's requirements. The companies then receive a shortlist of the best candidates and can finalise the recruitment process themselves. Through this targeted support recruiting from third countries also becomes an option for employers with less resources and experience with hiring migrants (e.g. SMEs) (Hooper, 2021). In the Netherlands, IOM cooperates with the Netherlands-Africa Business Council to implement MATCH (IOM, 2021; IOM, 2020). 
The many different schemes show how fragmented the Dutch migration policy landscape is. They follow stricter rules and the ACVZ (2019) criticises that they make it difficult to respond to actual needs for labour. Sectoral policies, which could be a solution to filling labour market shortages in certain sectors, are less prominent in the Netherlands. One exception is the 'regulation for asian catering' (regeling aziatische horeca), which facilitates the migration of Asian chefs to the Netherlands (ACVZ, 2019; De Lange et al, 2019). At the time of writing this report, there are discussions going on to adapt the regulation due to serious abuse such as labour exploitation, fraud, debt bondage, human smuggling and trafficking (Koolmees, 2021). This points to the importance of designing sectoral migration policies in a way that limits abusive and fraudulent practices.

\section{Opportunities and limitations of available Dutch legal instruments}

Well-managed migration schemes can contribute to filling shortages of qualified personnel at the upper secondary vocational level of the Dutch labour market, including in the three focus sectors (OECD, 2018). Migration can rejuvenate the Dutch workforce (Het Kenniscentrum Arbeidsmigranten, 2021) and increase the Netherlands' competitiveness. Despite these benefits, migration cannot be the only solution to mitigating skills shortages.

In contrast to, for example, Dutch migration policy and schemes for the highly skilled ${ }^{29}$, there are no specific channels for medium-skilled migration. In addition, lengthy procedures make it difficult to hire someone from abroad on short notice, which can discourage employers from recruiting individuals from abroad altogether (ACVZ, 2019). For example, it can take up to 10 months for a hired TCN to start their job with a Dutch firm because this is how long it can take to obtain their temporary residence permit (mvv) and single permit (ACVZ, 2019). The length of the application procedure varies depending on whether employers are recognised as sponsors or not, which is not mandatory in the case of regular labour migration.

As relevant migration schemes are mostly employer-led, the extent to which Dutch demand can be met by foreign supply depends largely on the initiative of employers. If they are not familiar with the system, it is possible that they shy away from hiring internationally and try to find alternative solutions for filling the gaps in their companies, which may be less ideal. In fact, Dutch employers seem to rarely use migration as a means to address skills shortages (ACVZ, 2019). Dutch SMEs seem to regard labour migration as a last resort and if they do recruit labour migrants, they prefer workers from neighbouring countries and migrants already residing in the Netherlands because of less administrative hurdles (Reinold, forthcoming). The situation is similar in Germany, where firms, including SMEs, prefer alternative solutions to meeting skills shortages (Mayer \& Clemens, 2021). This is because many are worried that recruiting migrants could involve high costs and uncertainties, for example related to communication on the work floor and the recognition of qualifications (Mayer \& Clemens, 2021; Barslund \& Busse, 2016). Mayer and Clemens (2021) therefore recommend investing in more research to better understand why recruitment from abroad

29 Highly skilled migrants from third countries can move to the Netherlands as Knowledge migrant (Kennismigrant), as an EU Blue Card holder, as Researcher, as Intra-corporate transferee, via the International Trade Regulation, as a Student, and for an orientation year (zoekjaar). 
plays a minor role in addressing skills shortages at companies, at least in the case of Germany. This could form a basis to provide more targeted support for companies or to increase cooperation between countries of origin and destination to limit uncertainties. EU-funded talent and mobility partnerships and other projects (concerning for example vocational training courses), which provide targeted support for employers in recruiting from third countries can also contribute to reducing remaining hurdles (Hooper, 2021).

\subsection{The role of the assessment of foreign qualification, knowledge and skills}

\section{Assessment of foreign qualifications}

The assessment of foreign qualifications or skills and competences is relevant when looking at labour market access for medium-skilled workers for two reasons: firstly, in the case of regulated occupations, professional recognition is mandatory for gaining access to the occupation. Accruing a work permit for a regulated occupation also requires incoming workers to meet the professional recognition requirements applicable to the profession. To be issued a work permit for a regulated occupation, incoming workers must also meet the professional recognition requirements applicable to the profession. Secondly, documenting knowledge and competences can be important for employers to understand who would be suitable for their positions.

In the Netherlands, three types of recognition are of relevance: firstly, there is professional recognition for gaining access to regulated occupations. This is especially relevant in the healthcare sector, as will be discussed below. Next, credential evaluation (diplomawaardering) procedures are relevant for non regulated occupations in the middle segment of the Dutch labour market. Lastly, procedures for the validation of prior learning (VPL) are also important for migrants, whether for use in the labour market or for education purposes.

\section{Professional recognition}

A first type of assessment, professional recognition, i.e. recognition to gain access to a profession is only relevant for regulated occupations. In the healthcare sector, regulatory requirements are especially important. When looking at qualifications at the mbo level-4, the following three degrees require a type of recognition before their holders are allowed to practice the relevant occupations: pharmaceutical assistant (mbo 4-level), mbo 4-level nurse ${ }^{30}$ and (personal) healthcare assistant (HCA, see also Section 3$)^{31}$. In what follows we describe the recognition requirements for each of these occupations and reflect on their role in the access of medium-skilled migrants to their occupations. What recognition procedures are required, depends on the qualification and the country where the original qualification was acquired. In Table 17 we describe these procedures for each specific occupation.

30 Mind that in the Netherlands a significant share of the nurses is educated at the bachelor-level, i.e. hbo.

31 (Personal) Healthcare assistant, HCA, or verzorgende ig (individuele gezondheidszorg) in Dutch, which is an education at the mbo 3-level (i.e. one level below mbo 4-level) 
Table 17: Diploma recognition procedures for medium-skilled healthcare occupations

\begin{tabular}{|c|c|c|}
\hline Degree & $\begin{array}{l}\text { Requirements for degrees from } \\
\text { EEA+ countries }\end{array}$ & $\begin{array}{l}\text { Requirements for degrees } \\
\text { from outside EEA+ }\end{array}$ \\
\hline $\begin{array}{l}\text { Pharmaceutical assistant } \\
\text { (mbo 4-level) }\end{array}$ & $\begin{array}{l}\text { - Recognition of professional } \\
\text { qualifications }\end{array}$ & $\begin{array}{l}\text { - Certificate of Competence } \\
\text { (incl. AKV-toets, } € 190 \text { ) }\end{array}$ \\
\hline Nurse (mbo 4-level) & $\begin{array}{l}\text { Direct enrolment in the BIG } \\
\text { register (automatic recognition) } \\
\text { (BIG registration, } € 85 \text { ) } \\
\text { - In case of a degree older than } 5 \\
\text { years: applying for BIG re- } \\
\text { registration also mandatory }\end{array}$ & $\begin{array}{l}\text { - Certificate of Competence } \\
\text { - BIG registration } \\
\text { (incl. AKV-toets, € 190; BI- } \\
\text { toets, €40; BIG registration, } \\
€ 85 \text { ) }\end{array}$ \\
\hline $\begin{array}{l}\text { (Personal) Healthcare } \\
\text { assistant, HCA (mbo 3- } \\
\text { level) }\end{array}$ & $\begin{array}{l}\text { - Recognition of professional } \\
\text { qualifications }\end{array}$ & $\begin{array}{l}\text { - Certificate of Competence } \\
\text { (incl. AKV-toets, } € 190 \text { ) }\end{array}$ \\
\hline
\end{tabular}

Source: https://advieswijzer.bigregister.nl/en

Each procedure has its own characteristics:

- The procedure for recognition of professional qualifications applies to those with a non-automatically recognised qualification obtained in a non-EEA+ country. The application has to be submitted to CIBG, an executive organisation of the Ministry of Health, Welfare and Sport. The procedure can take up to twelve weeks once all the necessary documents are submitted and can be extended by one month if necessary. The Commission for Foreign Healthcare Graduates (CBGV) will assess the application. If necessary, the CBGV will submit the application to Nuffic (Dutch Organisation for Internationalisation in Education) or the SBB (Foundation for Cooperation on Vocational Education) for advice. The CBGV will then advise on the application to the CIBG who will be formulating a decision on the recognition of professional qualifications. This decision can be positive, negative or require an adaptation internship or a proof of competence before granting the recognition. Lastly, nurses have to apply for BIG registration (see below) (CIBG, n.d.-d).

- The BIG registration procedure is a mandatory registration for a number of healthcare professionals, including nurses. It allows them to use their legally protected titles and practice the profession independently. Re-registration with $\mathrm{BIG}$ is mandatory for all healthcare professionals every five years (CIBG, n.d.-c, n.d.-a).

- The procedure for direct enrolment in the BIG register (automatic recognition) applies to holders of a nursing degree 'younger' than 5 years. If applicants fulfil the additional BIG requirements, including having a proof of Dutch language proficiency, they can directly apply for BIG registration. The holders of a nursing degree that is older than 5 years, must also directly fulfil the re-registration criteria for registering in the BIG register (CIBG, n.d.-c).

- The certificate of competence is a procedure that is applicable to healthcare professionals with a qualification obtained in a non-EEA+ country. After submitting the application to CIBG, Nuffic will carry out a check on the authenticity of the qualification and the overview of the subjects. All applicants for a certificate of competence need to 
take the general knowledge and skills test (Algemene Kennis- en Vaardighedentoets or AKV-toets, $€ 190]$, in which Dutch language proficiency is the most important part of the general knowledge test. Depending on the profession, additional tests may be required. Nurses also have to take a professional test (Beroepsinhoudelijke toetsing or Bl-toets, €400]. After taking and passing these tests, the Commission for Foreign Healthcare Graduates assesses the application. They decide if the application gets approved directly or if additional courses of work placements are in order. Next, the CIBG will formulate an intended decision on the certificate of competence. A positive result is sufficient for pharmaceutical assistants and (personal) healthcare assistants. Nurses have to additionally apply for BIG registration (€85) after a positive result to be allowed to practice their profession (CIBG, n.d.-b).

It appears that the number of people with a non-EEA+ qualification applying for recognition is relatively small in all three occupations. In 2019 there were 51 nurse applicants with a nonEEA+ qualification for the Professional test (BI test). Furthermore, in 2019, the Commission for Foreign Healthcare Graduates issued only 1 advice for a pharmaceutical assistant qualification and 14 for (personal) healthcare assistants. (CBGV, 2019).

A recent report by the ACVZ (2021) examined the access of asylum migrants to occupations in the healthcare sector. It finds that laws and regulations create obstacles for the recognition of foreign qualifications and competences. Getting the qualifications recognised in healthcare occupations can be quite a lengthy process, especially for holders of degrees from outside the EEA+ countries. As can be seen above, the procedure for this group is more involved and more expensive. The duration of the recognition procedure/getting access to the occupation depends on various aspects, but on average, for nurses, it takes about three years after submitting the application (ACVZ, 2021). The ACVZ makes two major recommendations for facilitating access to occupations in the healthcare sector for asylum migrants. Firstly, it recommends speeding up and simplifying the procedure for recognition of foreign healthcare degrees. Both regarding the various steps of the recognition procedure (including financially) as well as with regard to the guidance in the procedure. Secondly, it suggests that healthcare organisations could offer more to work or do internships under supervision (for example after completing an aptitude test). They could also make more use of VPL procedures. To some extent these suggestions could be relevant for other non-EEA+ migrants as well and potentially prove useful for addressing shortages in this sector.

Muller, Beckers and Pijpers (2017) identify two additional obstacles for TCNs to get their qualifications recognised in the healthcare sector. Firstly, the recognition procedures turn out to be complex and often poorly understood by TCNs, making identifying recognition options, pathways and alternatives challenging. Secondly, there is a high dropout rate in the process of both $\mathrm{AKV}$ and $\mathrm{BI}$ tests. At the root of this might be the language proficiency requirements and the high costs of the procedures.

In the energy transition sector, the main shortage occupations are 'Electricians and electronics mechanics' (Elektriciens en elektronicamonteurs) for which an 'Electrical and installation engineering education' at mbo level-4 (mbo 4 Elektro-en installatietechniek) is required. In the metal sector of industry, the main shortage occupations are (mechanical) 
engineers, with mbo level-4 Mechanical engineering and metalworking as educational background. For these sectors, there are no regulated occupations on mbo level-4 for which qualification recognition is mandatory (European Commission, n.d.).

\section{Evaluation of foreign credentials}

A second type of credential assessment, evaluation of foreign credentials (diplomawaardering), can be relevant for migrants who want to work in those unregulated occupations. Foreign credential evaluation can give a good indication of the value of a foreign diploma in the Netherlands and can be used both for finding fitting employment and finding a suitable study. The department of Credential Evaluation and Education Comparison (Afdeling Diplomawaardering en Onderwijsvergelijking) is responsible for diploma evaluation of foreign qualifications at VMBO and MBO level. Applications have to be submitted to the Credential Evaluation Information Center (Informatiecentrum Diplomawaardering, $I c D W)$ ) which is the joint digital contact point of SBB and Nuffic (Dutch organisation for internationalisation in education.) The IcDW handles the administrative processing of applications for credential evaluation. A credential evaluation procedure costs $€ 148.83$ and takes between four and six working weeks to be processed. Credential evaluation is an advice and no legal rights can be derived from it (IDW, n.d.a, n.d.b).

\section{Validation of prior learning (VPL)}

A last type of recognition is the so-called validation of prior learning (VPL, in Dutch Erkenning van Verworven Competenties, EVC). This policy instrument falls under the strategy of lifelong learning and is based on the Convenant ter stimulering van het erkennen van eerder verworven competenties als onderdeel van een leven lang leren. This procedure can be relevant when the recognition of formal competencies is not an option. VPL can be used for two routes:

- In the labour market route, prior learning outcomes of individuals are validated against sector or organisation standards. Various tools are used to map what knowledge and competences individuals possess, such as e-portfolio, experience profiles (ervaringsprofielen) and competence tests. The VPL results in an Experience Certificate (Ervaringscertificaat), attesting the tested knowledge and competences. The average price of the VPL procedure is between $€ 1,000$ and $€ 1,500$ and the procedure takes on average about three months. The National EVC Knowledge Center provides quality assurance for the labour market route (Duvekot, 2019; Nationaal Kenniscentrum EVC, n.d.).

- For the education route of VPL, applicants validate their formally/informally/nonformally acquired competences as a step to obtaining a formal qualification. The learning outcomes and competences of the applicant are tested against national qualification standards using tools such as intake-assessments, e-portfolios and competence tests. This process can also result in an Experience Certificate which can be part of the assessment of someone's learning outcomes. However, this certificate is not essential for obtaining exemptions or a partial/full qualification (Duvekot, 2019). 
The value of the VPL highly depends on employers and educational institutes endorsing and accepting the VPL certificates. In the healthcare sector, VLP is complicated because of the strong emphasis on formal degrees and qualifications (Muller et al., 2017). In their report, the ACVZ (2021) lists a number of practical examples of initiatives working towards facilitating VPL.

\subsection{What can be learnt from other countries?}

The current and forecasted labour market shortages in the Netherlands make it worthwhile to investigate what the Netherlands can learn from Germany to become more attractive for medium-skilled workers from other EEA+ countries as well as from third countries. More efficient procedures to employ these migrants may serve the interest of the Dutch economy, in particular in case of staffing bottlenecks for employers in 'shortage occupations'. In this subsection we address the following research question: What can the Netherlands learn from Germany to become more attractive for skilled workers from (non) EEA+ countries?

\section{Medium-skilled migration to Germany}

As in the Netherlands, personnel from EEA+ countries can make use of their right to free movement to find a job in Germany. The Skilled Workers Immigration Act (Das Fachkräfteeinwanderungsgesetz) is the most important legal provision for medium skilled workers from non-EEA+ countries. The act was adopted by the German Bundestag in June 2019 and came into force on March $1^{\text {st }} 2020$, expanding the legal framework for skilled migrants from non-EEA+ countries to work in Germany.

Under the Skilled Immigration Act, two groups are considered to be skilled workers: the first group includes those with a higher education degree that is recognised to be comparable to a higher education degree in Germany. The second group encompasses those who have completed qualified vocational training in Germany (usually a two-year period is required) or with a vocational training acquired abroad that is equivalent to German qualified vocational training. Shorter foreign vocational training courses can also be considered if they do not differ substantially or the differences can be compensated for.

On the one hand, the Skilled Immigration Act provides that skilled workers from third countries seeking qualified employment in Germany, have to get their professional or academic qualifications recognised as comparable for entering Germany. There is one exception, IT specialists with "highly-developed practical professional knowledge" do not need recognition to practice their occupation. On the other hand, the Skilled Workers Immigration Act has made the German labour market considerably more accessible for non-EEA+ medium-skilled migrants. The following three dimensions stand out.

- Facilitated access to more occupations on the German labour market. Two measures fostered this better access: firstly, there is no longer a priority-check in place. Previously the Federal Employment Agency had to check if there were any German or EEA+ applicants for the job before accepting a candidate from a third country. This is no longer the case. However, the Federal Employment Agency will still verify the employment conditions meet the usual standards of Germany. Secondly, the 
employment of migrants from outside the EEA+ with vocational training is no longer restricted to occupations with skills shortages. This means that those with a specific job offer and recognised vocational qualifications can now access all occupations they are qualified for and are no longer limited to work in specific shortage occupations.

- Facilitated access for job search in Germany. The Skilled Immigration Act also introduces the opportunity for professionals with vocational training qualifications to go to Germany to look for a job. The prerequisites for this type of residence permit are the following: having their vocational qualification recognised, being able to support themselves for the job search period and possessing the necessary German language skills for the desired occupation (usually B1 level). Those who qualify can be granted a residence permit for up to six months. In this period employment up to ten hours a week on a trial basis is allowed.

- Facilitated access for skill development. The scope for residence for vocational qualification purposes in Germany has been extended by the act through two developments. Firstly, medium-skilled migrants can go to Germany to receive vocational training to compensate for substantial differences that have been established between the foreign degree and the German one during the qualification recognition procedure. Working during such qualification measures is permitted. The permit to get qualified through this system can be extended by up to 24 months to take into account the waiting times for examination and retaking exams. In the case of healthcare nursing professions and other selected professional qualifications, people can come to Germany before the start of the recognition procedure and take up employment in parallel with the procedure. A prerequisite is that they have a job placement agreement in advance between the Federal Employment Agency and the labour administration of the country of origin. A second development that facilitates skill development in Germany pertains to students and trainees. More specifically, nonEEA+ citizens who are interested in receiving vocational training in Germany can, under a few conditions, go to Germany to look for a training place. With a permit for vocational training, migrants are also allowed to follow German language training courses. The act also allows those who completed vocational training in Germany to receive a permanent settlement permit after two years.

\section{Comparison of Germany to the Netherlands}

One important difference between vocational training in Germany and the Netherlands is that in Germany trainees are considered "workers" and receive a salary from the start of their VET. In the Netherlands, however, trainees are more similar to "students" and have to pay tuition fees. The Dutch system could be less attractive than the German system for individuals who seek to obtain their VET abroad as it involves higher costs.

- Reductions in processing times. The Skilled Immigration act also introduced a fasttrack procedure for skilled workers in order to significantly reduce the duration of the administrative procedures for receiving a visa. This means that under specific conditions, employers can apply for an 'Accelerated procedure' for the entry of the 
skilled worker from a third country. The aim is to shorten the qualification recognition procedure to two months. Deadlines regarding approval from the Federal Employment Agency and work visa applications are shortened as well. The costs of the procedure $(€ 411)$ are to be covered by the employer.

In other words, the Skilled Workers Migration Act shapes the access of non-EEA+ medium-skilled migrants who want to work in Germany considerably by specifying to what occupations they can have access, allowing for job search in Germany, facilitating access for skill development and reducing processing times.

Besides these legal provisions pertaining to residence permits, Germany also invested in information provision to attract skilled migrants and facilitate their access to the country. A good example is the website make-it-in-germany.com. This interministerial multilingual website provides information on job opportunities and legal requirements for taking up work in Germany. Another example is the website www.anerkennung-in-deutschland.de. It provides information on the Recognition Act and helps people assess the requirements for exercising their profession in Germany. There is furthermore a hotline where people can get personalised information on their job search in Germany, recognition of qualifications and entry and residency. This hotline received 10,000 calls from people in 145 countries in the first year (Griesbeck, 2014).

The question is of course to what extent these measures were successful in attracting medium-skilled professionals to Germany. This is difficult to establish, also because the Skilled Immigration Act has been in effect for only one year in March 2021, and there have been no formal policy evaluations thus far. Furthermore, the mobility of workers has been restricted by measures in light of the pandemic. In a press release discussing the one-year anniversary of the introduction of the act, the Federal Ministry of the Interior, Building and Community claim that despite the pandemic, 30.000 visas for skilled workers and trainees from third countries were issued. In that light, the Federal Minister Seehofer seems to consider this a successful first year saying that "After only one year, the Act has allowed us to successfully compete for skilled workers by providing people with a legal pathway to the German labour market" (Federal Ministry Of The Interior Building And Community, 2021, p. 1). A critical note was formulated by the OECD (2020) which warns for a competitive disadvantage pointing at the qualification recognition requirements in Germany. After all, most other countries do not demand formal recognition for gaining access to the country, and only assess the level of education. Recognition is usually only required for regulated professions. This recognition requirement therefore could be a major hurdle in fostering a higher influx of skilled migrants to Germany, the OECD claims. Future research would have to establish the effectiveness of the measures implemented. 


\section{The Swedish case}

In Sweden, the labour migration system was reformed in 2008. Before this reform, there had to be "a labour market shortage in the profession for an employer to be allowed to recruit from abroad" (Emilsson, 2014, p. 6). The new law abolished any sort of skill or salary requirement, proven labour market shortages, and numerical quotas. The aim of the reform was to make the system truly employer-led (Siegel et al., 2017, Emilsson \& Irastorza, 2020). This reform made the Swedish system one of the most liberal and open regimes (Emilsson \& Irastorza, 2020).

Before hiring a TCN, Swedish employers first need to advertise the position they need to fill on a national and EU level. If the position cannot be filled by the priority supply, the employers can choose to advertise the position to TCNs. Before hiring a TCN, however, the employer must contact any relevant labour union to ensure the contract is in line with the agreements and conditions within this union (Siegel et al., 2017). Work and residence permits must usually be arranged before the worker leaves their country of origin. These permits are granted for a maximum of two years and can be extended if it is linked to an employer or occupation (Emilsson, 2014; Emilsson \& Irastorza, 2020).

Although the Swedish system has proven to be effective, there are still some shortcomings, as it does not prevent abuse of migrant workers entirely even though the situation has already significantly improved (Parusel \& Tamas, 2016; Siegel et al., 2017; Emilsson \& Irastorza; 2019).

\section{$5.5(\mathrm{Im})$ possibilities for labour migration policy}

The literature review has identified several possibilities to reform or adjust available migration policy tools for the medium-skilled in the Netherlands.

- Introduction of migration policy specifically aimed at the medium-skilled level. This should include more flexible and shorter admission procedures comparable to migration schemes targeting the highly skilled in the Netherlands or the Skilled Workers Immigration Act in Germany. Considering that medium-skilled migrants enjoy a similar status as high-skilled migrants in Germany, emphasising the importance of both groups to the economy, and changing the narrative regarding this group of migrants could also be important. It would be the task of the Dutch Government to communicate the vision that migration beyond the highly skilled benefits the economy (ACVZ, 2019).

- As labour migration to the Netherlands is mostly employer-led the (im)possibilities for labour migration very much depend on their willingness to hire workers from abroad. Prejudices and stereotypes can be an obstacle to matching Dutch demand with foreign supply. For example, there seems to be a common misconception among Dutch employers that the cultural difference between the Dutch and workers from the 
Middle East or Africa is too big to be overcome (Oomes et al, 2019). Therefore, it is important to create awareness among employers that past experiences with employing low-skilled and maybe even illiterate labour migrants from these countries cannot be compared to employing medium- or high-skilled individuals in shortage occupations that are expected to grow in the future (ibid.).

- Based on previous recommendations by the ACVZ (2019), a standing committee could be made responsible for investigating the occupations in excess demand and the opportunities for labour migrants to meet that demand.

\section{Examples from Germany and the United Kingdom}

In Germany, the admission of foreign employees is strongly geared towards the requirements of the German economy, as is laid down in the Residence Act. The Federal Employment Agency plays an important role in identifying shortages on the labour market (and admitting third country nationals). They identify shortages based on statistics on registered vacancies and unemployed persons as well as the survey on national job vacancies carried out by the Institute for Employment Research (IAB). The Federal employment Agency is also responsible for drawing up the so-called 'positive list' with occupations for which it is difficult to find domestic workers, in cooperation with the Federal Ministry of Labour and Social Affairs (Vollmer, 2015).

In the UK, the Migration Advisory Committee is an independent public body providing advice on matters related to migration for the government. Among other things, the Migration Advisory Committee is responsible for analysing which occupations experience shortages and for reviewing the UK's official "Shortage Occupation List" (MAC, 2020). This includes medium- and high-skilled occupations. Recommendations by the Committee are not legally binding and the UK government can diverge from them (Walsh, 2021). For occupations on the shortage list, a lower salary threshold is required for migration to the UK (Walsh, 2021).

- Sectoral policies could be created to address shortages in certain sectors (ACVZ, 2019; De Lange et al, 2019). 


\section{Examples of sectoral or industry-wide migration policies}

Example 1: In Germany, the Internationaler Bund's FIA (Fachkräfte im Ausland, skilled workers abroad) programme works together with companies to find suitable employees abroad. Together, they determine which applicant profile would be a perfect fit for the company. After completing the profile, the FIA programme sets out to find employees in either Italy or one of the Balkan countries. After suitable applicants have been selected by the programme, the company itself decides which applicants to interview and possibly hire. The applicants need to have sufficient professional training or a university degree, and they will be offered an intensive German language course "up to the level required for the recognition of their foreign qualifications" (Internationaler Bund, n.d., translated by authors).

Example 2: Similarly, the Internationaler Bund also sets up the Internationale Migrationsdienste (international migration services), which enables companies to recruit employees from abroad, who are subsequently trained to enter the labour market in Germany. Together with the commissioning companies, a profile of the perfect applicant is created. Usually, the companies that make use of the international migration service are looking for nurses, geriatric nurses, midwives, or teachers, but other occupational fields can also make use of the service. Similar to the FIA programme, the qualifications of the applicants are of particular importance for the selection: they need to have at least the required professional training or a university degree. The migration service offers the applicants a "four-to-five-month intensive language course and communication training related to everyday life and work" (Internationaler Bund, n.d., translated by authors), during which the applicants will reach B1 level German. Additionally, they are able to improve their German to B2 level either internally or externally while working at the company, which is the minimum level required for the recognition of foreign qualifications (Internationaler Bund, n.d.).

Example 3: In Spain, the Fundación Laboral de la Construcción carried out "11 pilot experiences on health and safety in construction and labour legislation for more than 180 migrants and refugees in Andalusia, Las Palmas and Navarra" (Fundación Laboral de la Construcción, 2021, translated by authors) in collaboration with the Spanish Commission for Refugee Aid and the Red Cross. These pilots were part of the In2C project, which is part of the European Commission's Asylum, Migration, and Integration Fund (AMIF) programme. The project also includes institutions from Greece, Cyprus, and Sweden. The aim of the project is to promote the integration of TCNs into the European labour market in the construction sectors by providing professional training and developing a collaborative network between employers and potential employees from third countries to improve recruitment opportunities for migrants and refugees (Fundación Laboral de la Construcción, 2021).

- Improved free movement of TCNs through the expansion of the Single Permit Directive (De Lange \& Groenendijk, 2021).

- Mobility and talent partnerships could be created to expand transnational cooperation for the recruitment of medium-skilled workers. Talent partnerships to address skills shortages as introduced in June 2021 in line with the EU's New Pact on Migration and Asylum could be a possibility for this (Mayer \& Clemens, 2021). The success of these partnerships depends on the support of EU Member States, employers and third countries (Hooper, 2021). So far, the Netherlands does not participate in EU-funded mobility partnerships, but this is recommended if it wants to attract more labour migrants (De Lange 
et al, 2019; ACVZ, 2019). Such partnerships also seem more feasible for employers who are not experienced in recruiting from third countries as they receive targeted support in navigating the recruitment and immigration process of TCN employees (Hooper, 2021).

- More liberal migration policies targeting all migrants disregarding their educational or skills level and occupation (as in Sweden); this could also prevent the emergence of an even more fragmented landscape of migration policies.

\section{Triple Win project to attract nurses to Germany}

The German Development Cooperation (Deutsche Gesellschaft für Internationale Zusammenarbeit, GIZ) and the Ministry for Economic Cooperation and Development have been very active in cultivating bilateral projects aiming to attract more migrants to mitigate labour shortages in specific sectors (i.e. nursing, elderly care). For example, the "Triple Win" project is a programme created to attract skilled nurses and geriatric nursing carers from Serbia, Bosnia-Herzegovina, the Philippines, and Tunisia. This programme is considered especially successful because it "established relationships on a working level, with a variety of actors being involved in the different phases of the project" (The Expert Council's Research Unit (SVR Research Unit)/Migration Policy Institute Europe, 2019, p. 44). The "Triple Win" programme aims to attract professionally trained nurses whose qualifications can be recognised in Germany, by targeting countries that have a surplus of trained nurses. Nurses undergo language and intercultural training in their origin country, and once they arrive in Germany the necessary procedures for recognising their diplomas can be completed much faster. The programme does not only help to fill labour market shortages in Germany, it also decreases labour market surpluses in the countries of origin. Finally, the migrants earn an appropriate salary in Germany, which could also generate more remittances for their countries of origin (The Expert Council's Research Unit (SVR Research Unit)/Migration Policy Institute Europe, 2019). The initial work permit for participating nurses is valid for one year with the possibility of extension. Provided that the nurses' foreign qualifications are recognised and that they have a valid employment contract, it is possible to stay in Germany more permanently (BA \& GIZ, 2019).

Sub-question 4: Which instruments can play a role in bringing the Dutch demand and the foreign supply together? Where do the opportunities and limitations lie in this respect / possibilities and impossibilities for labour migration policy?

Answer:

\section{Available instruments}

- There is no legal instrument available that targets the medium-skilled specifically.

- Medium-skilled migration is possible through various rather restrictive channels.

- The Netherlands has a fragmented migration policy landscape.

\section{Opportunities}

- Migration can be one of the most efficient ways to address skills shortages.

- Migration can lower unemployment in countries of origin and countries of previous residence, e.g. in the case of intra-EEA+ migration of TCNs.

- Migration can rejuvenate the Dutch workforce.

- Posting opens new ways of legal migration. 
- Posted workers officially reside and work in one EEA+ country, but are sent to a second EEA+ country to provide a service for a temporary period of time. This can include the hiring out through a temporary work agency (uitzendbureau).

- The posting of TCN workers does not involve any migration requirements on parts of the country to which the worker is posted.

- Circular migration is a form of temporary migration in which an individual repeatedly moves back and forth between two or more countries, usually for the purpose of labour. Circular migration schemes can be seen as a flexible way to mitigate skills shortages and curb irregular migration.

\section{Limitations}

- Migration cannot be the only solution to filling skills shortages.

- Restrictiveness of available instruments and lengthy procedures make it difficult to respond to shortages.

- Migration is very much dependent on employers, who often prefer alternative solutions to recruiting migrants, e.g. due to remaining prejudices and stereotypes.

- The procedures for the recognition of foreign qualifications are expensive and lengthy.

- Employers can (ab)use posting to save labour costs.

- More specific information on the trends and dynamics of posted work to the Netherlands is scarce and we could not identify any literature that covers the posting of TCNs working in the three focus sectors.

\section{Possibilities}

- It could be possible to improve the free movement of TCNs through the expansion of the Single Permit Directive.

- There are possibilities to introduce a migration policy specifically aimed at the mediumskilled level, like the Skilled Workers Immigration Act in Germany.

- The relatively new Skilled Workers Immigration Act in Germany (in effect as of March 2020) establishes access to certain occupations for non-EEA+ migrants with intermediate qualifications, enables them to find work in Germany, facilitates skills development and shortens processing times.

- A standing committee could investigate labour demand and supply, and the opportunities for labour migrants to meet excess demand.

- Sectoral policies could be created to address labour market shortages.

- Mobility and talent partnerships could be created to expand transnational cooperation for the recruitment of medium-skilled workers.

- More liberal migration policies targeting all migrants disregarding their educational or skills level and occupation could be copied from Sweden; this could also prevent the creation of an even more fragmented labour migration landscape.

- Increasing the awareness of benefits of migration among employers and the general public could further help to increase the recruitment of medium-skilled workers.

- The phenomenon of posting does concern Eastern European workers as well as a large share of posted workers coming from Western EU Member States being posted to other Western EU Member States. TCNs with a valid work and residence permit in one EEA+ country can also be posted across the EEA+.

- Intra-EEA+ posting of TCN workers is on the increase and this mainly concerns lowand medium-skilled workers.

- Circular migration is associated with benefits for migrants themselves, as well as their host and home countries, although these are subject to debate.

\section{Impossibilities}

- It is not sufficient to design migration policies to attract medium-skilled workers, it is also important to integrate them into Dutch society. 
- Although there are some indications that the Skilled Workers Immigration Act has been successful in fostering a higher influx of skilled migrants to Germany, the recognition requirement could be a major hurdle.

- The Swedish system can be a good example for the Netherlands. It has proven to be effective, although there are still some shortcomings, such as the abuse of migrant workers.

Different procedures are in place for Foreign Qualification Recognition as an instrument to bring the Dutch demand and the foreign supply together in the three focus sectors

- The procedure for recognition of professional qualifications applies to those with a non-automatically recognised qualification obtained in a non-EEA+ country.

- Firstly, getting the qualifications recognised in healthcare occupations can be quite a lengthy process, especially for holders of degrees from outside the EEA+ countries. The recognition procedures turn out to be complex and often poorly understood by TCNs, making identifying recognition options, pathways and alternatives challenging.

- Secondly, there is a high dropout rate in the process.

- For the metal and energy transition sectors, there are no regulated occupations on mbo level-4 for which qualification recognition is mandatory. Relevant for migrants who want to work in unregulated occupations is foreign credential evaluation. This can give a good indication of the value of a foreign diploma in the Netherlands and can be used both for finding fitting employment and finding a suitable study.

- A last type of recognition is the so-called validation of prior learning (VPL, in Dutch Erkenning van Verworven Competenties, EVC). The value of the VPL highly depends on employers and educational institutes endorsing and accepting the VPL certificates. This policy instrument falls under the strategy of lifelong learning. VPL can be used for two routes:

- In the labour market route, prior learning outcomes of individuals are validated against sector or organisation standards.

- For the education route of VPL, applicants validate their formally/informally/non-formally acquired competences as a step to obtaining a formal qualification. 


\section{Alternative solutions to staffing bottlenecks in the middle segment of the Dutch labour market}

Migration can be one way of mitigating skills shortages including at the upper secondary vocational level of the Dutch labour market. Mayer and Clemens (2021) argue that migration is the measure that takes effect most instantly. Nevertheless, it cannot be the only solution (European Commission, 2015). Therefore, this section provides an overview of alternative solutions to fill the identified shortages in the middle segment of the Dutch labour market as mentioned in the reviewed literature. The questions related to this section refer to sub-question 5 of the introductory section of this report: Have other possible solutions been mentioned for the identified shortages in the middle segment of the Dutch labour market? If so, which?

Organisations facing labour shortages will usually initiate so-called adjustment processes. In competitive labour markets, adjustment processes, such as wage increases, may be the result of the market mechanism. However, there are many deliberate policy measures to alleviate bottlenecks in labour supply. Some of these are presented in the table below. Overviews of creative solutions to solve recruitment problems can be found in reports by PBL \& ROA and UWV. ${ }^{32}$ We also look at the policies used by employers in the three focus sectors. Furthermore, the report on bottleneck vacancies by Pitukhina et al. (2020) is relevant for outlining strategies to reduce shortages in these sectors. Strategies to cope with skills shortages and to overcome staffing bottlenecks require both comprehensive policy adjustments at the sectoral or national level and targeted HR policies within firms. Subsection 6.1 further discusses these. Subsection 6.2 specifically discusses the strategies for the three focus sectors of this report, and concludes with a comprehensive overview of sectoral policies to tackle skills shortages.

\subsection{National and firm strategies to tackle skills shortages}

At the national level, various successful approaches have been taken to better match labour supply and demand in order to encourage people to study and work in specific areas with obvious shortages, such as STEM, ICT and R\&D. In this matter, the Netherlands has set an example back in 2013 with the establishment of the National Technology Pact (Techniekpact), a partnership between public and private sectors to attract more people in highly technology studies and sectors (CEDEFOP, 2016). The policy has had positive results with an expected further increase of around 10,000 new candidates entering in the STEM field by 2025 , solely due to this initiative (stemcoalition.eu, $2018^{33}$ ). This model has inspired other EEA+ countries, such as Denmark in 2018 and Germany, to start a similar initiative. Companies and employers can mitigate the effects of skills shortages in hard-to-fill vacancies through human resource management. Furthermore, there is ample evidence that tailored approaches to human resource management and development have helped to marginalise the negative effects of skill shortages in different industries. The use of

32 See for policy suggestions page 29-32 of the PBL \& ROA report (Weterings et al., 2019) on the energy transition. See also UWV (2018).

33 See www.stemcoalition.eu/publications/pact-attract-10000-more-stem-candidates-2025 
different recruitment channels (such as employment agencies and other intermediaries, cross-border postings) can also be helpful in filling vacancies.

Table 18 lists the different strategies to solve hard-to-fill vacancies. Hiring difficulties may be attributable to inadequate human resource strategies and practices. Unattractive reputation of the industry, together with low pay and unclear career pathways for new hires may be a strong discouraging factor that keeps potential new candidates from choosing to enter the industry. On the demand side, we can distinguish between strategies that focus on changes in the required skills and work organisation in occupations with shortages, on improving working conditions and rewards in recruitment strategies, and by searching for staff in other labour segments and through other channels. Compensation, recruitment parameters and job structuring should be re-examined as components of a skills gap strategy. For instance, firms could widen their candidate pool by loosening up the requirements for technical skills towards emphasis for attitudinal characteristics. Strengthening the marketing for promising career pathways should go alongside the strengthening of the training system.

On the supply side, we can distinguish between strategies aimed at offering new training courses or designing new training programmes, and strategies reducing institutional barriers by introducing more efficient education, training and recruitment arrangements. It should be noted that these strategies are usually not specific to the middle segment of the labour market, apart from measures that can be taken to improve the vocational training and education (VET) system and promote the recruitment of (VET) apprentices.

Table 18: Strategies to solve hard-to-fill vacancies

\begin{tabular}{|c|c|c|}
\hline Strategies & Explanation & References \\
\hline $\begin{array}{l}\text { Demand side: } \\
\text { Changing job tasks and } \\
\text { requirements }\end{array}$ & $\begin{array}{l}\text { Changes in required skills and work } \\
\text { organisation in occupations with } \\
\text { shortages }\end{array}$ & \\
\hline Optimizing organisation of work & $\begin{array}{l}\text { Changes enacted within organisations } \\
\text { or within employers' control, including } \\
\text { job crafting, off-shoring and } \\
\text { outsourcing, raising prices for goods } \\
\text { and services, (temporary) production } \\
\text { closure or postponing production }\end{array}$ & $\begin{array}{l}\text { Ho, 2016; Sharma et al., } \\
\text { 2016; Healy et al., 2015; } \\
\text { Ashton, } 2018\end{array}$ \\
\hline Work reorganisation & $\begin{array}{l}\text { Short-term and less costly solutions, } \\
\text { such as adoption of flexible working } \\
\text { hours and increases in overtime hours, } \\
\text { increase of working hours of part-time } \\
\text { workers, greater reliance on flexible job } \\
\text { design and part-time workers, and } \\
\text { implementation of self-directed work } \\
\text { groups and problem-solving teams }\end{array}$ & $\begin{array}{l}\text { Fang, 2009; Jacob et al., } \\
\text { 2015; Drennan et al., 2018; } \\
\text { Aithal and Aithal, } 2017\end{array}$ \\
\hline $\begin{array}{l}\text { Automation and technological } \\
\text { investments }\end{array}$ & $\begin{array}{l}\text { Automation of tasks (i.e. higher capital } \\
\text { intensity) is one strategy to reduce } \\
\text { and/or change the need for labour; this } \\
\text { also holds for robotisation and } \\
\text { digitalisation }\end{array}$ & $\begin{array}{l}\text { Gindele et al., 2016; } \\
\text { Richards-Carpenter, 2016; } \\
\text { Ho, 2016; Healy et al., } 2015\end{array}$ \\
\hline
\end{tabular}




\begin{tabular}{|c|c|c|}
\hline $\begin{array}{l}\text { Demand side: } \\
\text { Changing the working } \\
\text { environment }\end{array}$ & $\begin{array}{l}\text { Improving working conditions and } \\
\text { rewards }\end{array}$ & \\
\hline $\begin{array}{l}\text { Raising wages and work } \\
\text { conditions }\end{array}$ & $\begin{array}{l}\text { Raising wages and improving labour } \\
\text { market terms and conditions, and } \\
\text { career opportunities; however, } \\
\text { increasing pay does not automatically } \\
\text { predict retention }\end{array}$ & $\begin{array}{l}\text { Cairncross \& Kelly, 2018; } \\
\text { Ho, 2016; Weyman, } 2019\end{array}$ \\
\hline Organisational culture & $\begin{array}{l}\text { Management quality (of managers and } \\
\text { the broader institutional culture) is } \\
\text { central to shaping the opportunities } \\
\text { made available to, and the incentives } \\
\text { for, employees to participate in skills } \\
\text { development and to utilise their skills in } \\
\text { the workplace }\end{array}$ & $\begin{array}{l}\text { Lyons et al., 2020; Coventry } \\
\text { et al., 2015; McGuire et al., } \\
\text { 2017; Ashton, } 2018\end{array}$ \\
\hline $\begin{array}{l}\text { Employee involvement and } \\
\text { workplace support }\end{array}$ & $\begin{array}{l}\text { The evidence suggests that the } \\
\text { strength of employee involvement and } \\
\text { the nature of workplace support are } \\
\text { strongly associated with employees' } \\
\text { willingness and ability to come up with } \\
\text { new ideas }\end{array}$ & $\begin{array}{l}\text { Felstead et al., 2020; Aithal } \\
\text { \& Aithal, 2017; Ho, } 2016\end{array}$ \\
\hline $\begin{array}{l}\text { Demand side: } \\
\text { Changing recruitment strategies }\end{array}$ & $\begin{array}{l}\text { Searching for personnel in other labour } \\
\text { segments and through other channels }\end{array}$ & \\
\hline Alternative recruitment strategies & $\begin{array}{l}\text { New recruitment strategies through } \\
\text { increased effort or using new methods, } \\
\text { including better employer branding }\end{array}$ & $\begin{array}{l}\text { Winterbotham et al. 2018; } \\
\text { Sharma et al., } 2016\end{array}$ \\
\hline Recruitment of the unemployed & $\begin{array}{l}\text { Tapping into labour market reserves of } \\
\text { unemployed and inactive persons. } \\
\text { Stigma effect of unemployed only for } \\
\text { the low- and medium-skilled, not highly } \\
\text { skilled }\end{array}$ & $\begin{array}{l}\text { Eriksson and Rooth, } \\
\text { lum } 2014\end{array}$ \\
\hline Reliance on social networking & $\begin{array}{l}\text { Recruitment by word of mouth; long- } \\
\text { term effect especially in the case of } \\
\text { recruitment through migrants and } \\
\text { access to co-ethnic labour pool }\end{array}$ & $\begin{array}{l}\text { Bloch and McKay, 2015; } \\
\text { McCollum and Apsite- } \\
\text { Berina, } 2015\end{array}$ \\
\hline $\begin{array}{l}\text { Use of intermediaries such as } \\
\text { temporary work agencies }\end{array}$ & Use intermediaries to hire personnel & McCollum and Findlay, 2018 \\
\hline $\begin{array}{l}\text { Attract potential workers of new } \\
\text { labour market segments }\end{array}$ & $\begin{array}{l}\text { Better informing youngsters and } \\
\text { unemployed persons about attractive } \\
\text { jobs in demand, employer branding }\end{array}$ & $\begin{array}{l}\text { Goh \& Okumus, 2020; Ho, } \\
2016\end{array}$ \\
\hline $\begin{array}{l}\text { Recruitment of overqualified } \\
\text { graduates (including from abroad) }\end{array}$ & $\begin{array}{l}\text { Recruiting graduates who are more } \\
\text { highly qualified than is necessary for } \\
\text { the job tasks involved; employers may } \\
\text { rearrange the job in question to } \\
\text { separate more from less complex tasks } \\
\text { and to better utilise the skills of } \\
\text { graduates for the required tasks }\end{array}$ & Lewis, 2013 \\
\hline $\begin{array}{l}\text { Extending the geographical reach } \\
\text { of the recruitment process }\end{array}$ & $\begin{array}{l}\text { Tapping into labour market reserves of } \\
\text { other regions in the country }\end{array}$ & Healy et al., 2015 \\
\hline
\end{tabular}




\begin{tabular}{|c|c|c|}
\hline $\begin{array}{l}\text { Supply-side: } \\
\text { Training and upskilling of workers }\end{array}$ & $\begin{array}{l}\text { Providing new training courses or } \\
\text { designing new training programmes }\end{array}$ & \\
\hline $\begin{array}{l}\text { Increased training of existing staff } \\
\text { and/or expand trainee } \\
\text { programmes }\end{array}$ & $\begin{array}{l}\text { Increasing training efforts and } \\
\text { participation; usually a medium- to } \\
\text { long-term solution for shortages }\end{array}$ & $\begin{array}{l}\text { Gambin, Hogarth, Murphy et } \\
\text { al., } 2016\end{array}$ \\
\hline $\begin{array}{l}\text { Re-skilling from adjacent } \\
\text { professions }\end{array}$ & $\begin{array}{l}\text { Providing training (vocational, general) } \\
\text { programs to persons with lower or } \\
\text { other educational backgrounds and } \\
\text { lack of required skills }\end{array}$ & Stephany, 2021 \\
\hline $\begin{array}{l}\text { Retaining and engaging older } \\
\text { workers }\end{array}$ & $\begin{array}{l}\text { Older workers who desire to continue } \\
\text { working constitute a significant labour } \\
\text { source for mitigating the emerging } \\
\text { shortages of skilled workers }\end{array}$ & Heisler, 2016 \\
\hline $\begin{array}{l}\text { Supply Side: } \\
\text { Reducing institutional } \\
\text { impediments }\end{array}$ & $\begin{array}{l}\text { More efficient arrangements for } \\
\text { education, training and recruitment }\end{array}$ & \\
\hline $\begin{array}{l}\text { Large and targeted-use of } \\
\text { apprenticeships }\end{array}$ & $\begin{array}{l}\text { Co-designing apprenticeships with } \\
\text { business service sectors }\end{array}$ & $\begin{array}{l}\text { Smits and Zwick, 2004; } \\
\text { Riley et al., } 2020\end{array}$ \\
\hline Validation of Prior Learning (VPL) & $\begin{array}{l}\text { Speeding up and simplify diploma } \\
\text { recognition and recognition of prior } \\
\text { learning }\end{array}$ & ILO, 2018 \\
\hline Reduce number of transitions & $\begin{array}{l}\text { Enact policies and practices that } \\
\text { ensure that apprentices are retained by } \\
\text { the employers that have invested in } \\
\text { them }\end{array}$ & $\begin{array}{l}\text { European Commission, } \\
\text { 2020c; Gambin and } \\
\text { Hogarth, } 2016\end{array}$ \\
\hline Government wage subsidies & $\begin{array}{l}\text { Encourage hiring or retention of certain } \\
\text { subgroups to compensate for the gap } \\
\text { between pay and productivity involved } \\
\text { in employing them }\end{array}$ & $\begin{array}{l}\text { Boockmann, 2015; Barrett } \\
\text { et al., } 2014\end{array}$ \\
\hline Public Private Partnerships & $\begin{array}{l}\text { Collaborate with local or regional } \\
\text { partners to draw on existing } \\
\text { experience, to enable the sharing of } \\
\text { processes and/or costs associated with } \\
\text { international recruitment }\end{array}$ & $\begin{array}{l}\text { NHS Employers, 2020; } \\
\text { Barrett et al., 2014; Pan et } \\
\text { al., 2019; OECD and ILO, } \\
2017\end{array}$ \\
\hline
\end{tabular}

Source: Partially based on the PBL \& ROA report (Weterings et al., 2019) and UWV (2018), and the various references mentioned in the table

\subsection{Strategies to tackle skills shortages in the three focus sectors}

\section{Bottleneck solutions for the Metal sector}

\section{In-house training for a T-shaped skill set}

Companies in the steel sector should focus on horizontal skill sets rather than high specialised profiles, mainly because a workforce that is flexible and capable to move across multiple tasks 
is better capable to adjust to increasing changes in the composition of employment and taskspecific requirements in their respective job (Branca et al., 2020, p. 15). The T-shaped skill set is the identification of competencies in which a worker's specialty is complemented with a series of transferable skills; in other words, identifying "people possessing both functional/disciplinary expertise and ability to apply knowledge across different contexts" (Barile et al., 2012, p. 161).

In doing so, leverage on a mixed composition of skills enables workers to become more resilient to changes in technological upgrading and automation, besides contributing to their lifelong learning process. Not only this approach to mixed skillset has been proven effective against the disruptive effects of technological uncertainty (Hamdi et al., 2016), but also a promising roadmap for upgrading university curricula towards preventing staffing bottlenecks and increasing skill set resilience (Ing, 2008; Falkenstein-Smith et al., 2016). Keeping up with the digitalisation process requires jobs that are increasingly interdisciplinary in terms of teams, tasks and thinking. In conclusion, it is important to provide workers with necessary skills to move easily from one specialty to the other (Skevi et al., 2014).

\section{Advancing human resource strategies}

There are a set of actions related personnel policy strategies that employers have pursued in the metal sector to mitigate future staffing bottlenecks. These can be considered as examples of the strategies that have been mentioned in Table 18 before.

- Tap into disadvantaged labour segments. Mainly the inactive labour population such as unemployed or disabled individuals: it has been shown that private employment programmes are as effective in reintegrating the unemployed as public efforts, while providing, at the same time, tangible benefits to the firm. (Gerards et al., 2014) For instance, Philips offers 140 positions and apprenticeship trajectories to disadvantage segments each year. Also VDL Nedcar, a car manufacturer in Born has filled many job vacancies with unemployed people in recent years, in collaboration with municipalities, UWV and temporary employment agencies (Dijksman et al., 2017).

- Intensify cooperation and staff exchange with education institutes. Establishing cooperation will enable to attract, develop, and retain competent technical employees while they are still in education. For instance, the project Jet-Net \& TechNet aims at increasing the interest towards technical vocational occupations through training courses and open days. More broadly, the creation of an ecosystem in which stakeholders from private companies, vocational schools and government bodies cooperate will create the infrastructure to enable adequate conditions to mitigate future staffing bottlenecks in all three critical sectors. For instance, an enabling ecosystem may facilitate the flow of older employees from the metal and electrical sector to teaching positions in vocational education. Additionally, companies may offer part-time jobs to students enrolled in technical studies, so as to allow students to acquire some relevant experience that matches with their studies, given that there are many students in part-time jobs that do not match their education (Dijksman et al., 2017).

- Strengthen the capacity of Public-Private Partnerships. A widely discussed solution to systemic problems such as skill shortage in the face of uncertain cyclical manufacturing demand, is to combine public subsidies with strategic collaborations 
among industry employers. Several employers agree to co-invest in training consortium in strict supervision and collaboration with the public sector, together with unions and higher education institutes. There are several examples to corroborate the effectiveness of Public-Private Partnerships on the topic in the Netherlands.

- Duurzaamheidfabriek, a triple helix partnership in which the public and private sector collaborate to stimulate innovation and to create a hybrid learning environment through shared facilities to train employees and more, allowing continuous interaction between industry and school.

- HighTechCentreDelft, a training facility initiated by companies and the local vocational schools, in which companies and schools collaborate on joint projects, offering both sides benefits, as it links the demand of companies to the learning programs of the educational institutions involved. Companies provide real-life issues and assignments. The facility encourages students to use the latest techniques and to learn by doing.

- Brainport Industry College (BIC) in Eindhoven is a platform initiated by a partnership between local companies with the aim of bringing industry and vocational training institutes closer together through different initiatives to stimulate a hybrid learning environment. Brainport initiated a code of conduct between SMEs of the specific industry. Among others, the code of conduct includes agreements on providing training opportunities for students in the form of practical internships. Hence, this ensures stability despite economic differences and therefore builds trust between the parties of SMEs, the BIC and students both benefit from the agreement to support competence development that is relevant in the economic industry.

- Fieldlab Industrial Robotics is an initiative established by a modern Dutch company called AWL Techniek, whereas Fieldlab Industrial Robotics is a cooperation to bring closer together employers and VET schools. Fieldlab Industrial Robotics offers to local (T)VET institutions to use and to create valuable up-to-date curricula.

- Verbonden met Zuid, a project bringing together early school leavers and employers with vacancies to fill and education providers. Jointly, apprenticeship programs are designed for unemployed young adults, through the support of European funds.

- A broader sector approach is illustrated in the United States, with The Wisconsin Regional Training Partnership (WRTP), known as a membershipbased consortium of employers, unions, and public agencies, with over 100 members. WRTP provides a wide range of services related to training, such as pre-apprenticeship and pre-employment training and certification and operates as intermediary to facilitate retraining at the sectoral level. (Kimmell \& Martin, 2015, p. 21)

- Targeted training subsidies to small enterprises. Smaller firms are more likely to experience hiring challenges because they serve smaller markets and therefore require more specialised skills to work with equipment not widely used in the industry; at the same time, smaller firms are also more likely to not being able to capitalize on economies of scale and thus have less capacity to invest in training or recruitment (Kimmell \& Martin, 2015). Targeted public subsidies can help small enterprises to 
embark in specialised training. A more profitable perspective can be to allow employees to receive funding for specific training in exchange for a minimum job continuity in the firm that provided the training, with the alternative of having to repay the subsidy if the employee decides to change employer.

- Following the trend of automatisation: Adapting to technological change. Digitalisation is enforcing a re-organisation of work, leading to job polarisation: computer technology augments the productivity of the highly skilled (i.e., computer engineers) and leaves untouched the least skilled, because non-routine work is untouched from new technologies (European Commission, 2019). Downey (2021, p. 1) argues that variations in minimum wage can intervene towards regulating the speed with which technological automation can substitute routine tasks properly for middleskilled workers. The minimum wage raises these costs, lowering the profitability of automation and slowing the adoption of routine-replacing technologies.

\section{Bottleneck solutions for the Energy Transition sector}

As the energy transition sector comprises a variety of very heterogeneous subsectors, we present below some examples of sectors where the staffing bottlenecks are being addressed in an appealing way.

\section{Example 1: Solutions for the wind energy industry}

The two central problems of a skill gap in the wind energy industry can be attributed to a shortage of technical skills in Operations \& Maintenance (O\&M) and a general shortage of STEM graduates in the economy. The two most quoted improvements suggested from the European Wind Energy Technology Platform (Fitch-Roy et al., 2013) were a promotion of shorter, more targeted training courses, and an increased role for industry in academic training. Key industry stakeholders within the energy industry were interviewed and proposed the following solutions (Fitch-Roy et al., 2013).

- Promotion of shorter and flexible vocational training courses. Many of the experts considered full length academic programmes not much beneficial compared to shorter ones, which suggests the need for more flexible vocational training that can be structured around full-time employment, through employer funding.

- Promotion of collaboration between industry and academics. Promotion of knowledge transfer between the wind industry and academic institutions. This can be accomplished by encouraging industry and universities to jointly fund internships and industrial scholarships to encourage the flow of graduates in the industry.

- Encouraging more industry input into academic courses in the relevant discipline. This may be achieved partially by increasing the number of lecturers and trainers with direct wind industry experience. There is evidence of lack of qualified trainers which is an impediment in the further strengthening of vocational education. A stricter collaboration between energy companies with training institutes may be a stepping stone to improve the situation.

- Harmonisation of VET in the European context. Vocational education can be better harmonised, namely improving coordinated dissemination of appropriate educational content and techniques to more adequately meet industry needs. 
A well-planned national education and training strategy needs to be in place to oversee the progressive introduction of adequate curricula and favour the development of a skilled energy-sector workforce. Universities and education institutes can be incentivised to increase renewable energy research and curricula, either via direct funding, such as government financing towards energy-focused research, or either indirectly, via public-private partnerships, or introduction of research fellowships, research equipment, grants and vocational training programmes that meet both local and national forecasted skill needs. With a particular focus on vocational education, consideration should be given to introducing into the formal apprenticeship system the recognition of new occupations, such as qualified electrician or operations and maintenance technician. Employers also play a role in the training of workers. To counteract the risk of losing their investment, it is suggested that they set up investment programmes together with other employers, such as dual education systems that combine apprenticeships in companies with vocational training classrooms.

A vivid solution for the wind energy sector was initiated by the EU's Windskill project between 2006-2009, with the intention to develop a qualification framework for O\&M in onshore and offshore projects. This project was not materialised but the recommendations were integrated in the newly established German Training Center for Renewable Energies (BZEE) (Ferroukhi et al., 2013, p.84). The BZEE offers training programmes for wind energy technicians, and has expanded its scope towards other countries, mainly France and Canada, through BZEE's Global Training Partnerships.

Renewable Energy (RE) technologies and skills requirements are fairly uniform internationally, so there is an opportunity for standardizing the qualifications requirements. Transnational networks may allow the acceptance of qualifications issued by institutions abroad, this way facilitating international mobility of workers in sectors with high workforce shortage.

\section{Example 2: Education and training in the Technical Installation sector}

Employment in the technical installation sector in the Netherlands is expected to grow, but the figures of mechanical technicians is not high enough to meet the demand of the growth. A large proportion of Technical Installation ( $\mathrm{TI}$ ) professionals are lateral entrants with a technical background from other related sectors. Recruitment of staff from outside the TI industry is seen as an opportunity for employers. In this way, companies acquire new professional knowledge and establish contacts with other related industries. Furthermore, TI companies are willing to train new employees, but research has shown that this usually depends on the motivation, interest, suitability, age and technical background of the employee on a case-bycase basis (Vermeulen et al., 2018, p.27).

Alternatively, the development of an Associate Degree programme is an important achievement to highlight as a way to foster the formation of a medium-skilled workforce needed in the TI sector. The Associate degree is positioned between mbo level-4 and the bachelor level (level 5 of the NLQF, the Dutch framework for qualifications); according to the Veerman committee, the programme "fills and important gap in the Dutch higher education system" 
(Vermeulen et al., 2018, p.57). The two-year Associate degree programmes fit in well with the pursuit of flexibilisation of higher education and strengthening adult participation.

\section{Example 3: Solutions for the sustainable construction sector}

Staffing bottlenecks in the construction sector have been widely documented and can provide valuable insights for skill shortage challenges in the sustainable construction and energy efficiency industry. The volatile nature of the sector is conducive to non-standard forms of employment, such as the use of migrants and self-employed contracts which only worsens the condition to attract middle-skilled workers, because workers with intermediate skills tend to be recruited on a project-by-project basis (Farmer, 2016).

International research on skill shortages in the construction industry point out several solutions that can be generalised beyond geographic-specific situations. Experience from Hong Kong (Ho, 2016) and the United Kingdom (Barrett et al., 2014) provide key recommendations applicable in the Dutch sustainable construction industry environment. Research draws attention to several dimensions of intervention, mainly: provision of tailored training programs, improvement of HR strategies to guarantee long-term employment prospects, the use of tailored governmental subsidies, stronger public-private partnerships, and the embracement of new technologies. These are discussed below.

- Training and Sustainable Employment. Most of the return of investments from training in the construction industry derives from establishing appropriate skill pipelines via quality apprenticeships and from promoting trainability of workers through adequate long-term employment prospects with clear career paths. Employers in the construction sector are less likely than average to train their employees (see also Section 3), because of the project-based nature of the job, along with several other factors, such as the tendency of intermediate skilled workers to become self-employed and therefore seeing no return of investments in specific training, and the risk of poaching from competitors with consequent loss in investment (Dromey \& McNeil, 2017). Attention is rarely devoted towards bringing the skills of workers beyond a minimum necessary to fulfil the job, so little attention is paid to developing their skills further. Poor reputation of the construction industry brings about a negative view that disincentivizes potential trainees to pursue careers in the industry. In this matter, quality training is paramount. Offering apprenticeships within a group of firms has multiple benefits, such as granting firms the ability to share the costs while also allowing the apprentice to mature proficiency in a variety of tasks relevant to crafting their professional profile in the specific industry (Abdel-Wahab, 2012).

Quality training should make use of joint union-employer funding to further develop specific kinds of training courses, while allowing the possibility to integrate the use of virtual learning environments. The latter is useful to minimize the time spent by employees that is paid by their employers, which is often the reason for not undertaking training of employees in the first place. Collaboration between employers in construction and building sectors is also relevant in this context, because alignment of expectations ensures provision of industry-specific skills. 
Training schemes that last for a few months and trainees may carry a financial burden during the training period. To avoid dropouts, one of the key issues for attracting more trainees is providing sufficient targeted subsidies during the training period, which should be increased to two-thirds of the average skilled worker wages (Ho, 2016). Moreover, financial aid is not sufficient alone; a mentoring system to provide practical advice to trainees can help them to not only to sustain the industrial training, but also to nurture further attractiveness to the profession and, possibly, retention to the firm itself. The subsidy and mentoring provision should be extended also to middle-skilled migrants so as to increase the chances of recruitment and retention.

Sustainable employment entails providing an appealing career prospect to workers in the industry, along with the reassurance on the worthiness of professional investment. This can be tackled via multiple sources.

From the construction client point of view, construction clients should be obliged to include a contractual provision that requires contractors, either directly or indirectly through subcontractors, to employ at least one-third of the total workforce on a longterm employment basis. In this way, firms are nudged to become professionally oriented companies (Ho, 2016), portraying stable income prospects and clear career advancement roadmap with hopefully a good working environment that can attract young people to the industry.

From the companies themselves, sustainable employment can be guaranteed by improving safety and welfare, such as including 'pay-for-safety' schemes under which construction clients devote a percentage of the contract sum for the contractor's effort to ensure the safety of workers.

Lastly, from the government perspective, being among the biggest clients in the construction industry. The government can include specific clauses in infrastructure projects that should account for the structural shortage of skills, pushing firms to uphold internal employment standards against worsening labour shortage problems.

Furthermore, accreditation requirements may constitute an institutional barrier for skilled workers. Brydon and Dachis (2013) found that in Canada, although requiring accreditation may drive up pay for those who are skilled, it also acted as a barrier to entry. There should be a greater focus on regulation and assessment of the quality of work done, rather than on the inputs in terms of the qualifications of those doing the work. This will constitute a decisive aspect if deploying labour migrants for intermediary skills requirements.

- Human resource strategies. Recruitment is the most classical strategy to obviate the shortage of qualified workers with specific skills. A particular form of recruitment called the 'Core-periphery model of recruitment' is of special interest for the specific configuration of the construction sector.

Marriott and Moore (2014) discovered that for skilled craft-based jobs, recruitment was often based on assessing candidates during their probationary period. Such methods of recruitment based on the division of an employer's workforce into a core and periphery can be leveraged upon also to promote the employment of medium-skilled migrants.

Friberg (2011) found that construction companies in Norway had a clear but informal division among their employees, with the core staff largely consisting of Norwegian workers and the peripheral staff of migrant workers. The division of tasks was also 
clearly distinct in terms of complexity, with the Norwegian workers deployed for more complex highly skilled tasks. If a peripheral worker was found to be particularly good, they would be moved into the core workforce. This is functioning as a recruitment channel while allowing the employer to minimize the risks of employment. In such circumstances, other skills (i.e., language skills, soft skills, organisational culture fit) could also be assessed through employment. Caro et al. (2015) found that in Finland, Germany and the Netherlands, large companies functioned as the main contractor while small and medium companies and employment agencies located abroad served as subcontractors and provided labour. By providing extra protections to workers with intermediate skills, it can function as a way to recruit workers through informal channels as a way to address skills shortages.

- Stronger Public-Private Partnerships. Orchestrated collaboration between multistakeholders is a primacy for long-term solutions. Barrett et al. (2014) suggested several recommendations to tackle the skill shortages in the construction industry, and most of these entailed some form of public-private partnership. For instance, embedding employment requirements in public procurement contracts together with spurring quality apprenticeships require strategic collaboration. Menz (2011) illustrated how the lack of collaboration between employer and building sector poses problems in upskilling the workforce adequately, which has trickle down effects on the attractiveness of the industry for middle-skilled workers.

Co-design of apprenticeships with the business sector is seen as positive by employers in the professional and business services sector since it broadens their recruitment base, better tailor curricula to the industry needs of new technologies and possibly obviate future skill shortages (Riley et al., 2020).

There are several examples of public-private partnerships, among these the collaboration between training institutions in construction which launched a joint platform (bouwopleiders.nl) dedicated to school pupils, school leavers and graduates, who are interested in a career in construction, providing them information and advice on the training offer in the construction sector (European Commission, 2020c).

- Investing in Modern Methods of Construction (MMC). A further way to reduce skill shortages is to reduce the demand of labour in the first place, by advancing deployment of new technologies. Reducing the labour demand requires enhancing construction productivity by adopting new construction technologies and techniques. MMC strategies are associated with the adoption of pre-manufacturing technologies, digitisation and IT literacy, which require investment in skills of construction workers. Adoption of MMC reduces the requirements for some types of labour and migrant workers but makes migrant workers with experience in MMC more attractive (Davies et al., 2018). The main obstacles are that most projects are still procured under traditional methods, meaning that the type of technologies will define the type of employment. Furthermore, MMC requires investments. However, a solution would be to include the requirement to tackle shortages as part of the evaluation criteria of construction, in order to nudge towards the adoption of MMC. 


\section{Bottleneck solutions for the Healthcare sector}

Many of the recommended human resource development policies for the healthcare sector are like the ones already recommended in the general first part of this section, and are also similar to the previously mentioned sectors, with only a few slight differences.

- Creating a new mid-professional role. Monicca et al. (2016) illustrated the case of South Africa and an effective human resource strategy used by the National Department of Health to tackle the shortage of skilled healthcare professionals. As several of these professionals were migrating abroad, a new mid-level healthcare provider figure was established to perform an important part of the medical work required. This figure corresponds to the international equivalent of a physician assistant in the United States and non-physician clinician in the United Kingdom. The development time to have such a figure established would take time as it would have to be framed within the educational and vocational qualification system, but it is a policy option worth exploring. The decision to establish a new mid-level professional role may re-invigorate the attention and aspiration of young adults to pursue a career which is requalified under new definitions and societal needs.

- Adequate rewards. Even though pay is not the main reason people choose to work in health and social care, proper pay is still a factor that may determine whether workers decide to remain in the sector in the long term. Rewards can come in different forms, such as non-financial incentives but also financial support for individuals that do not have the means to train (Beech et al., 2019). A specific study in the UK confirmed that pay competitiveness does indeed drive down vacancies of nurses. Furthermore, it was found a negative association also between self-reported work environment and measures of burnout and intentions to quit (Combes et al., 2018). Hence, improvements in the workplace should go beyond simple pay raises and be more holistic to retain skilled staff.

- Transforming the hospital work environment. Hospitals and care homes should undergo a redesigning process that also engages and supports the work of nurses, where patient care is enhanced, and vitality is nurtured. Small re-organisations of work may improve work engagement. Transforming Care at the Bedside is a collaborative project between the Robert Wood Johnson Foundation in the U.S. and the Institute for Healthcare Improvement, which involved thirteen hospitals in a pilot project for medical nurses to improve work design features as a channel to enhance work engagement.

- Transform work processes, physical design, and hospital culture. For instance, reducing the 'hunting and gathering' time by re-organizing supplies from central locations to fit more convenient stock locations closer to the patients' rooms, or introducing a 'peace and quiet time' for an hour during each nursing shift to promote a more calming working environment. (Hassmiller \& Cozine, 2006)

\section{Overview of sectoral policy interventions}

Overall, to mitigate the negative consequences of skill shortages in the three focus sectors it is relevant to adopt a dual approach. First, within the single firms: more attention to workforce planning and human resource development, together with improving the 
working conditions to not only retain existing staff but also attract new talent, even reaching segments that are closely related to the required field of work. Second, within the larger industry-wide or national context: more coordinated funding used strategically to support the establishment of new institutions, new programmes or multi-stakeholder initiatives. Table 19 provides a comprehensive overview of possible interventions at the sectoral level.

Table 19: Main recommendations and specific actions to address the skills shortages at the sectoral level

\begin{tabular}{|c|c|}
\hline Main Recommendations & Specific Actions \\
\hline \multirow{4}{*}{$\begin{array}{l}\text { Reintegration of the untapped / } \\
\text { inactive labour force (un- } \\
\text { employed, unskilled young } \\
\text { people, older craftsmen, etc.) }\end{array}$} & Provision of incentives for the reintegration of the inactive workforce \\
\hline & Provision of incentives for the exploitation of the untapped workforce \\
\hline & $\begin{array}{l}\text { Set of actions for connecting the inactive human resources to "green } \\
\text { professions" and "green jobs" }\end{array}$ \\
\hline & $\begin{array}{l}\text { Set of actions for stimulating the mobility of technicians/workers (in other EU } \\
\text { countries, for instance) }\end{array}$ \\
\hline \multirow{2}{*}{$\begin{array}{l}\text { Updating of the relevant } \\
\text { occupational profiles and } \\
\text { introduction of new ones (e.g. } \\
\text { as for assemblers/installers of } \\
\text { aluminum frames) }\end{array}$} & $\begin{array}{l}\text { Updating of methodology and of the existing occupational profiles in the } \\
\text { sector, to address the skill gaps, regarding RES and EE/ES applications in } \\
\text { buildings, in cooperation with the involved social bodies. }\end{array}$ \\
\hline & $\begin{array}{l}\text { Introduction of new occupational profiles (for the professions that are not } \\
\text { covered by the current ones) in cooperation with stakeholders and } \\
\text { representatives of each sector. }\end{array}$ \\
\hline \multirow{8}{*}{$\begin{array}{l}\text { Configuration of appropriate } \\
\text { CVET programmes, available } \\
\text { to the labour force in the } \\
\text { specific sector }\end{array}$} & Revision / updating of existing vocational training programmes \\
\hline & $\begin{array}{l}\text { Designing of a common framework to train technicians/workers per sector on } \\
\text { RES and EE issues }\end{array}$ \\
\hline & Development of specialised training programmes for each relevant profession \\
\hline & $\begin{array}{l}\text { Establishment of the appropriate laboratory facilities for the practical training } \\
\text { of the trainees }\end{array}$ \\
\hline & Introduction of flexible training methods (i.e. distance learning) \\
\hline & $\begin{array}{l}\text { Development of examination topics databases to evaluate the acquisition of } \\
\text { the newly proposed skills }\end{array}$ \\
\hline & $\begin{array}{l}\text { Elaboration of a basic programme (curriculum) on Energy Efficiency for all } \\
\text { employees in the construction sector (cross craft training - horizontal action) }\end{array}$ \\
\hline & $\begin{array}{l}\text { Introduction of the special thematic unit "Integrated interventions in buildings" } \\
\text { (horizontal action) }\end{array}$ \\
\hline \multirow{2}{*}{$\begin{array}{l}\text { Introduction of quality } \\
\text { assurance mechanisms with } \\
\text { regard to the training }\end{array}$} & Accreditation of training programmes \\
\hline & $\begin{array}{l}\text { Accreditation of the training and examination providers (for both the } \\
\text { theoretical and the practical part of the training) }\end{array}$ \\
\hline
\end{tabular}




\begin{tabular}{|c|c|}
\hline \multirow{3}{*}{$\begin{array}{l}\text { processes and qualifications } \\
\text { certification }\end{array}$} & Strengthening of the monitoring mechanisms of training providers \\
\hline & $\begin{array}{l}\text { Establishment of a record registering the accredited training bodies and } \\
\text { certified trainers }\end{array}$ \\
\hline & $\begin{array}{l}\text { Updating of the criteria for the registration in the registry of certified trainers, } \\
\text { per professional group, and establishment of a mechanism of continuous } \\
\text { training based on the technological developments }\end{array}$ \\
\hline \multirow{3}{*}{$\begin{array}{l}\text { Development of a } \\
\text { mechanism/framework to } \\
\text { ensure the required number of } \\
\text { trainers (pool of trainers) }\end{array}$} & $\begin{array}{l}\text { Development of training programmes for trainers regarding the new required } \\
\text { skills }\end{array}$ \\
\hline & $\begin{array}{l}\text { Exploitation of experienced technicians as trainers/instructors, especially in } \\
\text { the practical part of the training programmes }\end{array}$ \\
\hline & $\begin{array}{l}\text { Development of a mechanism to continuously educate the trainers on the } \\
\text { advanced technologies }\end{array}$ \\
\hline \multirow{5}{*}{$\begin{array}{l}\text { Upgrading of the institutional } \\
\text { framework over the cycle: } \\
\text { Training - Certification - } \\
\text { Regulation of the professions } \\
\text { and of the professional } \\
\text { qualifications }\end{array}$} & $\begin{array}{l}\text { Routing of arrangements, relating to training and certification issues, to ensure } \\
\text { the implementation of the Roadmap }\end{array}$ \\
\hline & Accreditation of occupational profiles by the competent institution \\
\hline & Development of an indicators system (ECTS) related to vocational training \\
\hline & $\begin{array}{l}\text { Routing of regulations, relating to the professional rights, to ensure the } \\
\text { implementation of the Roadmap }\end{array}$ \\
\hline & $\begin{array}{l}\text { Creation of a Committee for ensuring the quality and controlling the up } \\
\text { keeping of the quality characteristics of professional job, as determined by the } \\
\text { occupational profiles per profession, with responsibilities to recall the } \\
\text { certification and determine procedures for the updating of certification }\end{array}$ \\
\hline \multirow{2}{*}{$\begin{array}{l}\text { Development of a monitoring } \\
\text { mechanism to control and } \\
\text { retroact over the } \\
\text { implementation processes of } \\
\text { the proposed actions. }\end{array}$} & $\begin{array}{l}\text { Establishment of an appropriate mechanism in each involved Ministry to } \\
\text { monitor the implementation progress of the Roadmap }\end{array}$ \\
\hline & $\begin{array}{l}\text { Composition of an "Observatory" for the systematic monitoring of the new } \\
\text { needs for skills enhancement and/or acquisition of new, in matters of green } \\
\text { technologies }\end{array}$ \\
\hline \multirow{3}{*}{$\begin{array}{l}\text { Development and application } \\
\text { of the appropriate tools for the } \\
\text { implementation of the } \\
\text { proposed action plans }\end{array}$} & $\begin{array}{l}\text { Provision of incentives to employees in the sector, for participating in training } \\
\text { programmes related to green technologies }\end{array}$ \\
\hline & $\begin{array}{l}\text { Development of training programmes, funded by relevant chambers, unions } \\
\text { and vocational federations }\end{array}$ \\
\hline & $\begin{array}{l}\text { Integration of priority actions for the training and certification of qualifications, } \\
\text { and the support of employment of technicians/workers who acquire the } \\
\text { necessary skills, in the National Strategic Reference Framework (NSRF) } \\
\text { funds }\end{array}$ \\
\hline \multirow{3}{*}{$\begin{array}{l}\text { Dissemination, acceptance } \\
\text { and promotion of the scope, } \\
\text { activities and outcomes of the } \\
\text { National Qualification } \\
\text { Roadmap }\end{array}$} & $\begin{array}{l}\text { Informative actions on the advantages of the renovation interventions, aiming } \\
\text { at increasing the energy efficiency of residential buildings and in the private } \\
\text { sector }\end{array}$ \\
\hline & $\begin{array}{l}\text { Establishment of telephone lines for the provision of information and } \\
\text { assistance to the interested workers/technicians }\end{array}$ \\
\hline & $\begin{array}{l}\text { Development of a web application aiding at the identification of the essential } \\
\text { vocational skills per profession and of the appropriate accredited educational } \\
\text { programmes and structures }\end{array}$ \\
\hline
\end{tabular}




\begin{tabular}{|l|l|}
\hline $\begin{array}{l}\text { Enhancement of the } \\
\text { attractiveness and image of } \\
\text { the professions in the } \\
\text { construction sector }\end{array}$ & $\begin{array}{l}\text { Provide funding for large scale marketing campaigns and deliver targeted } \\
\text { grants to initiatives aimed at elevating the reputation of specific neglected } \\
\text { professional figures. }\end{array}$ \\
\hline $\begin{array}{l}\text { Fighting the black (uninsured) } \\
\text { employment }\end{array}$ & Tighten regulations against black uninsured employment and contracts \\
\hline $\begin{array}{l}\text { Provision of incentives to } \\
\text { encourage skilled workers stay } \\
\text { in the sector }\end{array}$ & $\begin{array}{l}\text { Provide targeted public subsidies to close the training gap and allow up-to- } \\
\text { date upskilling of workforce, especially in small companies. }\end{array}$ \\
\hline $\begin{array}{l}\text { Strengthening of the basic } \\
\text { Initial Vocational Education } \\
\text { and Training (IVET) of the } \\
\text { labour force in the specific } \\
\text { sectors of interest }\end{array}$ & $\begin{array}{l}\text { Experiment with the introduction of new courses, new grants, and public- } \\
\text { private cooperation schemes to enable a structured and continuous school- } \\
\text { to-work transition }\end{array}$ \\
\hline
\end{tabular}

Source: Retrieved and readapted from Doukas et al. (2016, p. 1003)

\section{Sub-question 5: Have other possible solutions been mentioned for the identified shortages in the middle segment of the Dutch labour market? If so, which?}

\section{General findings on bottleneck solutions}

- Strategies to cope with skills shortages and to overcome staffing bottlenecks require both comprehensive policy adjustments at the national level and targeted HR policies within firms.

- At the national level, various successful approaches have been taken to better match labour supply and demand in order to encourage people to study and work in specific areas with obvious shortages, such as STEM, ICT and R\&D.

- There is ample evidence that tailored approaches to human resource management and development have helped to marginalise the negative effects of skill shortages.

- The use of different recruitment channels (such as employment agencies and other intermediaries, cross-border postings) can also be helpful in filling vacancies.

- On the demand side: Compensation, recruitment parameters and job structuring are components of a skills gap strategy.

- On the supply side: Strategies aimed at offering new training courses or designing new training programmes, and strategies that reduce institutional barriers by introducing more efficient education, training and recruitment arrangements.

- It is important to give workers a T-shape set of necessary skills to move easily from one speciality to another.

- It should be noted that these strategies are usually not specific to the middle segment of the labour market, apart from measures that can be taken to improve the vocational training and education (VET) system and promote the recruitment of (VET) apprentices.

\section{Findings for the three focus sectors to tackle staffing bottlenecks}

- Metal sector

- In-house training for a T-shaped skill set

- Advancing human resource strategies

- Tap into disadvantaged labour segments

- Intensify cooperation and staff exchange with education institutes

- Strengthen the capacity of Public-Private Partnerships 
- Targeted training subsidies to small enterprises

- Following the trend of automatisation: Adapting to technological change

- Energy transition sector (examples from three subsectors)

$\circ$ Wind energy industry

- Promotion of shorter and flexible vocational training courses

- Promotion of collaboration between industry and academics

- Encouraging more industry input into academic courses in the relevant discipline

- Harmonisation of VET in the European context

- A well-planned national education and training strategy

- Set up investment programmes together with other employers, such as dual education systems

- Transnational networks may allow the acceptance of qualifications issued by institutions abroad to facilitate international mobility

- Technical installation (TI) industry

- Recruitment of staff from outside the TI industry is seen as an opportunity for employers

- Development of an Associate Degree programme

- Sustainable construction industry

- Provision of tailored training programs

- Improvement of HR strategies to guarantee long-term employment prospects

- Use of tailored governmental subsidies

- Stronger public-private partnerships

- Healthcare sector

- Embracement of new technologies

- Creating a new mid-professional role

- Adequate rewards

- Transforming the hospital work environment

- Transform work processes, physical design, and hospital culture

General opportunities for sectoral policy interventions are based on a dual approach

1. Within single firms: More attention to workforce planning and human resource development, together with improving the working conditions to not only retain existing staff but also attract new talent, even reaching segments that are closely related to the required field of work.

2. Within the larger industry-wide or national context: More coordinated funding used strategically to support the establishment of new institutions, new programmes or multi-stakeholder initiatives. 


\section{Conclusions and directions for further research}

This study reviews the literature regarding the possibilities and limitations of filling existing shortages in the middle segment of the Dutch labour market by means of (selective) labour migration. The purpose of the study is to gain more insight into the (im)possibilities of focusing migration policy more on the middle segment of the Dutch labour market to alleviate shortages of medium-skilled workers. In this study, the 'middle segment' refers to the part of the labour market for workers with a three or four-year intermediate vocational education (mbo 4-level).

In this concluding section we ask ourselves How do the opportunities and limitations/ possibilities and impossibilities of the instruments relate to each other, especially for the possible role of labour migration policy? This refers to sub-question 6 of the introductory section of this report. The answer to the sub-question is based on the previous analyses, the opportunities for targeted migration and alternative labour market policies as well as the barriers and limitations that are relevant to carry out these policies. Therefore the answer to this sub-question brings together the preceding sections on both migration policies and labour market policies as different ways to tackle staffing bottlenecks in the middle segment of the Dutch labour market. Next to answering this sub-question, we also provide some directions for further research, based on what we have found or could not find to answer the six subquestions listed in Section 1 of the report.

Although the evidence is scare, we have found (see European Commission, 2020a) that there is hardly any oversupply in EEA+ countries for the shortage occupations in the Netherlands, including those related to the three focus sectors. Hence, it is probably very difficult to recruit from the priority supply. Skills shortages requiring personal intervention (e.g. healthcare related) as well as technical (STEM expertise) skills shortages are widespread and severe in EEA+ countries. Health professions figured in 2019 and 2020 more prominently than in previous years; nurses even ranked first among occupations with a shortage. We can conclude that it may be necessary to attract workers from third countries to fill the vacancies for these occupations.

Due to the aging population in EEA+ countries, the supply of potential workers should be sought for outside these areas. There is a potential supply in Africa, but this is a relatively 'short-term' solution. Facilitating more options for the free movement of current TCNs in EEA+ countries could have a positive impact on their labour demand and supply. European and Dutch migration policies focus on the highly skilled, which is why migration of the mediumskilled is more difficult to realise, even if there is a supply outside the EEA+ countries and even if people are willing to migrate. Limited transferability of foreign degrees and qualifications may contribute to underemployment of many migrants in the Netherlands.

While migration cannot be the only solution to filling skills shortages, migration can be one of the most efficient ways to address skills shortages. In the Netherlands, there is no legal instrument available that targets the medium-skilled specifically. As a result mediumskilled migration from third countries is only possible through various rather restrictive channels. Migration is very much dependent on employers, who often prefer alternative solutions to recruiting migrants. This may be due to prejudices, stereotypes and lack of 
transparency on diplomas and competences of migrants, but also due to the lack of both general (social and language) skills as well as specific vocational skills. Furthemore, the procedures for the recognition of foreign qualifications are expensive and lengthy, which is in particular an obstacle for the healthcare sector. It could be possible to improve the free movement of TCNs through the expansion of the Single Permit Directive. There are furthermore possibilities to introduce a migration policy specifically aimed at the medium-skilled level, like the Skilled Immigration Act in Germany. Although there are already some indications that this has been successful in fostering a higher influx of skilled migrants to Germany, the recognition requirement could be a major hurdle. The Swedish system can also be a good example for the Netherlands. It has proven to be effective, although there are still some shortcomings, such as the abuse of migrant workers. To keep labour migrants in the Netherlands, it is also important that they integrate into Dutch society.

Strategies to overcome skills shortages and workforce bottlenecks can be implemented through comprehensive policy adjustments at the national level and targeted human resource policies within companies. At the national level, various successful approaches have been taken to better match labour supply and demand in order to encourage people to study and work in specific areas with obvious shortages, such as STEM, ICT and R\&D. There is ample evidence that tailored approaches to HR management and development have helped to marginalise the negative effects of skill shortages. The use of different recruitment channels (such as employment agencies and other intermediaries, cross-border postings) can also be helpful in filling vacancies. Although they can be successful, it should be noted that all national strategies and HR policies require a lot of effort and huge investments. They are usually not specific to the middle segment of the labour market, and even not limited to the national workforce, but can also be applied to migrant workers or workers with a migrant background. On the demand side, wage compensation, recruitment parameters and job structuring are important components of a skills gap strategy. On the supply side, strategies that may reduce the skills gap are aimed at offering new training courses or designing new training programmes, and at reducing institutional barriers by the introduction of more efficient education, training and recruitment arrangements.

Apart from the fact that firms need to pay more attention to workforce planning and HR development in order to attract new talent, a more flexible migration policy, focused on the medium-skilled, could support firms in addressing labour market shortages. Firms cannot easily hire workers from abroad if national or European regulations make it difficult for labour migrants to work in the shortage occupations in the Netherlands. Particularly for migrants from third countries who do not belong to the group of highly skilled knowledge workers and who intend to move to the Netherlands, it may take a long time before they obtain the required residence or work permit, have their diplomas or certificates recognised or assessed, or have their prior learning validated. Employers may see labour migration as one of the tools to recruit people from abroad, and due to administrative barriers they often prefer to recruit workers from the Netherlands. Making it easier for migrants to apply for work permits and have their diplomas or competences recognised could change this. Another possibility is the introduction of sectoral migration policies and the creation of mobility partnerships (including vocational training policies) to better match supply and demand. However, one may question whether even more migration schemes should be added to the 
Dutch labour migration system, as this would lead to even more fragmentation, and perhaps less equity between different migrant groups.

\section{Directions for further research}

The literature review shows that there is hardly any literature focusing on the migration of medium-skilled (mbo 4-level) workers employed in the three focus sectors to the Netherlands specifically. If information about migration of medium-skilled workers is mentioned at all, it is rather general or superficial. Therefore, we conclude that the knowledge about the opportunities and limitations of filling labour shortages through migration in the middle segment of the labour market is very limited, especially when looking at the three focus sectors of this study.

We suspect that the gap in the literature can partly be ascribed to a lack of data. Quantitative research on migration is often based on national register data, which often does not include information on migrants' educational level achieved abroad. This is also the case for Dutch register data available through the Centraal Bureau voor de Statistiek (CBS). The ACVZ (2019) also criticised the lack of data in understanding labour migration to the Netherlands.

Another reason for this gap is that the target group for the analyses in this study is rather narrow. Not only does a sector of industry cover only a small part of the labour market, but within the focus sectors we have also tried to delineate the sub-group of mbo 4-level workers in certain occupations. Therefore, it is difficult to analyse the job opportunities and migration constraints of a relatively small subgroup of medium-skilled workers, i.e. those who graduated at the highest level of secondary vocational education (mbo 4-level). Another complicating factor is that the energy transition sector is not a well-defined industry within international and Dutch statistical classifications. Energy transition takes place in the energy sector itself in subsectors such as wind and solar industries, but also in the construction and installation sectors. However, by no means all economic activities within these sectors can be considered energy transition activities. Moreover, the key occupations within the focus sectors are often also found in other industries. This applies in particular to the metal and energy transition sectors, but hardly at all to the care sector. For the latter sector, the analyses are relatively easy because the most important shortages on the labour market for medium-skilled workers on mbo level-4 relate to the occupation of nurses. For this occupation, a relatively large amount of information is available in databases and empirical studies.

For further research, it might be promising to focus on certain key occupations and to analyse more thoroughly the skill requirements, opportunities and constraints for migrant workers to enter these occupations. Apart from some quantitative statistics, one would probably have to rely heavily on interviews with industry experts to obtain a variety of information. In addition, it may be worthwhile to investigate the possibilities of recruiting medium-skilled migrants through intermediary and temporary work agencies. More specific information on the trends and dynamics of posted work to the Netherlands is scarce. We could not identify any literature that covers the posting of TCNs working in the three focus sectors. Again, more qualitative rather than quantitative methods may be of great help. Another promising direction may be research to better understand the employer perspective. It would be useful to conduct a survey among 
employers (including SMEs) in the Netherlands to better understand their strategies to fill skills shortages including through migration. Finally, future research could also establish the effectiveness of the new skilled worker migration policies introduced specifically for mediumskilled workers in Germany.

\section{Effects of COVID-19 on the findings}

The COVID-19 crisis and the measures to combat the virus do negatively impact the demand as well as the supply side of the labour market. The impact of the crisis as well as the management of the crisis (epidemiological, economic) on the middle segment of the labour market has been investigated to some extent in this report, and definitely differ greatly between and within sectors of industry (UWV, 2021b). Although some industries have suffered from forced closures (e.g. restaurants and bars) and others have benefited (e.g. some ICT firms and delivery services), there was a general decline in employment and a rise in unemployment. In response to lower labour demand and international travel restrictions, labour migration to the Netherlands has declined. Economic growth, labour demand and migration are expected to increase again after the corona crisis (CBS, 2020; CPB, 2021). The higher mortality rate and lower immigration have led to a slowdown in population growth in 2020 , but it is expected to pick up again in the following years.

According to the UWV, there are still occupations with hard-to-fill vacancies, albeit fewer than a year ago. The occupations that have disappeared from the list of shortage occupations are mainly to be found in hospitality, sales, cleaning, security and transport and logistics. But also before the COVID-19 crisis, a limited number of occupations had poor or reasonable job opportunities. Since the COVID-19 crisis, these occupations still do not offer good opportunities. Some of these occupations have proven vulnerable to digitalisation and automation. In other cases, the labour demand still exceeds the labour supply. Particularly in the healthcare sector the gap has widened. The UWV data on shortage occupations that we have presented in this study are as up to date as possible and therefore, with some delay, take into account the COVID-19 crisis. Furthermore, we have argued that the quality of the directions in the medium-term labour market forecast data that we have used from ROA's Labour Market Information System (AIS) has probably not suffered much from the COVID-19 crisis. For the necessity we have used this data, namely to select the shortage occupations in Section 3 of our report, the quality of the data is probably good enough. For other statistics we have used, for example on migration, the COVID-19 crisis has certainly had a major impact on the decline in the number of immigrants, although this is not as important for our analyses of labour migration regulations and policies.

Sub-question 6: How do the opportunities and limitations/ possibilities and impossibilities of the instruments relate to each other, especially for the possible role of labour migration policy?

Answer:

- Although available data sources at European level are scarce, there seems to be hardly any oversupply in the EEA+ countries for the shortage occupations in the Netherlands, including those related to the three focus sectors. Therefore it is probably very difficult to recruit from the priority supply. We can conclude that it may be 
necessary to attract workers from third countries to fill the vacancies for these occupations.

- Although migration cannot be the only solution to filling skills shortages, migration can be one of the most efficient ways to address skills shortages.

- Medium-skilled migration from third countries is only possible through various rather restrictive channels.

- Migration is very much dependent on employers, who often prefer alternative solutions to recruiting migrants. This may be due to prejudices, stereotypes and lack of transparency on diplomas and competences of migrants, but also due to the lack of both general (social and language) skills as well as specific vocational skills. Furthermore, the procedures for the recognition of foreign qualifications are expensive and lengthy, which is in particular an obstacle for the healthcare sector.

- Alternative strategies to cope with skills shortages and to overcome staffing bottlenecks require both comprehensive policy adjustments at the national level and targeted HR policies within firms. Although they can be successful, it should be noted that all national strategies and HR policies require a lot of effort and huge investments.

- Employers may see labour migration as one of the tools to recruit people from abroad, and due to administrative barriers they often prefer to recruit workers from the Netherlands.

- Apart from the fact that firms could pay more attention to workforce planning and HR development in order to attract new talent, a more flexible migration policy, focused on the medium-skilled, could support firms in addressing labour market shortages. 


\section{References}

Abdel-Wahab, M. (2012). Rethinking apprenticeship training in the British construction industry. Journal of Vocational Education \& Training, 64(2), 145-154.

https://doi.org/10.1080/13636820.2011.622450

ACVZ. (2019). Legal Channels for Migrant Workers. An exploratory study. 73.

ACVZ. (2021). Van asielzoeker naar zorgverlener. Arbeidsdeelname van asielmigranten in de zorgsector.

https://www.adviescommissievoorvreemdelingenzaken.nl/publicaties/publicaties/2021/0 $\underline{5 / 11 / v a n-a s i e l z o e k e r-n a a r-z o r g v e r l e n e r}$

Aithal, A., \& Aithal, P. S. (2017). Task-Shifting-An Alternative Survival Strategy for Health-Care Organizations. International Journal of Scientific Research and Modern Education (IJSRME), 2(2), 34-48.

Aksakal, M., \& Reslow, N. (2019). (Un)intended Consequences in High- Skilled Migrants" Integration and Inequali- ties: A comparison of Policy in Germany and the Netherlands. Working Papers, 25.

Akyazi, T., Goti, A., Oyarbide-Zubillaga, A., Alberdi, E., Carballedo, R., Ibeas, R., \& Garcia-Bringas, P. (2020). Skills Requirements for the European Machine Tool Sector Emerging from Its Digitalization. Metals, 10(12), 1665.

https://doi.org/10.3390/met10121665

Aldersgate Group. (2009). Mind the Gap: Skills for the Transition to a Low Carbon Economy. Aldersgate Group.

Aliagha, G. U., Goh, A. P. T., Abdullah, M. N., Jaafar, N. M., \& Eluwa, S. E. (2014). Investigating Skill Gaps in Green Building Skills for Energy Efficiency. Advanced Materials Research, 1073-1076, 1282-1287.

https://doi.org/10.4028/www.scientific.net/AMR.1073-1076.1282

Amelina, A. (2017). Transnationalizing Inequalities in Europe. Sociocultural Boundaries, Assemblages and Regimes of Intersection. Routledge.

Antonazzo, L., Weinel, M., \& Stroud, D. (2020). Blueprint "New Skills Agenda Steel": Industry-driven sustainable European Steel Skills Agenda and Strategy (ESSA). Analysis of cross-European VET frameworks and standards for sector skills recognition. European Steel Skills Agenda. 
Arnholtz, J., \& Andersen, S. K. (2018). Extra-Institutional Changes under Pressure from Posting. British Journal of Industrial Relations, 52(2), 395-417.

Ashton, A. S. (2018). How human resources management best practice influence employee satisfaction and job retention in the Thai hotel industry. Journal of Human Resources in Hospitality \& Tourism, 17(2), 175-199.

https://doi.org/10.1080/15332845.2017.1340759

Attström, K., Niedlich, S., Sandvliet, K., Kuhn, M., Beavor, E., \& Urth, H. (2014). Mapping and Analysing Bottleneck Vacancies in EU Labour Markets. Overview report. Final. European Commission, 122.

Avontuur, S., \& Otten, C. (2021). Migratie en de zorgsector. Cijfers over de arbeidsmarkt in de zorgsector en de arbeidsdeelname van migranten.

https://www.adviescommissievoorvreemdelingenzaken.nl/publicaties/publicaties/2021/0 $\underline{5 / 11 / \text { cijferoverzicht-migratie-en-de-zorgsector }}$

Baas, M. (2017). The mobile middle: Indian skilled migrants in Singapore and the 'middling' space between migration categories. Transitions: Journal of Transient Migration, 1(1), 47-63. https://doi.org/10.1386/titm.1.1.47 1

Bagavos, C. (2019). The importance of foreign migration for shifts in the size of the labour force of European countries: Methodological insights and contemporary evidence from SIRIUS and from selected Non-SIRIUS countries. SIRIUS, Working Paper No.2(D 8.5).

Bakens, J., Bijlsma, I., Dijksman, S., Fouarge, D., \& de Lombaerde, G. (2019). De arbeidsmarkt naar opleiding en beroep tot 2024. ROA. ROA Reports No. 007 https://doi.org/10.26481/umarep.2019007

Bakens, J., Fouarge, D., \& Rogier, G. (2020). Beroepen met complexe vaardigheden minst geraakt door de coronacrisis. ESB, 105(4789), 410-413.

https://cris.maastrichtuniversity.nl/en/publications/beroepen-met-complexevaardigheden-minst-geraakt-door-de-coronacr

Barile, S., Franco, G., Nota, G., \& Saviano, M. (2012). Structure and Dynamics of a "TShaped" Knowledge: From Individuals to Cooperating Communities of Practice. Service Science, 4(2), 161-180. https://doi.org/10.1287/serv.1120.0014

Barrett, S., Hanna, K., \& Ullah, S. (2014). Skills to build: LCCI/KPMG construction skills index. London Chamber of Commerce and Industry.

Barslund, M., \& Busse, M. (2014). Too much or too little labour mobility?: State of play and policy issues. 
Barslund, M., \& Busse, M. (2016). Labour Mobility in the EU: Addressing Challenges and Ensuring 'Fair Mobility'.

Beblavý, M., Mýtna Kureková, L., \& Haita, C. (2016). The surprisingly exclusive nature of medium- and low-skilled jobs: Evidence from a Slovak job portal. Personnel Review, 45(2), 255-273. https://doi.org/10.1108/PR-12-2014-0276

Beech, Bottery, Evans, Gershlick, Charlesworth, Hemmings, McKenna, Palmer, Murray, Imison, \& Kahtan. (2019). Closing the gap: Key areas for action on the health and care workforce. Closing the Gap, 165.

Benton, M., \& Petrovic, M. (2013). How free is free movement? Dynamics and drivers of mobility within the European Union.https://www.migrationpolicy.org/pubs/MPIEuropeFreeMovement-Drivers.pdf

Benton, M., Sumption, M., Alsvik, K., Fratzke, S., Kuptsch, C., \& Papademetriou, D. G. (2014). Aiming Higher: Policies to Get Immigrants into Middle-Skilled Work in Europe. MPI-ILO, 39.

Berenschot, van B. (2009). Immigratie Van Zorgpersonnel, Van sluitpost van arbeidsmarkt-beleid naar oplossingen voor een modern migratiebeleid voor de zorg. (Immigration Care Staff: Final item of Labour Policy Solutions for a modern Migration for Care). Ministry of Health, Welfare and Sports. Netherlands.

Berg, M. van den \& Rijksinstituut voor Volksgezondheid en Milieu (Bilthoven). (2015). Dutch Health Care Performance Report 2014. National Institute for Public Health and the Environment (RIVM).

Berge, W. van den, Vlasblom, J. D., Ebregt, J., Putman, L., Zweerink, J., \& Graaf-Zijl, M. de. (2018). Verdringing op de arbeidsmarkt: Beschrijving en beleving. Centraal Planbureau / Sociaal en Cultureel Planbureau.

Bevan, W., Lu, S.-L., \& Sexton, M. (2020). Skills required to deliver energy efficient school retrofit buildings. Engineering, Construction and Architectural Management, 27(10), 3051-3073. https://doi.org/10.1108/ECAM-03-2019-0126

Blay, N., \& Roche, M. A. (2020). A systematic review of activities undertaken by the unregulated Nursing Assistant. Journal of Advanced Nursing, 76(7), 1538-1551.

https://doi.org/10.1111/jan.14354

Bloch, A., \& McKay, S. (2015). Employment, Social Networks and Undocumented Migrants: The Employer Perspective. Sociology, 49(1), 38-55.

https://doi.org/10.1177/0038038514532039 
Boockmann, B. (2015). The effects of wage subsidies for older workers. IZA World of Labor. https://doi.org/10.15185/izawol.189

Boswell, C., Stiller, S., \& Straubhaar, T. (2004). Forecasting Labour and Skills

Shortages: How Can Projections Better Inform Labour Migration Policies? 54.

Branca, T. A., Fornai, B., Colla, V., Murri, M. M., Streppa, E., \& Schröder, A. J. (2020).

The Challenge of Digitalization in the Steel Sector. Metals, 10(2), 288.

https://doi.org/10.3390/met10020288

Brunello, G., \& Wruuck, P. (2019). Skill Shortages and Skill Mismatch in Europe: A

Review of the Literature. IZA World of Labor, N.12346, 35.

Bruyneel, L., Li, B., Aiken, L., Lesaffre, E., Van den Heede, K., \& Sermeus, W. (2013). A multi-country perspective on nurses' tasks below their skill level: Reports from domestically trained nurses and foreign trained nurses from developing countries. International Journal of Nursing Studies, 50(2), 202-209.

https://doi.org/10.1016/j.ijnurstu.2012.06.013

Brydon, R., \& Dachis, B. (2013). Access Denied: The Effect of Apprenticeship Restrictions in Skilled Trades. SSRN Electronic Journal.

https://doi.org/10.2139/ssrn.2303826

Bundesagentur für Arbeit. (n.d.). Projekt Triple Win. Arbeitsagentur.De.

https://www.arbeitsagentur.de/vor-ort/zav/Triple-Win-Pflegekraefte

Bundesagentur für Arbeit, \& GIZ. (2013). Placement of qualified nurses from the Philippines in Germany.

https://www.poea.gov.ph/TWP/files/Triple\%20Win\%20Philipinen.pdf

Bundesagentur für Arbeit, \& GIZ. (2019). Projekt Triple Win. Vermittlung von

Pflegekräften aus dem Ausland. Informationsbroschüre für Arbeitgeber.

https://www.giz.de/en/downloads/Broschüre Triple Win Informationen.pdf

Cairncross, G., \& Kelly, S. (2008). Human resource development and 'casualisation' in hotels and resorts in Eastern Australia: Getting the best to the customer? Journal of Management and Organization, 14, 367-385.

Calleman, C. (2015). "The Most Open System Among OECD Countries": Swedish regulation of labour migration. Nordic Journal of Migration Research, 5(1), 28.

https://doi.org/10.1515/njmr-2015-0001 
Cameron, L., \& van der Zwaan, B. (2015). Employment factors for wind and solar energy technologies: A literature review. Renewable and Sustainable Energy Reviews, 45, 160-172. https://doi.org/10.1016/j.rser.2015.01.001

Cappelli, P. (2012). Why good people can't get jobs: The skills gap and what companies can do about it. Wharton Digital Press.

Capuano, S., \& Migali, S. (2017). The migration of professionals within the EU: Any barriers left?

Caro, E., Berntsen, L., Lillie, N., \& Wagner, I. (2015). Posted Migration and Segregation in the European Construction Sector. Journal of Ethnic and Migration Studies, 41(10), 1600-1620. https://doi.org/10.1080/1369183X.2015.1015406

Castles, S., de Haas, H., \& Miller, M. J. (2014). The Age of Migration: International population movements in the modern world (5th ed.). Palgrave MacMillan.

CBGV. (2019). Jaarverslag 2019 Commissie Buitenslands Gediplomeerden Volksgezondheid.

CBS. (2019a). Nearly 180 thousand jobs filled by Polish workers, 4 April 2019.

https://www.cbs.nl/en-gb/news/2019/14/nearly-180-thousand-jobs-filled-by-polishworkers

CBS. (2019b). Trends in the Netherlands. 2019. CBS - Statistics Netherlands.

CBS. (2020). Forecast: Population growth unabated in the next 50 years.

CBS. (2021). Werknemers geboren in buitenland; wel/niet ingezeten, persoonskenmerken.

https://opendata.cbs.nl/\#/CBS/nl/dataset/84750NED/table?dl=49D5C

CPB. (2020). Actualisatie Verkenning middellange termijn 2022-2025 (maart 2021) https://www.cpb.nl/actualisatie-middellangetermijnverkenning-2022-2025-maart-2021

CEDEFOP. (2016a). Metal \& machinery workers: Skills opportunities and challenges [Skills Intelligence]. Skill Panorama.

https://skillspanorama.cedefop.europa.eu/en/analytical highlights/metal-machineryworkers-skills-opportunities-and-challenges-2016

CEDEFOP. (2016b). Skill shortage and surplus occupations in Europe: Cedefop insights into which occupations are in high demand - and why. Publications Office.

https://data.europa.eu/doi/10.2801/05116 
CEDEFOP. (2020). Skills forecast 2020: Netherlands. CEDEFOP Skills Forecast, 14.

CIBG. (n.d.-a). BIG-register. BIG-Register. Retrieved 9 April 2021, from https://english.bigregister.nl/

CIBG. (n.d.-b). Certificate of competence. Certificate of Competence. Retrieved 9 April 2021, from https://english.bigregister.nl/foreign-diploma/procedures/certificate-ofcompetence

CIBG. (n.d.-c). Qualification older than five years. Qualification Older than Five Years. Retrieved 9 April 2012, from https://english.bigregister.n//foreigndiploma/procedures/direct-enrolment/qualification-older-than-five-years

CIBG. (n.d.-d). Recognition of professional qualifications. Recognition of Professional Qualifications. Retrieved 9 April 2012, from https://english.bigregister.n/foreigndiploma/procedures/recognition-professional-qualifications

Cillo, R. (2020). From Morocco and Tunisia to Belgium via Italy: Migration and posting of third country nationals. Ca' Foscari University.

https:/www.unive.it/pag/fileadmin/user upload/dipartiment/filosofia/doc/laboratori/laris/e venti/Con3Post - From Morocco and Tunisia to Belgium via Italy.pdf

Combes, J.-B., Elliott, R. F., \& Skåtun, D. (2018). Hospital staff shortage: The role of the competitiveness of pay of different groups of nursing staff on staff shortage. Applied Economics, 50(60), 6547-6552. https://doi.org/10.1080/00036846.2018.1490000

Coventry, T. H., Maslin-Prothero, S. E., \& Smith, G. (2015). Organizational impact of nurse supply and workload on nurses continuing professional development opportunities: An integrative review. Journal of Advanced Nursing, 71(12), 2715-2727. https://doi.org/10.1111/jan.12724

Cremers, J. (2016). Economic freedoms and labour standards in the European Union. Transfer: European Review of Labour and Research, 22(2), 149-162. https://oi.org/10.1177/1024258916635962

Cremers, J. (2018). Posting of workers in practice. INT-AR Paper 8. https://pure.uvt.nl/ws/portalfiles/portal/19948174/INT AR paper 8 English.pdf

Cremers, J., \& Dekker, R. (2018). Labour arbitrage on European labour markets: Free movement and the role of intermediaries. In Towards a decent labour market for low waged migrant workers (pp. 109-128). Amsterdam University Press.

https://pure.uvt.nl/ws/portalfiles/portal/28169031/Cremers Dekker boek C.Rijken.pdf 
Crouch, C. (2015). Labour Market Governance and the Creation of Outsiders: The Creation of Outsiders. British Journal of Industrial Relations, 53(1), 27-48.

https://doi.org/10.1111/bjir.12058

Cukut Krilić, S., Toplak, K., \& Vah Jevšnik, M. (2020). Posting of third country nationals: A comparative study. ZRC SAZU. https://www.euro.centre.org/downloads/detail/3930

Danaj, S., Geyer, L., Cukut Krilić, S., Toplak, K., \& Vah Jevšnik, M. (2020). From Bosnia and Herzegovina to Austria via Slovenia: Migration and posting of third country nationals in the EU. European Centre for Social Welfare Policy and Research and ZRC SAZU. https://www.researchgate.net/publication/342715849 From Bosnia and Herzegovina t o Austria via Slovenia migration and posting of third country nationals in the EU

Das, G. G., Marjit, S., \& Kar, M. (2020). The Impact of Immigration on Skills, Innovation and Wages: Education Matters more than where People Come from. Journal of Policy Modeling, 42(3), 557-582. https://doi.org/10.1016/i.jpolmod.2020.02.003

Davidson, C. I., Hendrickson, C. T., Matthews, H. S., Bridges, M. W., Allen, D. T., Murphy, C. F., Allenby, B. R., Crittenden, J. C., \& Austin, S. (2010). Preparing future engineers for challenges of the 21st century: Sustainable engineering. Journal of Cleaner Production, 18(7), 698-701. https://doi.org/10.1016/j.jclepro.2009.12.021

Davies, A., Bagust, P., \& Basquill, A. M. (2018). Modern Methods of Construction: A Forward-thinking Solution to the Housing Crisis?. RICS.

https://www.rics.org/globalassets/rics- website/media/news/news--opinion/modernmethods-of-construction-paper-rics.pdf

De Lange, T., \& Groenendijk, K. (2021). The EU's legal migration acquis: Patching up the patchwork.

De Lange, T., Oomes, N., Gons, N., \& Spanikova, V. (2019). Labour Migration and Labour Market Integration of Migrants in the Netherlands: Barriers and Opportunities. 62.

de Veer, A., den Ouden, D.-J., \& Francke, A. (2004). Experiences of foreign European nurses in The Netherlands. Health Policy, 68(1), 55-61.

https://doi.org/10.1016/j.healthpol.2003.08.006

De Wispelaere, F., De Smedt, L., \& Pacolet, J. (2019). Posting of workers: Report on A1 Portable Documents issued in 2018. HIVA-KU Leuven.

Della Torre, L., \& de Lange, T. (2017). The 'importance of staying put': Third country nationals' limited intra-EU mobility rights. Journal of Ethnic and Migration Studies, 44(9), 1409-1424. 
Dello lacono, C., Orfrao, G., \& Stanek, M. (2021). The changing nature of intraEuropean mobility of third country nationals. HIVA - Research Institute for Work and Society. https://hummingbird-h2020.eu/news/news-items/D3.1

Dijksman, S., Gerards, R., de Grip, A., Peeters, T., van Eldert, P., \& Veth, J. (2017). Arbeidsmarktmonitor Metalektro 2017. Maastricht University, 114.

Dittrich, P.-J., \& Spath, N. (2016). De-jure Freizügigkeit und de-facto Mobilität im EUbinnenmarkt (p. 22). Jacques Delors Institut. https://www.hertieschool.org/fileadmin/user upload/Arbeitskraeftemobilitaet-DittrichSpath-JDIBApril16.pdf

Doukas, H., Siskos, E., Psarras, J., Malamatenios, C., Tournaki, S., \& Tsoutsos, T. (2016). Qualification roadmap empowering the Greek building sector workforce in the field of energy. Renewable and Sustainable Energy Reviews, 65, 992-1004.

https://doi.org/10.1016/j.rser.2016.07.022

Downey, M. (2021). Partial automation and the technology-enabled deskilling of routine jobs. Labour Economics, 69, 101973. https://doi.org/10.1016/j.labeco.2021.101973

Drennan, V. M., Calestani, M., Ross, F., Saunders, M., \& West, P. (2018). Tackling the workforce crisis in district nursing: Can the Dutch Buurtzorg model offer a solution and a better patient experience? A mixed methods case study. BMJ Open, 8(6), e021931. https://doi.org/10.1136/bmjopen-2018-021931

Dromey, J., \& McNeil, C. (2017). Skills 2030: Why the adult skills system is failing to build an economy that works for everyone. The Progressive Policy ThinkTank (IPPR). https://www. ippr. org/files/publications/pdf/skills-2030 Feb2017. pdf.

Dubow, T., Roeder, S., Marchant, K., \& Siegel, M. (2019). Evidence on the determinants of migration in the EU.

https://ec.europa.eu/research/participants/documents/downloadPublic?documentlds=08 0166e5c69c7652\&appld=PPGMS

Duvekot, R. (2019). European inventory on validation of non-formal and informal learning 2018 update:

Netherlands.http://libserver.cedefop.europa.eu/vetelib/2019/european inventory validati on 2018 Netherlands.pdf

EASME. (2019). Blueprint for sectoral cooperation on skills: Towards an EU strategy addressing the skills needs of the steel sector: European vision on steel related skills of today and tomorrow. Publications Office. https://data.europa.eu/doi/10.2826/458269 
Echterhoff, V., Schelkle, P., \& Cassel, S. (2020). Attracting Talents to the Steel Industry. Recommendation Paper.

ECLAC, \& ILO. (2017). Employment Situation in Latin America and the Caribbean (No. 22).

Eindhovens Dagblad (2018). Stedin wil asielzoekers opleiden tot monteur. augustus.

Emilsson, H. (2014). Labour Migration in a Time of Crisis: Results of the New DemandDriven Labour Migration System in Sweden.

Emilsson, H., \& Irastorza, N. (2019). 30 percent lower income: A follow-up of the Swedish 2008 labour migration reform. MIM Working Paper Series 19: 1.

Emilsson, H., \& Irastorza, N. (2020). The Effects of the 2008 Labour-Migration Reform in Sweden: An Analysis of Income. GLO Discussion Paper, 680.

Eriksson, S., \& Rooth, D.-O. (2014). Do Employers Use Unemployment as a Sorting Criterion When Hiring? Evidence from a Field Experiment. American Economic Review, 104(3), 1014-1039. https://doi.org/10.1257/aer.104.3.1014

Ette, A., Heß, B., \& Sauer, L. (2016). Tackling Germany's Demographic Skills Shortage: Permanent Settlement Intentions of the Recent Wave of Labour Migrants from NonEuropean Countries. Journal of International Migration and Integration, 17(2), 429-448. https://doi.org/10.1007/s12134-015-0424-2

European Centre for the Development of Vocational Training (Ed.). (2018). Insights into skill shortages and skill mismatch: Learning from Cedefop's European skills and jobs survey. Publications Office of the European Union.

Treaty of the Functioning of the European Union, Art. 79, (1958).

European Commission. (2015). Determining labour shortages and the need for labour migration from third countries in the EU (EMN Focused Study).

https://ec.europa.eu/home-affairs/sites/default/files/what-wedo/networks/european migration network/reports/docs/emn-studies/emn-studies05a cyprus labour shortages final.pdf

European Commission. (2018). Integration of migrant women. European Website on Integration. https://ec.europa.eu/migrant-integration/feature/integration-of-migrantwomen

European Commission. (2019). Report of the High-Level Expert Group on the Impact of the Digital Transformation on EU Labor Markets. European Commission. 
European Commission. (2020a). Analysis of shortage and surplus occupations 2020.

(Directorate General for Employment, Social Affairs and Inclusion.). Publications Office. https://data.europa.eu/doi/10.2767/933528

European Commission. (2020b). Intra-EU Labour Mobility at a glance: Main findings of the 2019 Annual Report on intra-EU Labour Mobility.

https://ec.europa.eu/social/main.jsp?catld=738\&langld=en\&publd=8242\&furtherPubs=y es

European Commission. (2020c). European Construction Sector Observatory. Country Profile: Netherlands 2020. European Commission - Internal Market, Industry, Entrepreneurship and SMEs.

European Commission. (2021). The Atlas of Migration 2020.

European Commission. (n.d.). Regulated professions by country, with competent authorities. Regulated Professions by Country, with Competent Authorities.

https://ec.europa.eu/growth/tools-databases/regprof/index.cfm

Ezeh, A., Kissling, F., \& Singer, P. (2020). Why sub-Saharan Africa might exceed its projected population size by 2100.

Falkenstein-Smith, R., Milcarek, R., Garrett, M., \& Ahn, J. (2016). Exploring T-Shaped Professional Skill Development in Graduate Students in an Advanced Energy Systems Course. 2016 ASEE Annual Conference \& Exposition Proceedings, 26864.

https://doi.org/10.18260/p.26864

Fang, T. (2009). Workplace responses to vacancies and skill shortages in Canada. International Journal of Manpower, 30(4), 326-348.

https://doi.org/10.1108/01437720910973034

Farmer. (2016). The Farmer Review of the UK Construction Labour Model: 'Modernise or Die'. Casi Consultancy. http://www.cast-consultancy.com/wp-

content/uploads/2016/10/Farmer-Review-1.pdf

Fassio, C., Montobbio, F., \& Venturini, A. (2019). Skilled migration and innovation in European industries. Research Policy, 48(3), 706-718.

https://doi.org/10.1016/j.respol.2018.11.002

Federal Foreign Office. (2021, March 2). Germany opens labour market for skilled workers from non-EU countries. Germany Opens Labour Market for Skilled Workers from Non-EU Countries. https://www.auswaertiges-

amt.de/en/einreiseundaufenthalt/feg\#: :text=Germany\%20opens\%20labour\%20market 
\%20for\%20skilled\%20workers\%20from\%20non\%2D\%20EU\%20countries\&text=New\% 20rules\%20for\%20the \%20immigration\%20 of\%20skilled\%20workers\%20to\%20German y,come\%20to\%20work\%20in\%20Germany.

Federal Ministry Of The Interior Building And Community. (2021, February 26). The Skilled Immigration Act - one year on-Press release. The Skilled Immigration Act One Year On.

https:/www.bmi.bund.de/SharedDocs/pressemitteilungen/EN/2021/02/skilledimmigration-act.html

Felstead, A., Gallie, D., Green, F., \& Henseke, G. (2020). Getting the Measure of Employee- Driven Innovation and Its Workplace Correlates. British Journal of Industrial Relations, 58(4), 904-935. https://doi.org/10.1111/bjir.12528

Fernández-Reino, M., Sumption, M., \& Vargas-Silva, C. (2020). From low-skilled to key workers: The implications of emergencies for immigration policy. Oxford Review of Economic Policy, 36(Supplement_1), S382-S396.

https://doi.org/10.1093/oxrep/graa016

Ferroukhi, R., Lucas, H., Renner, M., Lehr, U., \& Breitschopf, B. (2013). Renewable Energy and Jobs. International Renewable Energy Agency (IRENA), 144.

Fitch-Roy, O., Albero, C., Barber, S., Hill, B., Gardner, P., Phillips, J., Azau, S., Casey, Z., Gagliardi, F., Koulouri, A., Moccia, J., Scola, J., Wilkes, J., \& Margoyles, A. (2013). Workers wanted: The EU wind energy sector skills gap. WindEurope.

https://doi.org/10.13140/RG.2.2.22454.55360

Friberg, J. H. (2012). Culture at work: Polish migrants in the ethnic division of labour on Norwegian construction sites. Ethnic and Racial Studies, 35(11), 1914-1933.

https://doi.org/10.1080/01419870.2011.605456

Fries-Tersch, E., Jones, E., \& Siöland, M. (2021). Annual Report on Intra-EU Labour Mobility 2020. https://ec.europa.eu/social/main.jsp?catld=738\&langld=en\&publd=8369

Fries-Tersch, E., Jones, M., Böök, B., \& Tugran, T. (2020). Annual Report on Intra-EU Labour Mobility 2019.

https://ec.europa.eu/social/main.jsp? catld=738\&langld=en\&publd=8242\&furtherPubs $=y$ es

Fries-Tersch, E., Tugran, T., \& Bradley, H. (2017). Annual Report on Intra-EU Labour Mobility 2016. https://op.europa.eu/en/publication-detail//publication/ddaa71cc-3e9a11e7-a08e-01aa75ed71a1/language-en 
Fries-Tersch, E., Tugran, T., Markowska, A., \& Jones, M. (2018). Annual Report on Intra-EU Labour Mobility 2018.

https://ec.europa.eu/social/main.jsp?catld=738\&langld=en\&publd=8174\&furtherPubs=y es

Fries-Tersch, E., Tugran, T., Rossi, L., \& Bradley, H. (2018). Annual Report on Intra-EU Labour Mobility 2017. https://op.europa.eu/en/publication-detail//publication/cd298a3cc06d-11e8-9893-01aa75ed71a1/language-en

Galgóczi, B., Leschke, J., \& Watt, A. (2016). EU Labour Migration in Troubled Times: Skills Mismatch, Return and Policy Responses (Vol. 1). Routledge.

Gambin, L., \& Hogarth, T. (n.d.). Employer Investment in Intermediate-level Stem Skills: How employer manage the investment risk associated with apprenticeships. Gatsby Foundation, 58.

Gambin, L., Hogarth, T., Murphy, L., Spreadbury, K., Warhurst, C., \& Winterbotham, M. (2016). Research to understand the extent, nature and impact of skills mismatches in the economy. 106.

Gambin, L., Hogarth, T., Winterbotham, M., Huntley-Hewitt, J., \& Eastwood, L. (2016). The apprenticeship levy: How will employers respond? Department for Education, Research Report, 111.

Gerards, R., Muysken, J., \& Welters, R. (2014). Active Labour Market Policy by a ProfitMaximizing Firm: Private Sector Initiated Employment Programme. British Journal of Industrial Relations, 52(1), 136-157. https://doi.org/10.1111/j.1467-8543.2012.00915.x

Geurts, N., \& Lubbers, M. (2017). Dynamics in intention to stay and changes in language proficiency of recent migrants in the Netherlands. Journal of Ethnic and Migration Studies, 43(7), 1045-1060. https://doi.org/10.1080/1369183X.2016.1245608

Gindele, N., Kaps, S., \& Doluschitz, R. (2016). Operational possibilities for dealing with the shortage of skilled labour in agriculture. Berichte ueber Landwirtschaft. 94(1).

https://buel.bmel.de/index.php/buel/article/view/89/Gindele.pdf

GIZ. (2018). Starke Unternehmerinnen für starke Frauen. Eine Initiative für geflüchtete Frauen. https://giz.berlin/projects/starke-unternehmerinnen-fuer-starke-frauen-eineinitiative-fuer-gefluechtete-frauen.htm

Glass, J., Dainty, A. R. J., \& Gibb, A. G. F. (2008). New build: Materials, techniques, skills and innovation. Energy Policy,36(12), 4534-4538.

https://doi.org/10.1016/j.enpol.2008.09.016 
Goh, E., \& Okumus, F. (2020). Avoiding the hospitality workforce bubble: Strategies to attract and retain generation $\mathrm{Z}$ talent in the hospitality workforce. Tourism Management Perspectives, 33, 100603. https://doi.org/10.1016/j.tmp.2019.100603

Goldner Lang, I. (2018). Intra-EU Mobility of EU Citizens and Third-Country Nationals: Where EU Free Movement and Migration Policies Intersect or Disconnect? In Research Handbook on EU Migration and Asylum Law.

https://poseidon01.ssrn.com/delivery.php?ID=809117069101030089086101119086022 0740000850370590210241240660970300090250900910001100600970370590600260 2009600712702812412310902508603001404701102612007201100509609001703509 5091106121069119025116093126100071126028119126077065031094069119001101 072003\&EXT $=$ pdf \&INDEX $=$ TRUE

Green, A. (2019). What is happening to middle skill workers? (OECD Social, Employment and Migration Working Papers No. 230; OECD Social, Employment and Migration Working Papers, Vol. 230). https://doi.org/10.1787/a934f8fa-en

Green, A. (2020). Employer decision-making around skill shortages, employee shortages and migration: Literature review. Institute for Employment Research, University of Warwick. Report commissioned by the Migration Advisory Committee.

Griesbeck, M. (2014). Erleichterung der Fachkräftezuwanderung durch rechtliche Regelungen und flankierende Massnahmen: Eine Zwischenbilanz.

Griesbeck, M. (2016). Erleichterung der Fachkräftezuwanderung durch rechtliche Regelungen und flankierende Massnahmen: Eine Zwischenbilanz.

Griffiths, P., Maruotti, A., Recio Saucedo, A., Redfern, O. C., Ball, J. E., Briggs, J., Dall'Ora, C., Schmidt, P. E., \& Smith, G. B. (2019). Nurse staffing, nursing assistants and hospital mortality: Retrospective longitudinal cohort study. BMJ Quality \& Safety, 28(8), 609-617. https://doi.org/10.1136/bmiqs-2018-008043

Hamdi, S., Silong, A. D., Binti Omar, Z., \& Mohd Rasdi, R. (2016). Impact of T-shaped skill and top management support on innovation speed; the moderating role of technology uncertainty. Cogent Business \& Management, 3(1), 1153768.

https://doi.org/10.1080/23311975.2016.1153768

Hassmiller, S. B., \& Cozine, M. (2006). Addressing The Nurse Shortage To Improve The Quality Of Patient Care. Health Affairs, 25(1), 268-274.

https://doi.org/10.1377/hlthaff.25.1.268

Healy, J., Mavromaras, K., \& Sloane, P. J. (2015). Adjusting to skill shortages in Australian SMEs. Applied Economics, 47(24), 2470-2487.

https://doi.org/10.1080/00036846.2015.1008764 
Heisler, W., \& Brandow, D. (2018). Retaining and engaging older workers: A solution to worker shortages in the U.S. Business Horizons, 61, 421-430.

Het Kenniscentrum Arbeidsmigranten. (2021). De resultaten van het 1e arbeidsmigrantenpanel. Een eerste onderzoek naar de woon-, werk-, en leefsituatie van arbeidsmigranten in Nederland. https://hetkenniscentrumarbeidsmigranten.nl/wpcontent/uploads/2021/04/De-resultaten-van-het-1e-arbeidsmigrantenpanel.pdf

Heyma, A., Bisschop, P., \& Biesenbeek, C. (2018). De economische waarde van arbeidsmigranten uit Midden- en Oost-Europa voor Nederland (SEO-Rapport No. 201837). SEO Economisch Onderzoek. https://www.seo.nl/publicaties/de-economischewaarde-van-arbeidsmigranten-uit-midden-en-oost-europa-voor-nederland/

Heyma, A., van der Werff, S., Berkhout, E., \& Hof, B. (2008). De economische impact van arbeidsmigratie uit de MOE-landen, Bulgarije en Roemenië (No. 2008-70; p. 91). SEO Economisch Onderzoek.

Ho, P. H. K. (2016). Labour and skill shortages in Hong Kong's construction industry. Engineering, Construction and Architectural Management, 23(4), 533-550.

https://doi.org/10.1108/ECAM-12-2014-0165

Hogarth, T. (n.d.). COVID-19 and the Demand for Labour and Skills in Europe: Early evidence and implications for migration policy. 22.

Hollywood, E., \& Mcquaid, R. W. (2007). Employers' Responses to Demographic Changes in Rural Labour Markets: The Case of Dumfries and Galloway. Local Economy: The Journal of the Local Economy Policy Unit, 22(2), 148-162.

https://doi.org/10.1080/02690940701390765

Hong, T., Pieke, F. N., Steehouder, L., \& van Veldhuizen, J. L. (2017). Dutch higher education and Chinese students in the Netherlands. 45.

Hooper, K. (2021). Achieving the "Partnership" in the European Union's Talent Partnerships. Migration Policy Institute. https://www.migrationpolicy.org/news/europeanunion-talent-partnerships

Houwerzijl, M., \& Schrauwen, A. (2018). From Competing to Aligned Narratives on Posted and Other Mobile Workers within the EU? In Towards a Decent Labour Market for Low-Waged Migrant Workers (pp. 81-108). Amsterdam University Press.

IDW. (n.d.a). Betaling. https://www.idw.nl/nl/betaling.html

IDW. (n.d.b). Werken. https://www.idw.nl/nl/naar-NL-werken.html 
ILO. (2018). Guidelines concerning measurement of qualifications and skills mismatches of persons in employment. International Labour Office, Department of Statistics.

ILO. (n.d.). Labour Migration in Asia and the Pacific. Retrieved from:

https://www.ilo.org/asia/areas/labour-migration/WCMS 634559/lang--en/index.htm

ILO, \& CEDEFOP. (2011). Skills for green jobs. A global view. International Labour Office, Skills and Employability Department.

ILO, \& European Commission. (2011). Skills and Occupational Needs in Renewable Energy. International Labour Office, Skills and Employability Department.

ILO. (2018). Recognition of Prior Learning (RPL). Learning Package. International Labour Office, Skills and Employability Branch / Employment Policy Department.

IMF. (2019). Demographic Headwinds in Central and Eastern Europe (Departmental Paper Series). https://www.imf.org/en/Publications/Departmental-Papers-PolicyPapers/Issues/2019/07/11/Demographic-Headwinds-in-Central-and-Eastern-Europe46992

Ing, D. (2008). T-shaped Professionals, T-shaped Skills, Hybrid Managers. [Web blog post.]. Coevolving Innovations.

IOM. (2019). Glossary on Migration.

https://publications.iom.int/system/files/pdf/iml 34 glossary.pdf

IOM. (2021a). MATCH, Hiring African Talents. IOM Netherlands. https://iomnederland.nl/en/migrant-inclusion/match

IOM. (2021b). MATCH information sheet. https://iomnederland.nl/images/Match/MATCH Flyer nl.pdf

Jacob, E. R., McKenna, L., \& D'Amore, A. (2015). The changing skill mix in nursing: Considerations for and against different levels of nurse. Journal of Nursing Management, 23(4), 421-426. https://doi.org/10.1111/jonm.12162

Jacobsson, S., \& Karltorp, K. (2012). Formation of competences to realize the potential of offshore wind power in the European Union. Energy Policy, 44, 374-384.

https://doi.org/10.1016/j.enpol.2012.01.069

Jagger, N., Foxon, T., \& Gouldson, A. (2013). Skills constraints and the low carbon transition. Climate Policy, 13(1), 43-57. https://doi.org/10.1080/14693062.2012.709079 
Jeon, S. (2019). Unlocking the Potential of Migrants: Cross-country Analysis. OECD. https://doi.org/10.1787/045be9b0-en

Kalantaryan, S., Mazza, J., Scipioni, M., Europäische Kommission, \& Gemeinsame Forschungsstelle. (2020). Meeting labour demand in agriculture in times of COVID 19 pandemic. https://doi.org/10.2760/686549

Kall, K., Lillie, N., Matuszczyk, K., \& Salamońska, J. (2020). Regional study from Ukraine to Finland and Estonia via Poland: Migration and posting of third country nationals. University of Jyväskylä; University of Warsaw.

Kasnauskiene, G., \& Michnevic, K. (2017). Contribution of increased life expectancy to economic growth: Evidence from CEE countries. International Journal of Economic Sciences, 6(2), 82-99.

Khoudja, Y. (2018). Employment and Education-Occupation Mismatches of Immigrants and their Children in the Netherlands: Comparisons with the Native Majority Group. Social Inclusion, 6(3), 119-141. https://doi.org/10.17645/si.v6i3.1452

Kimmell, J., \& Martin, S. A. (2015). Sorting out the Skills Gap: Analyzing the Evidence for a Shortage of Middle-Skill Workers in the Manufacturing and Healthcare Industries in the Portland Region. Institute of Portland Metropolitan Studies, 123, 35.

Kodoth, P., \& Jacob, T. K. (2013). International Mobility of Nurses from Kerala (India) to the EU: Prospects and Challenges with special reference to the Netherlands and Denmark. European University Institute, 53.

Koolmees, W. (2021). Kamerbrief over de regeling voor gespecialiseerde koks voor de Aziatische horecasector.

https://www.rijksoverheid.nl/documenten/kamerstukken/2021/06/04/tk-brief-aanpassingvan-de-regeling-voor-de-aziatische-horecasector

Kremer, M. (2020). A 'better work' strategy is necessary for resilient societies and economies. European University Institute, N.4.

Kroes, J. A., \& van Oort, H. (2020). Netherlands. In The Corporate Immigration Review (10th ed.). Law Business Research Ltd, London, UK.

https://thelawreviews.co.uk/title/the-corporate-immigration-review

Kroezen, M., Schäfer, W., Sermeus, W., Hansen, J., \& Batenburg, R. (2018).

Healthcare assistants in EU Member States: An overview. Health Policy, 122(10), 1109-1117. https://doi.org/10.1016/j.healthpol.2018.07.004 
Kwon, O. (2019). The diverging paths of skilled immigration in Singapore, Japan and Korea: Policy priorities and external labor market for skilled foreign workers. Asia Pacific Journal of Human Resources, 57(4), 418-444. https://doi.org/10.1111/1744-7941.12173

Lens, D., Mussche, N., \& Marx, I. (2021). A hole in the wall of fortress Europe: The trans-European posting of third-country labour migrants. International Migration. https://doi.org/10.1111/imig.12867

Lewis, P. (2013). Technician Roles, Skills and Training in the UK Chemical Industry: An Analysis. 48.

Lichy, J., \& Khvatova, T. (2019). Rethinking solutions for re-balancing the education-job mismatch. Journal of Management Development, 38(9), 733-754.

https://doi.org/10.1108/JMD-03-2018-0070

Liebig, T., \& Tronstad, K. R. (2018). Triple Disadvantage? A first overview of the integration of refugee women (No. 216; OECD Social, Employment and Migration Working Papers). OECD. https://www.oecd-ilibrary.org/docserver/3f3a9612en.pdf?expires=1623415940\&id=id\&accname=guest\&checksum=4A767559E263014DF B1167D8016E5891

Lucas, H., Pinnington, S., \& Cabeza, L. F. (2018). Education and training gaps in the renewable energy sector. Solar Energy, 173, 449-455.

https://doi.org/10.1016/j.solener.2018.07.061

Lyons, H., Taylor, A., \& Green, A. (2020). Rising to the UK's Skills Challenge. Industrial Strategy Council, 53.

Make It In Germany. (n.d.). Information on the Skilled Immigration Act. Information on the Skilled Immigration Act. Retrieved 8 April 2021, from https://www.make-it-ingermany.com/en/visa/skilled-immigration-act

Malamatenios, C. (2016). Renewable energy sources: Jobs created, skills required (and identified gaps), education and training. Renewable Energy and Environmental Sustainability, 1, 23. https://doi.org/10.1051/rees/2016038

Marchant, K., Fajth, V., \& Siegel, M. (2019). Relevant Data to Understand Migration in the EU (REMINDER Project). https://www.reminder-project.eu/wpcontent/uploads/2019/11/D2.5-1.pdf

Marriott, J., \& Moore, N. (2014). NHBC Foundation: Improving recruitment of young people into home building. University of Derby, 51. 
Marx, I., \& Schouteten, R. (2020). Arbeidsmigranten in Nederland en België. Tijdschrift Voor Arbeidsvraagstukken, 36(2), 115-117.

Mayer, M., \& Clemens, M. (2021). Fachkräftemigrationsmonitor.

https://www.bertelsmann-

stiftung.de/fileadmin/files/Projekte/Migration fair gestalten/IB Fachkraeftemigrationsmo nitor 2021.pdf

McCollum, D., \& Apsite-Berina, E. (2015). Recruitment through migrant social networks from Latvia to the United Kingdom: Motivations, processes and developments. Migration Letters, 12(2), 50-66. https://doi.org/10.33182/ml.v12i1.256

McCollum, D., \& Findlay, A. (2018). Oiling the wheels? Flexible labour markets and the migration industry. Journal of Ethnic and Migration Studies, 44(4), 558-574.

https://doi.org/10.1080/1369183X.2017.1315505

McGuire, D., Polla, G., \& Heidl, B. (2017). Unlocking hospitality managers career transitions through applying Schein's career anchors theory. European Journal of Training and Development, 41(7), 578-592. https://doi.org/10.1108/EJTD-04-2016-0022

McKinsey Global Institute. (2020). The future of work in Europe. 52.

Menz, G. (2011). Employer Preferences for Labour Migration: Exploring 'Varieties of Capitalism'-Based Contextual Conditionality in Germany and the United Kingdom. The British Journal of Politics and International Relations, 13(4), 534-550.

https://doi.org/10.1111/j.1467-856X.2011.00451.x

Migrant Women Association Malta. (n.d.). What we do.

https://migrantwomenmalta.org/what-we-do/

Migration Advisory Committee (MAC). (2020). Review of the Shortage Occupation List: 2020.

https://assets.publishing.service.gov.uk/government/uploads/system/uploads/attachmen $\mathrm{t}$ data/file/927352/SOL 2020 Report Final.pdf

Monicca, M. D., Cassim, N., \& Karodia, A. M. (2016). The Effectiveness Of Clinical Associates In Addressing The Human Resources Challenge Of Skills Shortage: A Case Study Of Tshwane District Hospital (South Africa). 10, 39.

Morris, A., \& Donovan, P. (2019). Bridging the skills gap: Apprentice assistant practitioners having an impact in mental healthcare services. British Journal of Healthcare Assistants, 13(9), 452-457. https://doi.org/10.12968/bjha.2019.13.9.452 
Mortera-Martinez, C., \& Oppenheim. (2018). Why Europe needs legal migration and how to sell it. https://www.cer.eu/publications/archive/policy-brief/2018/why-europeneeds-legal-migration-and-how-sell-it

Muller, J., Beckers, P., \& Pijpers, R. (2017). Recognising the Skills and Competencies of Non-EU Foreign Nationals: A Case Study of the Healthcare Sector in the Netherlands. Social Policy and Society, 16(4), 681-691. Cambridge Core. https://doi.org/10.1017/S1474746417000264

Mussche, N., \& Lens, D. (2019). The ECJ's Construction of an EU Mobility RegimeJudicialization and the Posting of Third-country Nationals. JCMS, 57(6), 1247-1261. https://doi.org/10.1111/jcms.12891 (c) 2019

Myklebust, J. P. (2018). Pact to attract 10,000 more STEM candidates by 2025. https://www.universityworldnews.com/post.php?story=20180504134544837

Nationaal Kenniscentrum EVC. (n.d.). EVC versterkt positie op arbeidsmarkt. http://www.nationaal-kenniscentrum-evc.nl/

NHS. (2020). NHS International recruitment toolkit.

NIDI \& CBS. (2021). Eindrapport Verkenning Bevolking 2050 Bevolking 2050 in beeld: Opleiding, arbeid, zorg en wonen. https://nidi.nl/nl/nieuws events/bevolking-2050-inbeeld/

Novitz, T., \& Andrijasevic, R. (2020). Reform of the Posting of Workers Regime - An Assessment of the Practical Impact on Unfree Labour Relations. JCMS, 58(5), 13251341. https://doi.org/10.1111/jcms. 13033

OECD. (2011). Recruiting Immigrant Workers: Sweden 2011. OECD. https://doi.org/10.1787/9789264167216-en

OECD. (2016). Labour migration in Asia: Building effective institutions.

OECD. (2017). Getting Skills Right: Skills for Jobs Indicators. OECD. https://doi.org/10.1787/9789264277878-en

OECD. (2018a). German Policy Brief: Using Migration to Meet Skills Shortages. https://www.oecd.org/germany/Germany-policy-brief-migration.pdf

OECD. (2018b). Using migration to meet skills shortages.

OECD. (2020a). How attractive is Germany for foreign professionals? (No. 23; Migration Policy Debates). OECD. 
OECD. (2020b). Skills proficiency and the labor-market outcomes of immigrants. OECD - Adults Skills in Focus.

OECD \& International Labour Organization. (2017). Engaging Employers in Apprenticeship Opportunities: Making It Happen Locally. OECD.

https://doi.org/10.1787/9789264266681-en

Oomes, N., Dietz, T., \& Duvell, F. (2019). Dutch labour market shortages and potential labour supply from Africa and the Middle East: Is there a Match? SEO Amsterdam Economics.

Oosterhoff, I. (2020, September 9). 'Ik denk dat niemand mij zal bellen'. De Groene Amsterdammer, nr. 37. https://www.groene.nl/artikel/ik-denk-dat-niemand-mij-zal-bellen

Pan, W., Chen, L., \& Zhan, W. (2019). PESTEL Analysis of Construction Productivity Enhancement Strategies: A Case Study of Three Economies. Journal of Management in Engineering, 35(1), 05018013. https://doi.org/10.1061/(ASCE)ME.1943-5479.0000662

Parusel, B., \& Tamas, K. (2016). The most open system for labour immigration - has it worked? Migration Policy Practice, 6(1), 11-15.

PBL. (2019). Verkenning bevolking 2050 Zekerheden en onzekerheden over de gevolgen van veranderingen in de bevolking.

Peiró, T., Lorente, L., \& Vera, M. (2020). The COVID-19 Crisis: Skills That Are Paramount to Build into Nursing Programs for Future Global Health Crisis. International Journal of Environmental Research and Public Health, 17(18), 6532.

https://doi.org/10.3390/ijerph17186532

Pitukhina, M., Tolstoguzov, O., \& Radikov, I. (2020). Migrants' strategies within the Arctic Council member-states: Bottleneck vacancies analysis (by the example of Finland, Sweden, Denmark and Norway). IOP Conference Series: Earth and Environmental Science, 539, 012116. https://doi.org/10.1088/1755-1315/539/1/012116

Rahim, A., Rayp, G., \& Ruyssen, I. (2021). Circular Migration: Triple Win or Renewed Interests of Destination Countries? Ghent University.

Ratuva, S. (Ed.). (2020). New Middle-Class Labor Migrants. In The Palgrave Handbook of Ethnicity. Springer Singapore. https://doi.org/10.1007/978-981-13-0242-8

Recognition in Germany. (n.d.). Skilled Im-mi-gra-tion Act. Skilled Im-mi-gra-tion Act. https://www.anerkennung-in-deutschland.de/html/en/pro/skilled-immigration-act.php\# 
Refugees Women's Association. (n.d.). Our services.

https://refugeewomen.org.uk/Aboutus\%20/services

Reinold, J. (Forthcoming). The perceived impact of COVID-19 on the employment of (international) workers at Dutch SMEs.

Researchcentrum voor Onderwijs en de Arbeidsmarkt. (n.d.).

Arbeidsmarktinfomatiesysteem (AIS). https://roa.nl/research/research-projects/projectonderwijs-arbeidsmarkt-poa

Researchcentrum voor Onderwijs en Arbeidsmarkt. (2019). De arbeidsmarkt naar opleiding en beroep tot 2024. https://ideas.repec.org/p/unm/umarep/2019007.html

Richards-Carpenter, N. N. (2016). The Study of Survival and Resilience of the Mature East-Midlands Textile and Clothing Industrial Cluster in United Kingdom. Economy \& Business, 10, 14.

Riley, R., \& et al. (2020). Professional \& Business Services sector. Creating further demand and growth outside London.

Rogoz, M., \& Perchinig, B. (2019). Intra-EU Mobilities: Perceived Impacts (REMINDER Project). ICMPD. https://www.understandfreemovement.eu/wp-

content/uploads/2020/01/D6.5.pdf

Ruhs, M., \& Anderson, B. (2010). Who Needs Migrant Workers? Oxford University Press. https://doi.org/10.1093/acprof:oso/9780199580590.001.0001

Rutovitz, J., \& Atherton, A. (2009). Energy Sector Jobs to 2030: A Global Analysis. Final report version 2-Prepared for Greenpeace International. Institute for Sustainable Futures - University of Technology, Sydney.

Saes, L., \& van der Veen, G. (2019). Eco-Innovation in the Netherlands. EIO Country Profile. 2018-2019. Eco-Innovation Observatory.

https://ec.europa.eu/environment/ecoap/country profiles en

Saner, R., Yiu, L., \& Rush, L. (2019). Population ageing and a lack of semi-skilled workers in Switzerland: Opportunities for refugees? Career Development International, 25(1), 24-31. https://doi.org/10.1108/CDI-11-2018-0275

Schäfer, W., Kroezen, M., Hansen, J., Sermeus, W., Aszalos, Z., \& Batenburg, R. (2016). Core Competences of Healthcare Assistants in Europe (CC4HCA). European Commission, 98. 
Schultz, C., \& Rijks, B. (2014). Mobility of Health Professionals to, from and within the European Union. UN. https://doi.org/10.18356/97918393-en

Sharma, K., Oczkowski, E., \& Hicks, J. (2016). Skill shortages in regional Australia: A local perspective from the Riverina. Economic Analysis and Policy, 52, 34-44.

https://doi.org/10.1016/j.eap.2016.08.001

She Matters. (n.d.). She Matters Recruitment. Shematters.NI. https://www.shematters.nl

Shirmohammadi, M., Beigi, M., \& Stewart, J. (2019). Understanding skilled migrants' employment in the host country: A multidisciplinary review and a conceptual model. The International Journal of Human Resource Management, 30(1), 96-121.

https://doi.org/10.1080/09585192.2018.1511615

Siegel, M., Marchand, K., Nazarov, I., Wagner, V., \& Belukova, E. (2017). Determination of the Demand for Foreign Labour Force in the Labour Market of Azerbaijan. ICMPD; Mobilaze.

Siegel, M., \& van der Vorst, V. (2012). Evaluation of the 'Blue Birds' Circular Migration Pilot in The Netherlands. Maastricht Graduate School of Governance (MGSoG).

Simic, S., \& Wormann, H. (2015). Arbeidsmarkttekorten en migratie: Het vaststellen van arbeidsmarkt- tekorten en de behoefte aan arbeidsmigratie van derdelanders in Nederland. Europees Migratienetwerk.

https://www.tilburguniversity.edu/sites/default/files/download/arbeidsmarkttekorten\%20e n\%20migratie\%20emn 2.pdf

Skevi, A., Szigeti, H., Perini, S., Oliveira, M., Taisch, M., \& Kiritsis, D. (2014). Current Skills Gap in Manufacturing: Towards a New Skills Framework for Factories of the Future. In E. Bayro-Corrochano \& E. Hancock (Eds.), Progress in Pattern Recognition, Image Analysis, Computer Vision, and Applications (Vol. 8827, pp. 175-183). Springer International Publishing. http://link.springer.com/10.1007/978-3-662-44739-0 22

Smits, W., \& Zwick, T. (2004). Why do business service firms employ fewer apprentices?: A comparison between Germany and The Netherlands. International Journal of Manpower, 25(1), 36-54. https://doi.org/10.1108/01437720410524983

Sooriyaarachchi, T. M., Tsai, I.-T., El Khatib, S., Farid, A. M., \& Mezher, T. (2015). Job creation potentials and skill requirements in, PV, CSP, wind, water-to-energy and energy efficiency value chains. Renewable and Sustainable Energy Reviews, 52, 653668. https://doi.org/10.1016/j.rser.2015.07.143

Stark im Beruf. (n.d.). Programm. Starkimberuf.De. https://www.starkimberuf.de 
Stephany, F. (2021). One size does not fit all: Constructing complementary digital reskilling strategies using online labour market data. Big Data \& Society, 8(1), 205395172110031. https://doi.org/10.1177/20539517211003120

Susskind, D., \& Vines, D. (2020). The economics of the COVID-19 pandemic: An assessment. Oxford Review of Economic Policy, 36(Supplement_1), S1-S13. https://doi.org/10.1093/oxrep/graa036

SZW. (2021). Rapport arbeidsmigranten.

https://www.rijksoverheid.nl/documenten/rapporten/2021/01/22/bijlage-1-rapportarbeidsmigranten

Techniek Nederland. (2019). Economische vooruitzichten 2020 en verder. Techniek Nederland.

Thalassinos, E., Cristea, M., \& Georgiana Noja, G. (2019). Measuring active ageing within the European Union: Implications on economic development. Equilibrium. Quarterly Journal of Economics and Economic Polic, 14(4), 591-609.

https://doi.org/10.24136/eq.2019.028

The Expert Council's Research Unit (SVR Research Unit), \& Migration Policy Institute Europe. (2019). Legal migration for work and training: Mobility options to Europe for those not in need of protection (No. 2). The Expert Council of German Foundations on Integration and Migration/MPI Europe.

Tjadens. (2011). The Netherlands: Mobility of Health Professionals. Health and Social Care Associates (HASCA)

Tūtlys, V., \& Spöttl, G. (2021). Disruption of qualifications in manufacturing: Challenges and prospects. European Journal of Training and Development, ahead-of-print(aheadof-print). https://doi.org/10.1108/EJTD-07-2020-0121

UWV. (2018). Moeilijk vervulbare vacatures Oplossingen uit de praktijk. 28 juni. https://www.uwv.nl/overuwv/Images/moeilijk-vervulbare-vacatures-oplossingen-uit-depraktijk.pdf

UWV. (2020). Kansrijke beroepen Landelijk overzicht van beroepen december 2020. https://www.werk.nl/imagesdxa/kansrijke beroepen december 2020 tcm95425307.pdf

UWV. (2021a). Verwachtingen werkgevers voor 2021, Indicatie uit werkgeversenquête UWV 1 april 2021.

https://www.werk.nl/imagesdxa/verwachtingen werkgevers voor 2021 tcm95-

427707.pdf 
UWV. (2021b). Impact coronacrisis op werk en werving: Ervaringen werkgevers. 2 februari.

https://www.werk.nl/arbeidsmarktinformatie/arbeidsmarkt/ontwikkelingen/coronacrisis/lm pact-coronacrisis-op-werk-en-werving-ervaringen-werkgevers/

Van den Tillaart, H., \& Aalders, P. (2019). TI-branche en TI-beroepen. Analyse en rapportage op basis van onderzoek onder weknemers en wekrgevers.

Van Loo, J., De Grip, A., \& Lintjens, E. (2007). Dynamiek in Metalektro vereist innovatief HR-beleid.

Vargas-Silva, C. (2019). Summary Report: Insights on the Determinants of Mobility within the EU (H2020 REMINDER). Centre on Migration, Policy and Society, University of Oxford. https://www.understandfreemovement.eu/wpcontent/uploads/2020/01/D3.5.pdf

Vermeulen, H., den Boer, P., Verhaegh, T., van der Horst, J., \& Rossen, L. (2018). Trends en ontwikkelingen in de technische installatiebranche 2018 Bedrijvigheid, arbeidsmarkt en beroepsopleiding in de periode tot 2022. KBA Nijmegen.

Vollmer, M. (2015). Determining Labour Shortages and the need for Labour Migration in Germany: Focus-Study by the German National Contact Point for the European Migration Network (EMN) (Working Paper No. 76). Federal Office for Migration and Refugees.

Walsh, P. W. (2021). The UK's 2021 points-based immigration system. Migration Observatory policy primer. COMPAS, University of Oxford.

Westerhuis, A., Smulders, H., \& Cox, A. (2020). International mobility in apprenticeships: Focus on long-term mobility: Netherlands. Cedefop ReferNet thematic perspectives series.

http://libserver.cedefop.europa.eu/vetelib/2019/international mobility apprenticeship N et herlands Cedefop ReferNet.pdf

Westert, G. P. (2010). Dutch Health Care Performance Report 2010,. National Institute for Public Health and Environment.

Weterings, A., Bakens, J., Ivanova, O., \& Fouarge, D. (2019). Frictie op de arbeidsmarkt door de energietransitie: Een modelverkenning. $P B L \& R O A, 49$.

https://www.pbl.nl/sites/default/files/downloads/pbl-2019-frictie-op-de-arbeidsmarktdoor-de-energietransitie-3438.pdf 
Weyman, A. K., Roy, D., \& Nolan, P. (2019). One-way pendulum?: Staff retention in the NHS: determining the relative salience of recognised drivers of early exit. International Journal of Workplace Health Management, 13(1), 45-60.

https://doi.org/10.1108/IJWHM-06-2019-0084

Winterbotham, M., Vivian, D., Kik, G., Huntley, J., Tweddle, M., Downing, C., Thomson, D., Morrice, N., \& Stroud, S. (2018). Employer skills survey 2017. 227.

Wright, C. F., \& Constantin, A. (2021). Why recruit temporary sponsored skilled migrants? A human capital theory analysis of employer motivations in Australia. Australian Journal of Management, 46(1), 151-173.

https://doi.org/10.1177/0312896219895061

Zubir, M. Z. M., Lai, C. S., Zaime, A. F., M.F. Lee, Ibrahim, B., \& Ismail, A. (2021).

Dimension of Green Skills: Perspectives from the Industry Experts. Journal of Technical Education and Training, 13(1), 159-166. 


\section{Annex 1: Search terms}

Table A.1: Search terms for literature review

\begin{tabular}{|c|c|}
\hline Broader topic & Search terms ${ }^{*}$ \\
\hline $\begin{array}{l}\text { Strategies to mitigate } \\
\text { labour shortages }\end{array}$ & $\begin{array}{l}\text { - Address/ fill/ mitigate/ alleviate/ meet/ match labour/ labour market/ } \\
\text { staffing/ skills/ employee shortages/ gaps/ demand/ bottlenecks } \\
\text { - Address/ fill/ mitigate/ alleviate/ meet/ match MBO level 4/ upper } \\
\text { secondary vocational level/ middle segment/ vocational education } \\
\text { and training/ VET/ occupations/ hard-to-fill vacancies }\end{array}$ \\
\hline $\begin{array}{l}\text { Migration as a strategy } \\
\text { to mitigate labour } \\
\text { shortages }\end{array}$ & $\begin{array}{l}\text { - Employ/ recruit/ hire/ attract migrants/ migrant workers/ foreign } \\
\text { workers/ international workers/ migrant employees/ foreign } \\
\text { employees/ international employees/ migrant personnel/ foreign } \\
\text { personnel/ international personnel/ labour migrants to mitigate/ meet/ } \\
\text { match/ alleviate/ address/ fill labour/ labour market/ staffing/ skills/ } \\
\text { employee shortages/ gaps/ demand/ bottlenecks/ hard-to-fill } \\
\text { vacancies at MBO level 4/ upper secondary vocational level/ middle } \\
\text { segment/ vocational education and training/ VET }\end{array}$ \\
\hline Related policy & 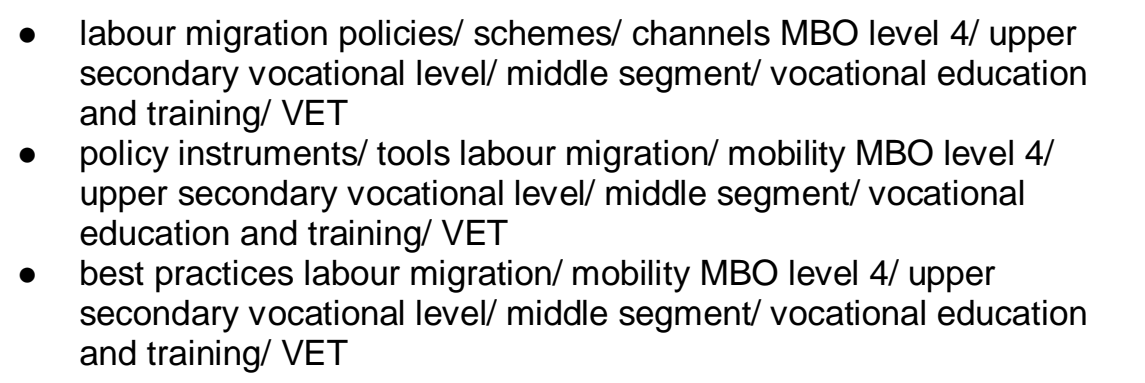 \\
\hline * & $\begin{array}{l}\text { All search terms have been combined with the focus sectors and main } \\
\text { occupations: } \\
\text { - Metal sector/ metal industry } \\
\circ \text { Mechanical engineers } \\
\circ \quad \text { Maintenance engineers } \\
\text { - Energy transition } \\
0 \text { Electrical engineers } \\
\circ \quad \text { Electricians } \\
\circ \quad \text { Electronic mechanics } \\
\text { - Healthcare sector } \\
\circ \text { Nurses } \\
\circ \text { Medical support staff }\end{array}$ \\
\hline
\end{tabular}




\section{Annex 2: Future technical and green skills in the Machine tool industry}

Table A.2: Future technical skills for the Machine tool industry

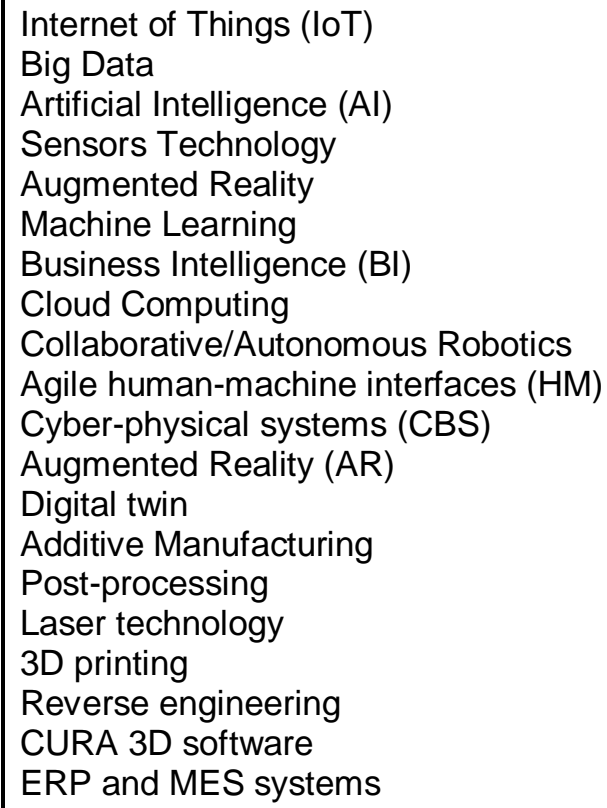

Source: Retrieved and readapted from Akyazi et al. (2020) 
Table A.3: Future green skills for the Machine tool industry

Environmental awareness

Energy efficiency

Platforms for energy management of equipment and plants

Monitoring systems of energy consumption

Sustainable resource management

Waste reduction and waste management

Water conservation

Resource reuse/recycling

Knowledge and understanding of international and national standards and legislation

Product life cycle impact assessment

Circular economy

Climate change risk management

Source: Retrieved and readapted from Akyazi et al. (2020) 